\title{
Recurring Lexis and Reader-Reception in Horace's Odes The Formation of a Lyric Opus
}

\author{
by
}

\section{Colin Anderson}

\author{
A thesis prepared in fulfilment of the requirements for the \\ degree of Master of Arts in Classics at Victoria University of \\ Wellington, \\ July 2014.
}


ABSTRACT

\section{Recurrent Lexis and Reader-Reception in Horace's Odes The Formation of a Lyric Opus}

This study investigates perceived patterns of lexical recurrence in consecutive or closely proximate poems in Books 1-3 of the Odes of the Roman poet Horace and considers the significance these may have for the structure and organization of this work and its interpretive reception by readers.

An initial discussion and demonstration of the types of lexical recurrence observed and their frequency prompts the question of the extent to which these recurrent lexical usages are intentional on the part of the author and hence whether they were factors in determining the order in which the poems of each book are arranged. This question is investigated firstly through statistical analysis, which shows that there is no statistically significant greater clustering effect apparent in the lexical patterns observed than had the odes been arranged in random order.

Nevertheless, given than certain recurrences between closely adjacent poems do stand out because of the identity or close similarity of their grammatical or morphological forms and/or metrical location, and that this phenomenon has been perceived by other commentators, the significance that might be attributed to these as poetic effects falls within the domain of reader-reception theory. A summary review of the principal tenets of this theory as developed especially by Ingarden, Gadamer, Jauss and Iser is undertaken in order to derive a sound theoretical method by which the recurrence patterns may be analysed and coherent meaning may be constructed from them. This method is then applied to analysis of a prominent cluster of lexical recurrences over the final five poems of Odes 1 (1.34-1.38). 
The question of how far such meaning may have corresponded to the intentions of the author Horace is then addressed. A distinction is made, following Bakhtin, between the "primary", historical author who composed the work and the "secondary" authorial consciousness who engages the reader through the text. While intentions of the former are ultimately unknowable, the secondary author "Horace" does declare intentions for his work through his texts which the reader may then reconstruct.

The thesis posits that the poetic ambition of Horace within this textual horizon was first to acquire an erudite and discerning audience capable of accepting him and appreciating his artistry, and then to develop a distinctive generic vehicle by which to engage this audience in dialogue about matters of importance in the Roman social, political and cultural worlds. The development of an audience is a major theme of his Satires Book 1, while the book of Epodes is the framework for his attempt to adapt the iambic metre of Archilochus to his dialogic purpose. The analysis shows that this latter project proved unfruitful because of the indelible association of iambic with invective.

The concluding chapter shows that it was the adoption of archaic Greek lyric metres other than iambic that finally provided Horace with the poetic vehicle he sought to write verse that both adhered to the Callimachean aesthetic of brevity and technical perfection and allowed engagement with serious as well as frivolous themes. It examines the manner by which the three Books of Odes, read sequentially as a single opus, firstly familiarize their readers with these archaic metres and the range of lyric themes they can encompass before leading them to an acceptance that lyric can also address important public issues, notably in the "Roman Odes" of Book 3. The perception of the patterns of lexical recurrence throughout the three books is a significant factor in promoting this dialogic engagement of the reader with the text. 


\section{ACKNOWLEDGEMENTS}

I wish to acknowledge the inestimable assistance, guidance and support I have received from the following people and institutions in the preparation of this thesis:

Dr Simon Perris, Senior Lecturer in Classics at Victoria University of Wellington who supervised my study, for the very high quality of his scholarly advice, his meticulous checking of my draft texts, and his supportive enthusiasm for the project.

The staff and graduate students of the School of Classics at Victoria University for welcoming me into their midst and for enabling me to be part of a very active circle of researchers into a wide range of fields in Classical Studies.

My very old friend Dr Ray Littler, now Honorary Fellow in the Department of Statistics at the University of Waikato, who provided me with expert statistical analysis of the patterns of lexical recurrence in the Odes, assisted by the technical services of his department.

The lending and inter-loan services of the libraries of Massey University and Victoria University.

My dear wife Maureen, who has constantly supported and encouraged me during my year's study, patiently indulging my hobby when I might have spent more time sharing my retirement days with her. 


\section{Recurrent Lexis and Reader-Reception in Horace's Odes The Formation of a Lyric Opus}

\section{Table of Contents}

Introduction .............................................................................. 1

Chapter 1: Patterns of Repetition in the Odes f................................ 6

Chapter 2: Author-Intention and Reader-Reception ....................... 21

Chapter 3: The Development of an Audience ................................... 44

Chapter 4: The Search for a Poetic Form .......................................... 60

Chapter 5: The Construction of a Lyric Opus ................................. 78

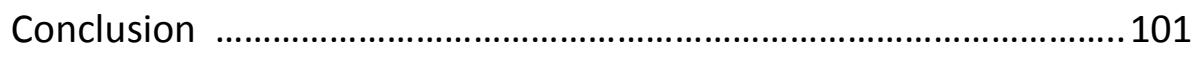

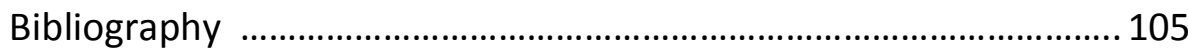

Electronic Appendices (on CD): three Excel spreadsheet files labelled Odes 1, Odes 2 and Odes 3, presenting the full texts of the three books, lists of the defined significant lexis, a table of the lexical recurrences across the odes of each book and a table of these patterns. 


\section{Recurring Lexis and Reader-Reception in Horace's Odes \\ The Formation of a Lyric Opus}

\section{Introduction}

This thesis arose out of observations I made while undertaking a translation into English of Book 1 of the Odes of Horace. ${ }^{1}$ The translations were made following the standard order of the poems, which is generally recognized to have been determined by the poet himself $^{2}$ at the moment of their first publication in a composite three-volume opus in 23 $\mathrm{BCE} .^{3}$ The close reading of the Latin texts that the translation demanded brought to my attention a pattern of word repetitions that emerged across sequences or clusters of adjacent poems before, in many cases, either not being used again, or only infrequently thereafter, over the rest of the book.

Further investigation has shown that such patterns of recurrence are also significantly present in Books 2 and 3. The repetitions stand out all the more prominently in that they frequently occur between poems that are quite different in genre, theme, content and length. Such variatio is indeed a well-attested characteristic of the whole Odes collection.

These observations therefore raised for me the question of whether such patterns were intentional poetic devices employed by the author or whether, to the contrary, they are just fortuitous effects little different from what might result from any random ordering of the collection.

Harvesting the Day. Horace for the $21^{\text {st }}$ Century (Wellington, 2010).

2 Collinge, (1961) 36, affirmed: "In the main it is not questioned that we have the poems in their original ordering, and that it was Horace who placed them so".

3 Nisbet \& Hubbard (1978) 1, 151-156. The date of 23 BCE for the whole collection is contested by Hutchinson (2008) 131ff., who argues that Odes 1-3 were published separately and sequentially, Book 1 in 26, Book 2 in early 24 and Book 3 in early 23. This view, however, has gained little acceptance. 
In either case, though, the repetitions are demonstrably present. They therefore present a challenge to the general interpretation of the whole three-book opus of the Odes, in that they raise the question of how the collection should be read and the extent to which individual poems relate to those adjacent to them. Now it can be safely asserted that, given the physical limitations of the ancient papyrus book-roll, readers were almost certainly obliged to read sequentially poems that were published in such a format. In this way, the opportunities for recalling an immediately preceding or closely proximate prior usage of a particular lexical form would be enhanced over any simple separate reading of the poems they occurred in, especially if the words were identical or closely related in grammatical form, or appeared at significantly marked positions within the poems or their respective lines of verse. This effect would be further enhanced where the recurrences were numerous between poems or frequent over a series of poems. It can therefore be argued that such recollections, by bringing a reader's attention back to a prior poem, then invite the reader to interpret individual odes not solely in terms of their own generic and thematic content, but also as refracted through the hermeneutic prism of other poems collated in close proximity.

As a result, my project aims to explore the construction of the whole lyric opus of the Odes 1-3 in order to investigate the function of individual poems within the greater order. This will necessarily involve consideration of authorial intention, not only of the ordering of the 88 odes of the collection, which established scholarship takes as a given, but also in the way in which the poems might be read in relation to each other. This in turn will lead to a consideration of the audience that Horace sought to cultivate and develop for his work, the elaboration of an appropriate poetic vehicle for his purpose, and the way the Odes collection was ultimately constructed in order to fulfil his poetic ambitions.

Chapter 1 presents evidence of the patterns of lexical repetition across the three books of the Odes. (A comprehensive presentation of all such occurrences from Books 1-3 is included in the electronic appendices to the thesis, along with associated statistical information.) This is followed by a statistical analysis of Book 1 which assesses whether such lexical repetitions differ significantly from what would be expected from any 
random distribution of the odes in this Book. The conclusion reached is that, within the broad parameters set for this analysis, no significant difference can be discovered.

Chapter 2 addresses the consequences of this finding for the interpretation of the apparent repetitions. This issue will be discussed generally within the framework of reader-reception theory. Out of this discussion, I derive a theoretical position which asserts that the patterns of lexical repetition that an attentive reader may perceive between adjacent or proximate poems set up a hermeneutic dialogue between the text and the reader through which multiple layers of meaning may be realized. In this way, an interconnected and multi-faceted fabric of meaning may be constructed which will illuminate both each individual ode within the collection as well as the deep-level texture of the three-book lyric opus as a whole. The chapter concludes with a close analysis of the pattern of repetitions revealed across the sequence Odes 1.34-38 to illustrate how such readings may emerge.

The role of the "author" in such author-reader dialogue nevertheless requires clarification. Chapter 3 draws on Bakhtin to make a distinction between the "primary author" - the historical individual who composes the literary work - and the "secondary author", or the controlling consciousness behind its text. While acknowledging the complex interplay between these two personae, especially in the case of Horace, where the voice of the poet is continually present within his verse, I define "Horace" for the purpose of my analysis as the secondary author whose consciousness is immanent within his texts. The chapter then examines how this Horace sets about establishing his poetic credentials and cultivating an audience able to engage in dialogue with him. His goal, as developed in Satires 1, is to create a company of lectores docti, which he models on the amicitia relationship developed with Maecenas and his circle. The dialogic dimension of this projected relationship is implicit in the conversational mode (sermo) adopted for the Satires, and the injection by the poet of a first-person persona that seeks a friendly complicity with those who are invited to be his amici docti.

Chapter 4 then examines Horace's search for an appropriate poetic vehicle for his literary project, which he explores through the composition of the Epodes. In this 
collection, he on the one hand demonstrates a commitment to the prevailing Alexandrian aesthetic for poetry that was 'slender' and artfully composed, but on the other also reveals an ambition to assert an oracular role as a vates within his contemporary society in order to bring attention to its political, social and moral weaknesses. The Epodes show that his first choice of vehicle for this purpose was the iambus, whose artifice he drew from Callimachus while taking its metre, spirit and passion from Archilochus. ${ }^{4}$ But analysis of the Epodes will reveal that, for Horace, the association in the public mind of iambic with invective proved too strong to overcome. The later poems in this collection show that in consequence he eventually turns away from iambic in favour of lyric forms, whose models he adopts principally from the Archaic Greek lyrikoi. Nevertheless, the Epodes stand as a single collection whose metapoetic progression is reinforced by lexical linkages already apparent between individual poems. The prior importance of the whole book over any individual poem contained within it is already an evident aspect of Horace's poetic construction.

Chapter 5 completes the analysis of Horace's poetic project by considering the construction of the lyric opus that is Odes 1-3. The specific challenge for the poet in adopting the lyric mode is to educate his acquired audience in how to read a form of poetry that is effectively new in Roman literature, and hence for which they have little or no prior experience or expectation. The analysis examines how, in Book 1, the poet lays out for his audience the range of metres to be used, tying these in by means of intertextual echoes with their Greek antecedents, then the range of themes and forms that can be encompassed within the lyric genre. At the same time, he carries on a progressive metapoetic discussion with his readers, challenging any presuppositions they might have about the role of "light" poetry, and inducing them gradually to find more subtle commentaries in the verse. Book 2 then adopts a more measured tone and rhythm as the poet embarks upon more socially involved themes and lays greater claim for himself as vates. Finally, in Book 3, Horace claims this vatic role openly, speaking directly to his society through the "Roman Odes" (3.1-6), before bringing his grand opus to a climactic close by retraversing the whole panoply of the lyric genre.

4 Horace assert as much in Epist. 1.19.24, a passage I will discuss more fully in Chapter 4. 
In relation, then, to the patterns of lexical repetition, my overall hypothesis is that these create a sense of continuity for the whole work, eliciting overlapping harmonies of meaning between individual poems that tie them into the whole, and reinforcing the aesthetic unity of that whole. Rather than being simply isolated rhetorical devices, they bring attention to an important architectonic effect which binds into poetic unity what otherwise outwardly could seem to be a disparate collection of unrelated pieces. ${ }^{5}$

5 As late as half a century ago the eminent Horatian scholar L. P. Wilkinson (1968: 15) declared: "any idea that the Odes are anything but a miscellaneous collection is chimerical." 


\section{Chapter 1}

\section{Patterns of Repetition in the Odes}

The phenomenon of lexical repetition in Horace's Odes initially came to my attention when I noticed echoes within the first six poems of Book 1 of words which, while not being obscure or particularly unusual in themselves, nevertheless stood out by being used in different thematic or semantic contexts. By "words" in this context I mean the root-morpheme bearing the semantic charge. Thus, "echoes" may be perceived between words of the same semantic root but with different grammatical terminations, or across their cognate parts of speech. Clearly, such echoes are more sharply focused the fewer degrees of morphological separation there are between the word forms. Other factors that may be involved in this focusing are similar positioning in the two poems and/or in their respective lines of verse or similar phonic or metrical effects. Furthermore, on occasion, close syntactic connection with other words which then themselves repeat in a following poem creates a kind of concatenation effect over a number of consecutive poems. Finally, such associations stand out all the more prominently in retrospect if, as one reads further through the books, such terms do not then further recur, or do so only sparingly or at a considerable distance from the initial repeated usages.

To demonstrate, let us consider the following examples from odes 1-6 of Book 1:

\section{(a) pavidus}

1.1.14: numquam demoveas ut trabe Cypria / Myrtoum pavidus nauta secet mare

1.2.11: et superiecto pavidae natarunt / aequora dammae

Thereafter, the radical pav- = "fear, terror" occurs only at 1.15.23 (impavidi), 1.23.2 (pavidam) and 1.37.23 (expavit).

(b) monstrum

1.2.6: grave ne rediret /saeculum Pyrrhae nova monstra questae

1.3.18: qui siccis oculis monstra natantia / qui vidit ...

Monstrum recurs only once more in Book 1, at 1.37.21 (monstrum). 
(c) nato v.

1.2.11: et superiecto pavidae natarunt / aequore dammae

1.3.18: qui siccis oculis monstra natantia / qui vidit ...

Nato (to swim, float, flow) is used nowhere else in Book 1, and recurs only twice more in the whole Odes 1-3 corpus, in compound forms at 3.7.28 (denatat) and 3.17.7 (innantem).

It is noteworthy that $C$. 1.3.18 thus connects the two previously cited echoes within the same line of verse. Furthermore, the "swimming monsters" of this line recall not only the swimming deer of 1.2.11, but, since these latter were swimming in the unnatural environment of Deucalion's flood, they themselves were "monstra" in the sense of 'portents' about which Pyrrha was complaining in 1.2.6. One might also adduce a contrastive link back to the first examples with pavidus, in that in 1.1.14 the farmer's son could not be persuaded to become a sailor because of his fear of the sea (pavidus nauta), whereas the intrepid sailor in $C .1 .3$ confronts the swimming monsters fearlessly (siccis oculis).

(d) siccus

1.3.18: qui siccis oculis monstra natantia / qui vidit

1.4.2: $\quad$ trahuntque siccas machinae carinas

In C. 1.3 , siccus is used in the metonymic sense mentioned above, while in the following ode it is applied purely literally as a descriptor of the ships that had been beached during winter. The root sicc- is used three more times in Odes 1, but at some distance, and each time in an extended metaphorical sense relating to drinking wine: at 1.18 .3 (siccis), used substantively to refer to teetotallers, then twice in verbal form, at 1.31.11 (exsiccet) and at 1.35.27 (siccatis) both referring to the draining dry of wine-goblets.

(e) miror

1.4.19: nec tenerum Lycidan mirabere

1.5.6-8: et aspera / nigris aequora ventis / emirabitur insolens

Noteworthy here are the common future-tense uses, which mark contrasting emotions: at C. 1.4.19 the anticipation of regret for the pleasure of beholding one's love that will be denied by death, at 1.5.8 the blank bewilderment of the young 
lover passed over by his supposed mistress. These are the only two usages of the root mir- in Odes 1 the compound form emiror may well have been coined by Horace as it is not attested in any other major extant Latin text. ${ }^{6}$

\section{(f) nescius}

1.5.10-12: qui semper vacuam, semper amabilem /sperat, nescius aurae / fallacis

1.6.5-6: neque haec dicere nec gravem /Pelidae stomachum cedere nescii / .... (conamur)

At $C$. 1.5.11, the adjective nescius is applied to the naïve young lover, lacking in experience. By contrast, at 1.6.6 it is applied to Achilles, a man of great experience who has never backed down from a contest. The negative form nescius is used only in these two instances in Book 1, while the positive root sci- (to know, knowledge) is used only twice, in verbal form, at 1.11.1 (scire nefas) and 1.15.24 (Sthenelus sciens / pugnae).

In addition to these coupled repetitions, the opening cluster of odes in Book 1 also reveals several three-fold repetitions of lexical root forms used only sparingly thereafter. Most apparent are:

\section{(g) veto}

1.3.26: gens humana ruit per vetitum nefas

1.4.15: vitae summa brevis spem nos vetat inchoare longam

1.6.10-12 Musa potens vetat / laudes egregii Caesaris et tua /culpa deterere ingeni

These are the only three instances of the lexeme veto occurring in Book 1. It does not appear at all in Odes 2 and in Odes 3 only in three widespread and disparate usages.

(h) vacuus

1.3.34-35 expertus vacuum Daedalus aera / pinnis non homini datis

1.5.10: qui semper vacuam semper amabilem / sperat

1.6.17-19: nos proelia virginum / ... / cantamus vacui sive quid urimur.

At C. 1.3.34 the adjective is used in its literal sense of "empty", while the two following usages bear its figurative sense of "free, available, unattached to any relationship". Yet 1.5.10 carries an ironic flavour, conveying the naïve lover's

$6 \quad$ Nisbet \& Hubbard (1970) 76. 
deluded hopes, while at 1.6.19 the word is applied by the poetic persona to himself, without irony but perhaps overlaid by some self-directed deprecation. Vacuus then occurs only twice more in Odes 1 , at $C$. 1.18.15 (tollens vacuum plus nimio Gloria verticem) and at 1.32.1 (si quid vacui sub umbra / lusimus). The latter example, however, also refers to Horace's poetic persona, and given its prominence in the opening line of this ode, equally may be considered an echo of C. 1.6.19, particularly given the syntactic parallelism of si quid with the earlier sive quid.

A further intriguing triplet of echoes within this set may be perceived between three lexemes related not through a single root-morpheme but by all being numerical adjectives with grammatical terminations in -plex/icis. These are:

(i) triplex 1.3.9-12 illi robur et aes triplex /circa pectus erat qui fragilem truci / commisit pelago ratem / primus

$\begin{array}{lll}\text { simplex } & \text { 1.5.4-5 } & \text { cui flavam religas comam / simplex munditiis } \\ \text { duplex } & 1.6 .7 & \text { nec cursus duplicis per mare Ulixei }\end{array}$

At $C$. 1.3.9, the first seafarer who braved the oceans in a little boat is described as having a chest bound with oak and triple layers of brass - an image of stoutheartedness. At $C$. 1.5.5, on the other hand, the dazzling mistress Pyrrha is portrayed as being simplex munditiis - simple in her elegance. But the reverberation of the two adjectives with the ending -plex: triplex, simplex brings also a literal dimension to that simplicity, suggesting that, though her pectus is not mentioned, it is bound by no more than a single layer, especially given that two lines before the lovers are shown as embracing in a cavern. Then at $C .1 .6 .7$, the adjective duplex, used in its figurative sense of false, deceitful, qualifies Ulysses. But we note also that the adjective is applied to him in a maritime context, which recalls the use of triplex in $C$. 1.3. And as we read $C$. 1.6 we may equally remember that Pyrrha, who appeared so simplex, in fact also would prove duplicitous towards her lover. ${ }^{7}$ Simplex is found only once more in Book 1, at C. 1.38.5, and once only in Book 2 at C. 2.8.14, while not at all in Book 3. Neither duplex nor triplex are used again within the Odes 1-3 corpus.

The repetitions highlighted above stand out particularly because of the infrequency of any later occurrence either within Book 1 or the whole corpus. It must also be recognized, however, that other lexemes repeat with greater frequency, to the extent that particular pairs or sequences of these may not command the same immediate

Nisbet and Hubbard, (1970) 75, note: "Simplex shows the simplicity of Pyrrha's 'toilette'; [...]. At the same time it suggests the opposite of duplex animi. One foolishly expects that Pyrrha's innocent appearance will be matched by her behaviour." At their note on duplicis at 1.6 .7 (85), the two commentators interpret the usage as "double-dealing', the opposite of simplex". 
notice. Nevertheless, when lexemes repeating multiple times are clustered over a limited range of odes, and are then used infrequently or with a widely separated distribution thereafter, the sudden absence of these previously frequent forms becomes perceptible the further the book is read. In retrospect, therefore, the earlier sequences may then come again to mind as creating an underlying motif permeating the range of poems over which they are used. In Book 1, this pattern is observable in the recurrences of celer (odes 12, 14, 15, 16, then nowhere else); ignis (odes 10,12, 13, 15, 16, 17, but otherwise only at ode 3, then at 27, 34 and 37); mare (11 recurrences over the first 16 odes, then only three times over two odes thereafter); terra (seven times over the first four odes, then only four other widely separated usages), among others. All such occurrences have been included in the electronic appendices.

Investigation of Book 2 shows up similar and arguably even more marked patterns of repetition. Progressive reading through the first half of the book reveals paired usages in consecutive odes, concatenations of linked lexemes over several poems, and clusters of recurrences over a limited range. The second half of the book shows a cluster of recurrences involving the lexeme centum, either as a stand-alone numeral (centum) at C. 2.14.26 and 2.16.33, or as part of a compound noun or adjective: centiceps at 2.13.34, trecenis at 2.14.5 and centimanus at 2.17.14. Centiceps and centimanus in their turn form part of a parallel sequence of similar inter-related compounds involving body parts or animals: decempedis at 2.15.14, Capricornus at 2.17.20 and capripedum and trilingui at 2.19.4 and 2.19.29 respectively. Most notably in Book 2 are found 14 recurrences of nine different adjectives in -ax/-acis, spread evenly over 11 different odes from C. 2.1 to 2.19. Outside of Book 2, however, such forms recur just 11 other times over the remaining 68 odes of the corpus, at widely spaced intervals. Five of these adjectives occur only once more, and two not at all again.

Some of the more prominent sequential recurrences in Book 2 include:

(j) tempero

2.2.2-4 inimice lamnae / Crispe Sallusti nisi temperato / splendeat usu

2.3.3 [mentem] ... / ab insolenti temperatam / laetitia 
What draws particular attention to this recurrence is the common participial form of the verb, and the occurrence of both of these in final position in the respective third lines of each poem, although the metres are different (Sapphic followed by Alcaic). ${ }^{8}$ Tempero occurs only once more in Book 2, at C. 2.16.27 (temperet).

\section{(k) insolens}

\subsection{3 [mentem] ... ab insolenti temperatam / laetitia}

2.4.2 prius insolentem /serva Briseis niveo colore / movit Achillem

This is an example of the concatenation effect already noticed in Book 1, where a prior linkage then projects forward via another term in the same line. Here again the same form of the lexeme insolens (participial adjective) recurs at nearly the same point in each ode. The adjective nevertheless undergoes both a semantic and functional shift, from modifying an abstract noun (laetitia) and carrying the sense of "unwonted, (socially or morally) excessive", to a 'redundant' epithet applied to Achilles, with the sense of "arrogant". Yet the proximity of the two usages elicits a further semantic overlay to be projected from the first to the second, which then allows the sense that Achilles' reaction to the cession of Briseis was in itself excessive in the circumstances. These are the only two usages of the root-morpheme sole- ("to be usual") in this book.

\section{(I) obligo}

\subsubsection{7 ergo obligatam redde lovi dapem}

2.8.5-6 simul obligasti / perfidum votis caput

Here, both verb forms are of four syllables with identical stress accent on the penultimate syllable. The second usage, however, by being placed next to perfidum subtly undermines the standard sense of "ritually pledged" carried by the first. These are the only places in the whole corpus where the verb obligo occurs, and its cognates are limited to four occurrences, religo at $C$. 1.5.4, 1.32.7 and C. 2.11.24, all with the literal sense of "tying up", and the participial illigatum at C. 1.27.23.

There occurs as well in Book 2 the repetition of two-word phrases in adjacent poems on several occasions. Two examples are:

8 West (1998) 27 notes this repetition as one of "many details in common" between the two poems but does not otherwise analyse its significance. Nisbet \& Hubbard (1978) 39, 56, fail to make any linkage. 


\section{(m) iugum ferre}

2.5.1 nondum subacta ferre iugum valet / cervice

2.6.2 Cantabrum indoctum ferre iuga nostra

The prominence of this repetition is reinforced by the positioning of the phrases at the beginning of their respective poems and in the same relative position within their lines of verse as well as by the use of the infinitive form of the verb ferre in each case. The contrast comes from the literal use of the expression ferre iugum in C. 2.5.1., where it is related to a young heifer not yet strong enough to be yoked to a plough, whereas at $C$. 2.6.2 the reference is figurative, applied in the sense of political subjugation of a people. The significance, though, is that in each case, neither the heifer nor the Cantabri have yet been taught to bear the yoke.

\section{(n) semper urgere}

2.9.9-10 tu semper urges flebilibus modis / Mysten ademptum

2.10.2-3 rectius vives, Licini, neque altum / semper urgendo

In this pair the verb phrase occurs at or within one syllable of the beginning of the respective lines with the adverb semper in each case in the emphatic initial position. The sense of urgeo in both situations is figurative, but is applied to a human object in C. 2.9.10, where Horace is chiding his friend Valgius for continuing to pursue his lost lover Mystes with wretched verses, while at C. 2.10.3, the usage incorporates a maritime metaphor, where the addressee is advised to steer a middle path in life between thrusting out to the open sea (altum urgere) or sailing too close to land. Urgeo, while used five times in Book 1, occurs only once more in Book 2, at C. 2.18.20, and not at all in Book 3.

A similar echo of the paired lexemes unda and aestuo occurs at C. 2.6.4 and 2.7.16. Here the syntactic structures linking the pairs are dissimilar, but the imagery evoked is the same: ubi .... / aestuat unda (2.6.4) and te ... / unda tulit fretis aestuosis (2.7.16).

Likewise, the pairing of truncus and labi at C. 2.17.27-28: me truncus illapsus cerebro / sustulerat is echoed at C. 2.19.11-12: truncis / lapsa cavis iterare mella. In both cases the two common lexemes stand next to each other (though across the inter-verse enjambment in the second case), but are distinct in terms of their syntactic associations: illapsus is a participial complement of truncus in the first example, whereas in the second, lapsa modifies mella with truncis as its adverbial complement. While forms of labi occur four times each in Books 1 and 3, and also at C. 2.14.2, truncus is found nowhere else in the Odes 1-3 corpus. 
Several clusters of lexemes repeated multiple times over a limited range of poems also occur in Book 2. A notable example is the lexeme color, which occurs four times within the first five odes of this book (C. 2.1.35: decoloravere; 2.2.1: color; 2.4.2: colore; 2.5.13: colore) while appearing only once in Book 1 (C. 1.13.5) and once in Book 3 (C. 3.5.27). Interestingly, C. 2.5.13 identifies the colour in question in that text as purple (racemos / purpureo ... colore). The lexeme purpura then recurs another three times throughout the rest of the book (C. 2.12.3: purpureum; 2.16.7: purpura; 2.18.8: purpuras). Outside of Book 2 the lexeme purpura occurs once in Book 1 (C. 1.35.12) and three times in Book 3 (C. 3.1.42; 3.3.12; 3.15.15).

In Book 3, lexical repetition tends to occur in clusters of three to five or more usages over a limited range of poems, rather than in the single isolated pairs or concatenations characteristic of the first two books. This suggests that a common thematic function linking contiguous poems may be more at play in Book 3, rather than the contrastive usages that tend to predominate in Odes 1 and 2 . For example, the theme of "instruction" emerges across the range $C$. 3.6 to 3.10 where various forms of the rootmorphere doc- (to teach) recur six times: twice in C. 3.6 at 3.6.21 (doceri) and 3.6.38 (docta); at C. 3.7.19 (docentis); at C. 3.8.5 (docte); at C. 3.9.10 (docta) and at C. 3.10.1 (docilis). This pattern is then discontinued, with the only other examples of the lexeme in Book 3 occurring earlier at C. 3.3.14 (indocili) and later at C. 3.24.56 (doctior).

In similar fashion, the theme of "seeking" recurs perceptibly over the range $C$. 3.14 to 3.20 with the lexeme peto repeating 8 times within that span: three times in $C .3 .14$, at 3.14.2 (petiisse laurum), 3.14.3 (repetit penatis) and 3.14.17 (pete unguentum); twice in C. 3.16, at 3.16.22-23 (nil cupientium / nudus castra peto) and 3.16.42-43 (multa petentibus / multa desunt); twice in C. 3.19, at 3.19.14-15 (ternos ter cyathos ... petet / vates) and at 3.19.26-27 (te .... / tempestiva petit Rhode); then once at C. 3.20.6 (ibit insignem repetens Nearchum). Outside of this range, the root-morpheme pet- occurs only two further times within Book 3, at C. 3.1.11 (petitor) and C. 3.27.9 (repetat). 
Particular images also repeat over a short range of poems without being particularly present elsewhere in the book. Three which are notably apparent are:

(o) ianua

3.9.19-20 si flava excutitur Chloe / reiectaeque patet ianua Lydiae

3.10.5 audis quo strepitu ianua [...] remugiat

3.11.15-17 cessit immanis tibi blandienti / ianitor aulae / Cerberus

3.14.23-24 si per invisum mora ianitorem / fiet, abito

The door-image in three of these poems $(3.9,3.10$ and 3.14) relates to that which admits, or conversely shuts out, the lover or his mistress, even though only C. 3.10 can technically be classified as a paraclausithyron, or lament poem of the shut-out lover. ${ }^{9}$ And although the door implicitly present in C. 3.11.16 is that to Hades, guarded by Cerberus, in recalling to Mercury that god's power to charm the grim door-keeper, the poetic persona in this poem is entreating the god similarly to grant him access to his mistress Lyde. The grim door-keeper image is then picked up again in C. 3.14.23, but with a humorously ironical overlay. For here it is the poet's slave who is sent to summon his mistress Neaera out of her door to come to his. But should the doorman block the way out rather than in, then the slave is not to persist. Clearly, in both these latter usages, there are covert allusions to the Orpheus-Eurydice myth, with Horace turning the pathos of that myth to bathos in the Neaera ode. The root-morpheme ian- (door) occurs nowhere else in Book 3 and only at C. 1.25.4 in the remainder of the three-book corpus.

(p) aqua

3.16.29 purae rivus aquae silvaque iugerum

3.17.13-14 aquae nisi fallit augur / annosa cornix

3.19.6 quis aquam temperet ignibus

3.20.15-16 qualis aut Nireus fuit aut aquosa / raptus ab Ida.

The four usages here do not appear otherwise related than through a progression in semantic function. The first, at $C$. 3.16 .29 is purely literal, while at $C$. 3.17.3, aquae is a metonym for rain. At $C$. 3.19.6, though the sense is once again literal ("who will heat water with fire"), the normal expectation of combining the verb tempero with ignis and aqua would be the opposite: quis aquā temperet ignis. At C. 3.20.15, aquosa is a purely decorative epithet for Ida. Elsewhere, the root aqu(water) is used in three other widespread instances in Book 3, at C. 3.1.30 (aquas), C. 3.4.8 (aquae) and C. 3.30.11 (aquae), and twice in Book 1, at C. 1.1.22 (aquae) and C. 1.31.8 (aqua). It does not occur at all in Book 2 .

9 Günther (2013) 351. 
(q) nix

3.23.9-10 nam quae nivali pascitur Algido / devota quercus inter et ilices

3.24.38-40 nec Boreae finitimum latus /durataeque solo nives / mercatorem abigunt

3.25.10-11 Hebrum prospiciens et nive candidum / Thracen

3.26.9-10 o quae beatam diva tenes Cyprum et /Memphin carentem Sithonia nive

3.27.25-26 sic et Europe niveum doloso / credidit tauro latus

Outside of this sequence of repetitions over five consecutive poems, an occurrence that is extremely rare across the Odes 1-3 collection, the lexeme nix/nivis (snow) occurs only one other time in Book 3, at C. 3.10 .7 (nives). It is found in three distinct places in Book 1, at C. 1.2.1 (nivis), at C. 1.9.1 (nive) and at C. 1.37.19 (nivalis), but once only in Book 2, at C. 2.4.3, where it is used in a figurative sense (niveo colore). An intertextual allusion may however be perceived between C. 3.25.10-11 above (prospiciens ... nive candidum / Thracen) and C. 1.9.12 (vides ut alta stet nive candidum / Soracte), where the association is reinforced both by the common phrase standing in identical position at the respective line endings and preceding a geographical name in enjambement, as by the common imagery of a snowy landscape viewed from afar.

This final cluster of poems from C. 3.24 to $C .3 .30$ also shows significant repetitions of adjectival or participial forms in -ens, most notably carens: at C. 3.24 .17 (matre carentibus), C. 3.26.10 (Memphin carentem ... nive) and C. 3.27 .39 (vitiis carentem), and potens: at C. 3.25.14 (o Naiadum potens), C. 3.27.33-34 (centum ... potentem / oppidis Creten), C. 3.29.41 (ille potens sui) and twice in the final poem of the entire collection, C. 3.30, at 3.30.3-4 (quod ....non Aquilo impotens / diruere possit) and 3.30 .12 ([ego] ex humili potens). ${ }^{10}$ The morpheme care- (to be lacking) also occurs in the form caret at $C$. 3.29.23, but outside of this sequence only again at $C$. 3.19.8 (caream), while the lexeme potens (powerful) appears elsewhere in Book 3 only at C. 3.16.10 (potentius).

Such patterns of lexical repetition across the three books of the Odes consequently invite the consideration of the extent of authorial intention in their arrangement. Verbal reminiscences between particular poems of the collection have certainly been noted and commented on before, in particular in two near-contemporaneous studies in the

10 Other examples are fugiens (twice), recens (thrice) and a number of single usages. 
1980s by Matthew Santirocco ${ }^{11}$ and David Porter. ${ }^{12}$ Both authors contend ${ }^{13}$ that lexical reminiscence, together with metrical and thematic linkages or contrasts, the linear progression of the ancient papyrus book that effectively required sequential reading, and tonal variation, was a factor in the ordering of the collection. But how far lexical repetitions helped determine the specific placement of individual odes by the author is difficult to establish. Porter in particular places a large emphasis on verbal echoes in constructing an elaborate architecture for the Odes which in his view provides a coherent design for the overall work and which he by implication attributes to Horace himself. Santirocco is more circumspect, attributing a somewhat more limited role to verbal echoes in his projection of the unity and general design of the Odes, as well as canvassing various possible architectures for particular poem sequences. However, in the years since these studies appeared, neither author's schemata have gained much critical acceptance.

In the light of this scepticism, any further visitation of the phenomenon of lexical reminiscence in the Odes needs to address several related issues. Firstly, if we may reasonably assume, along with Santirocco, ${ }^{14}$ that, in the absence of evidence to the contrary, the Odes 1-3 collection as we have it was ordered by Horace himself, then are the lexical repetitions that are demonstrably present, particularly those in consecutive poems or closely contiguous clusters, the result of intentional collocation on the part of the author, or are they merely fortuitous recurrences whose placement does not vary significantly from what might be found in any random distribution of the odes in each book? Secondly, and depending on what conclusions might be reached to this first question, what functional or aesthetic purpose might the author have intended for such repetitions, or conversely, what interpretive response might reasonably be drawn from such patterns by readers, whether ancient or modern?

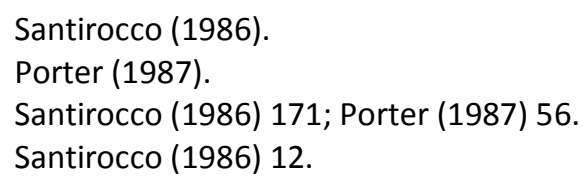


My first recourse in addressing this problem was to submit Book 1 of the Odes to rigorous statistical analysis. ${ }^{15}$ The lexical sample analysed was established first by deleting all purely functional or non-semantically marked vocabulary, such as conjunctions, prepositions, pronouns, relatives and negative particles, from the total Book 1 corpus of 3958 words, leaving 3223 semantically significant terms. This set in turn reduced to 1272 significant head words (SHWs), as defined at the beginning of this chapter, of which 653 recur more than once over the 38 poems. ${ }^{16}$ It was the distribution of these recurrent head words that was then subjected to the statistical analysis.

The approach adopted and the results reached are as follows:

A statistical approach was used to evaluate the evidence that the author employed the device of "echoing" significant head words (SHWs) in successive odes for poetic effect. One way an echoing strategy might manifest itself would be for there to be an unexpectedly high proportion of SHWs appearing in runs of $2,3,4 \ldots$ successive odes. Because a word which occurs in many odes is inherently more likely to appear in successive odes, any evaluation of the evidence of an excess of runs needs to factor in the ode frequency of each word.

We have therefore calculated the incidence of 2-runs and 3-runs observed for words of all possible frequencies (labelled "actual" in plots) and compared it with the average that would be expected if each of the words had been allocated to their observed number of odes at random (points labelled "theory"). The theoretical numbers were estimated by random simulation. As can be seen from the plots below, the number of SHWs with 2-runs and 3-runs is no greater than would be expected from random allocation of each SHW words to the odes.

There were only four SHWs that appeared in four successive odes and no runs longer than four.

The test against randomness outlined above is only approximate, because the theoretical model used to simulate a random pattern ignores the varying lengths of the odes. To run a more robust test, we also carried out simulations in which we randomly varied the orders of the actual odes and then calculated the numbers of SHWs with 2-runs observed. Note that 653/1272 (i.e. $51.34 \%$ ) of the SHWs appear in at least 2 odes, and are therefore eligible for a 2-run. For the odes in Horace's order, 147/653 (22.5\%) had at least one 2-run. Of course the number of possible orders for 38 odes is unimaginably large $\left(5.23 \times 10^{44}\right)$. So there is no question of testing every order. Instead we have generated 500 ode orders at random and for each order calculated the total number of SHWs which have at

15 For this work I am indebted to my long-time statistician friend Dr Ray Littler, now Honorary Fellow in the Department of Statistics at the University of Waikato, whose conclusions I have reproduced here.

16 Full lists of these various lexical sets can be found in the electronic spread-sheet appendices. 
least one 2-run. The histogram below (Figure 1) shows that the order chosen actually has a number of 2-runs which is not all unusual had Horace simply thrown the odes down at random. In fact about $80 \%$ of random ordering of the odes would produce more 2-runs than were actually observed.

Figure 1:

Histogram of total 2-runs observed with $\mathbf{5 0 0}$ random orders with fitted Gaussian distribution

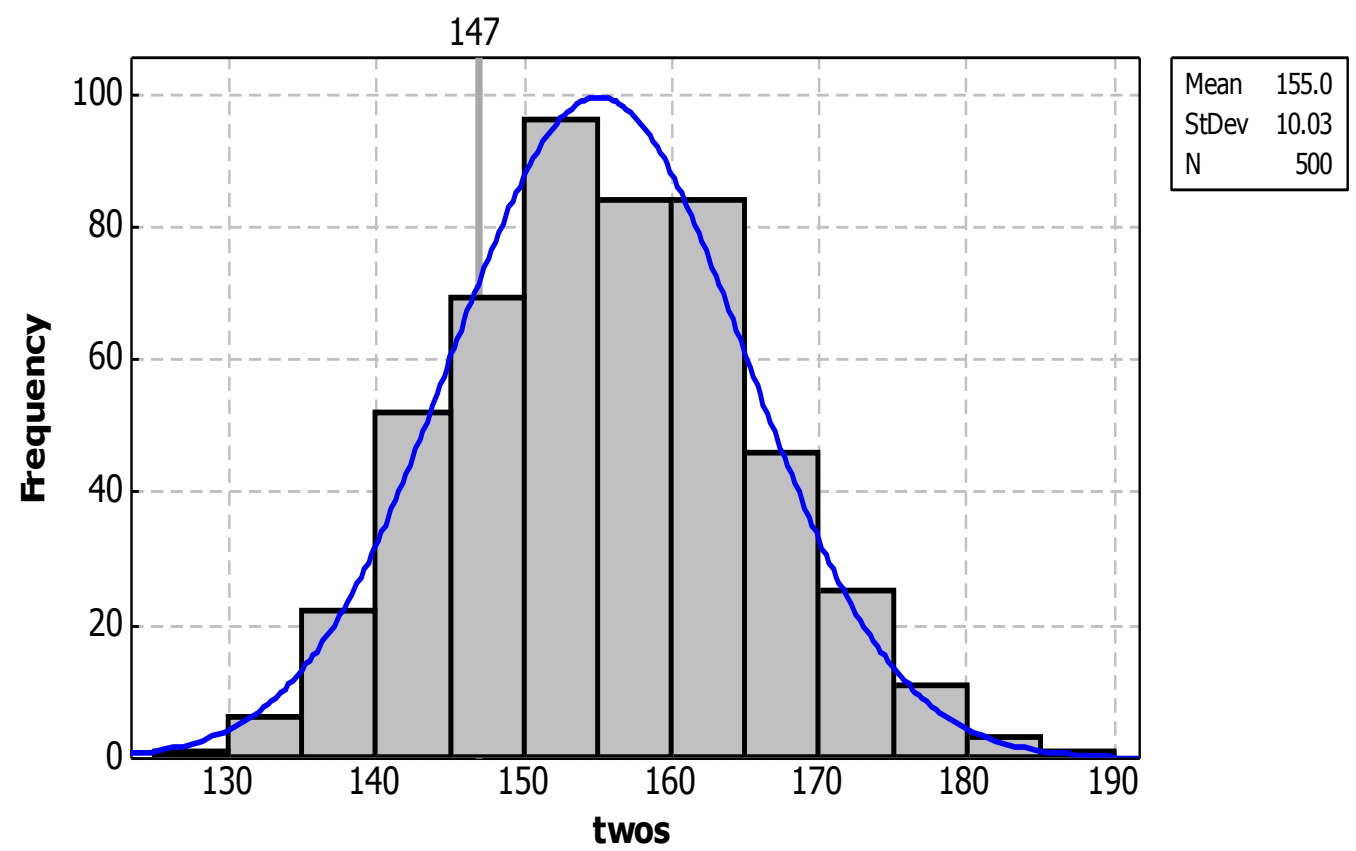

Project: HORACE1.MPJ; Worksheet: for simtest; 21/11/2013 2:50:40 p.m.; RayLittler WASU 
Figure 2:

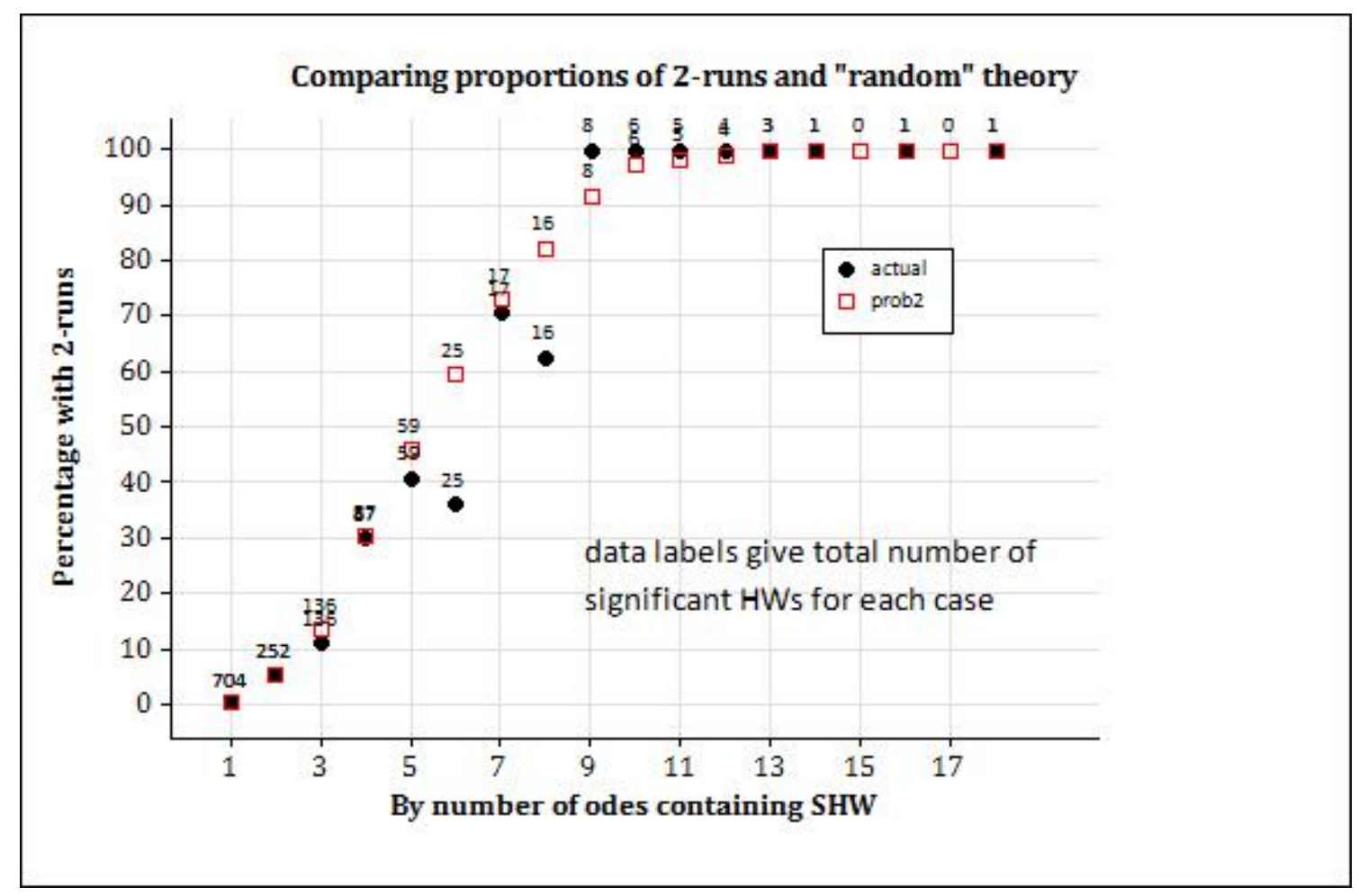

Figure 3:

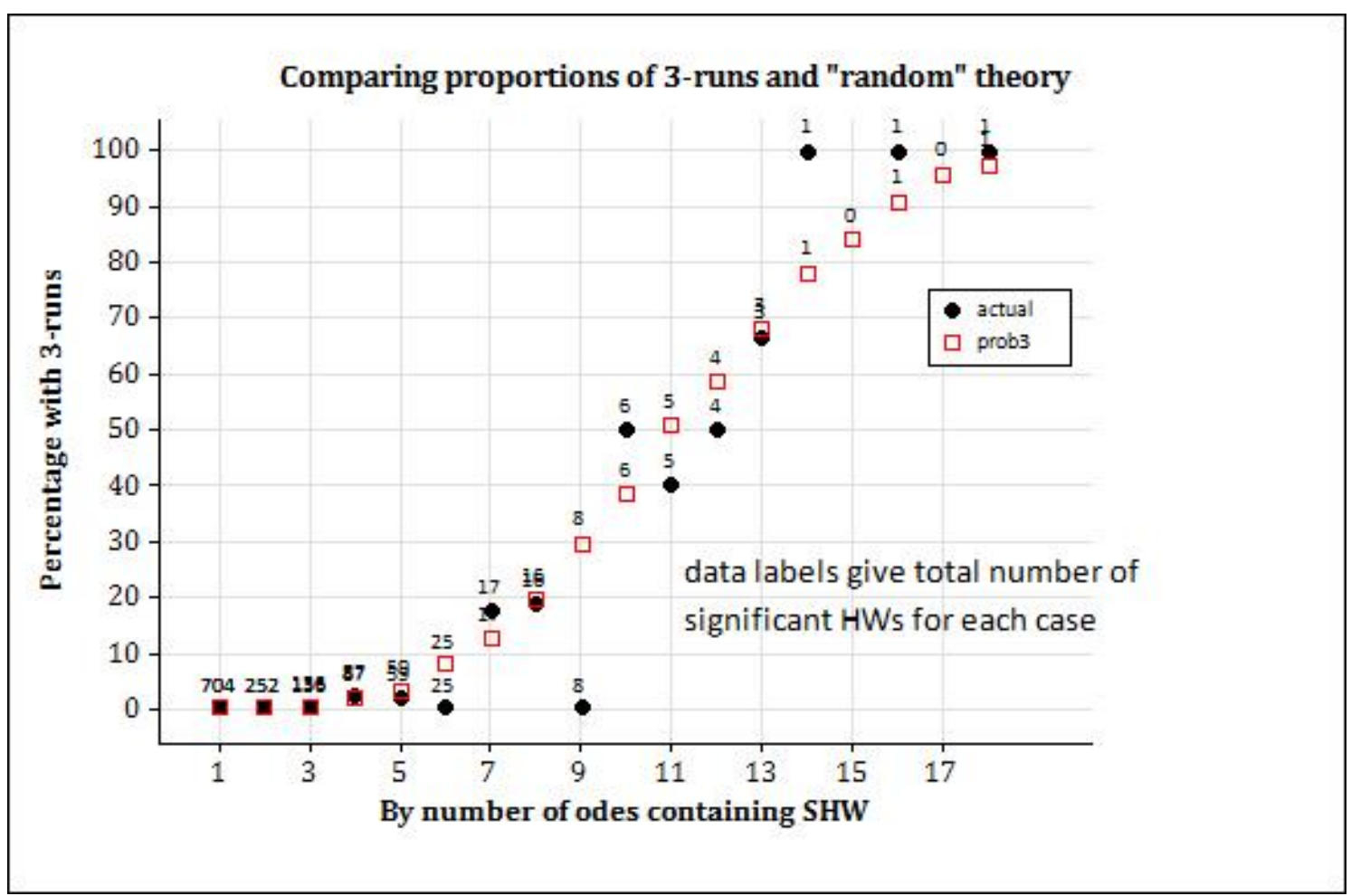


Similar analysis was not subsequently carried out on Books 2 and 3 of the Odes, but there is no prima facie evidence from these books to suggest that the results would be significantly different from those for Book 1. Our analysis makes it clear that no definitive conclusions can be derived over the intentional placement of particular odes in specific orders to create sequential patterns of lexical repetition. Likewise it can be extrapolated from the same analysis that any other specific placements of odes that employ the mechanism of lexical repetition to create architectural schemata of the type postulated particularly by Porter are equally unable to be corroborated by this method.

However, this analysis equally does not prove that authorial intent was not a factor in determining the observed patterns of recurrence. Indeed, more tightly defined parameters for the statistical analysis, such as limiting the samples to particular grammatical forms, or particular positioning of recurring lexemes within poems or lines of verse, might well show patterns that differ significantly from those of random distributions of the odes. However, such criteria open themselves up to the criticism of being selective, and hence chosen simply to confirm an a priori impression, as well as to being too small in number within a corpus limited to fewer than 1000 words to be statistically significant. All that can be definitively concluded, therefore, is that the statistical method does not provide an absolute tool for determining how intentional the specific repetitions observable within the published collection of Odes 1-3 were for Horace at the time that he compiled it and gave it its final order. It is indeed still conceivable within this methodology that the author did intentionally order his opus in such a way that certain specific lexical repetitions should occur between consecutive or closely proximate poems, even though such interventions in themselves did not create more patterns of repetition than would be produced by any random order.

In the light of these observations, however, further investigation of the phenomenon of lexical repetition must necessarily embrace the fact that such recurrences only manifest themselves when they are perceived by the reader. They are effectively realized by the reader, whether or not the author intended that she or he should connect them. But does this then rule the author entirely out of the equation? This vexed question falls within the domain of reader-reception theory to which I wish to devote the next chapter. 


\section{Chapter 2}

\section{Author-Intention and Reader-Reception}

In considering the extent to which patterns of lexical repetition in the Odes are the result of authorial intention in their placement or of reader perception in their realization, let us begin by summarizing what may reasonably be taken as established a priori:

1) The poems comprising Odes 1-3 were all composed in the form we now have them by the poet Horace himself. There is no evidence that individual poems of uncertain attribution were ever added to the collection or that any of the odes were emended by ancient editors after Horace's death.

2) It is effectively accepted ${ }^{17}$ that the distribution of the odes within the three books, and their order within each book, was established by the poet himself.

3) A considerable number of lexical repetitions or echoes of the kinds illustrated in Chapter 1 are demonstrably present between consecutive or closely proximate poems across all three books.

Of these three aspects, the first two may safely be taken as representing the intent of the author at the moment of publication of Odes 1-3. The third, however, is more problematic, as it depends on what may be defined as a lexical repetition, echo or reminiscence, and how far this repetition is perceived as such by the reader. Clearly, the inflected nature of Latin lexis when employed in communicative utterance means, as earlier demonstrated, that it is only rarely that repeating pairs or clusters of lexemes recur in exactly the same orthographic form. Hence the recognition by a reader of a repetition depends on that reader's perception of a common semantic or formal component between the paired elements. While this may be taken as reasonably obvious for the various declined forms of Latin nouns and adjectives, and perhaps to a

17 As earlier affirmed by Collinge (1961) 36 and Santirocco (1986) 12. 
slightly lesser extent for conjugated verb forms ${ }^{18}$, perception of a verbal echo may become less acute or even not take place for compound or cognate forms of a particular lexeme. Hence, however much the Latin author may have intended a lexical echo to be perceived, its perception depends on the extent to which the reader conceives of such linguistic phenomena and his/her perspicacity in noticing them. In the case of collections of poems like the Odes, such notice also depends on whether the poems containing the repeating lexemes are read in association with each other, or whether they are read separately on different occasions. Small wonder then that not much attention, outside of writers like Santirocco and Porter, seems to have been paid to lexical repetition in Horace, ${ }^{19}$ with most commentaries explicating the odes individually as self-contained compositions.

Thus far, however, we have considered intention and reception only in relation to the formal dimension of lexical repetition. Of more significant interest is the extent to which such repetitions influence the meanings to be attributed both to the individual components of each linked pair or cluster, and beyond them, to the interpretation of the poems in which they are included. We have already in Chapter 1 canvassed some potential effects of these linkages. Are these however simply the consequence of reader-response or do they point to a meaning intended by the poet himself? This in turn leads us to consideration of the general issue of how meaning is realized in literary texts, and the relative contributions of both author and reader to the generation of such meaning. This question in particular has been at the forefront of reader-reception

18 This lesser degree of perceptibility may particularly apply in cases where the verb stem changes for certain tenses or forms, e.g for verbs like fero, tollo, or where a perfective tense shows a redoubled prefix, as with parco-peperci, disco-didici etc.

19 In addition to Santirocco (1986) and Porter (1987) one other exception is the review article by Robert Renehan in CP 83.4 (1988) 311-328 of Shackleton Bailey's edition of Horace. Renehan draws attention to the "repetition [...] by which the same word is used in two successive poems", observing that "this phenomenon is so frequent in Horace that chance seems to be excluded." (317). He then goes on to list a large number of such repetitions from the Odes, as well as drawing attention (320) to the "remarkable clusters of apparent echoes" occurring in "poems separated by one intervening poem." Renehan concludes from this evidence that "Horace consciously employs such repetition as a deliberate linking device" (317), but does not discuss any further schematic or poetic function they may have. The relative lack of critical attention to lexical repetition in ancient poets in general is subsequently commented on by Jeffrey Wills (1996) 475: "The fact is that proximate repetitions are not uncommon in ancient poets [...]. At present, the phenomenon does not lack evidence for its existence - what it needs is explanation." 
theory, notably as developed by the German literary theorists Hans Robert Jauss and Wolfgang Iser since the 1970s, based on earlier work on hermeneutics by Roman Ingarden in the 1930s and Hans-Georg Gadamer in the 1960s.

The base premise of recent reception theory in its "fundamentalist" form ${ }^{20}$ is that summed up by Charles Martindale in 1993:

Meaning, we could say, is always realized at the point of reception; if so, we cannot assume that an 'intention' is effectively communicated within any text. And also, it appears, a writer can never control the reception of his or her work [...]. ${ }^{21}$

However, in relation to Horace, the question of intention needs to be considered on two levels: that concerning the textual repetitions on the one hand, and the meaning or interpretation to be drawn from these on the other. In relation to poetry, Stephen Hinds find the "occlusion" of the author much harder to justify "in matters involving close textual explication of particular phrases, lines or paragraphs." 22

However, Hinds makes these comments within the context of his discussion of intertextual allusion, that is, echoes between texts of different authors which may sometimes be limited to a single, prominent word ${ }^{23}$, but more frequently relate to multiple-word phrases or (near-) equivalent lines, and hence where author intent may be more reasonably presumed, if only on the greater statistical unlikelihood of such multiple phrases recurring purely by chance. With Horace, on the other hand, we are dealing with intra-textual echoes within his own opus. While we might reasonably postulate, along with Renehan, that the frequency of the repetitions seems to exclude chance, our statistical analysis does not support this hypothesis. Hence, on the textual level, we can only securely address these on the basis of reader-perception. By extension, therefore, the interpretation of them must fall within the domain of readerreception.

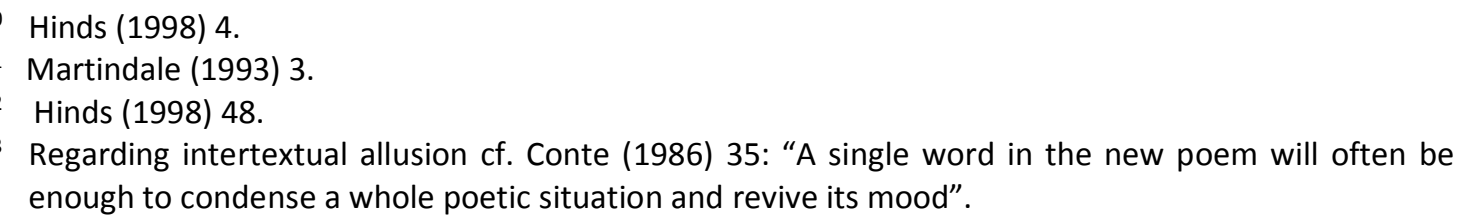
enough to condense a whole poetic situation and revive its mood". 
But this then raises another set of issues for reception theory. Who is meant by "the reader", and how does that reader "read", that is, derive meaning from the text? Does that reader have complete autonomy to derive meaning, and hence is one derived meaning as valid as any other? Does the text itself "imply" a certain reader or "point to" a particular way it is to be read? Further, in relation to any non-contemporaneous text, a fortiori then to an ancient one, as I read, how far am I attempting to discover the meaning its original audience ${ }^{24}$ may have drawn from it, as opposed to the meaning I derive at the point of reading within my own socio-cultural and linguistic framework?

These are some of the questions that the reception theorists have grappled with, without to date reaching many definitive conclusions. Let us begin then with Martindale's assertion that "meaning is always realized at the point of reception". ${ }^{25}$ This declaration immediately raises three questions:

(i) in relation to a literary text, what kind of meaning are we talking about?

(ii) what is involved in the process ${ }^{26}$ of its realization? and

(iii) where and when is the point of reception?

Within any text, meaning relates to the interpretive response on a variety of levels to the linguistic and communicative phenomena present. For a literary work, we might identify at least four levels:

1) the comprehension of the semantic value of the individual words of the text (signs);

2) the reception of the act of communication (message) imparted by the syntax;

3) the apprehension of a potential but indeterminate ${ }^{27}$ reality mediated by the text;

24 Edmunds (2001) 39 argues that even the notion of the "original audience" itself is a problematic concept, as a poem's received meaning might change within a very short time of its first reception. Compare Martindale (1993) 7: "We cannot get back to any originary meaning wholly free of subsequent accretions."

25 Other authors, e.g. Batstone (2006) 14, term the process the "constitution" or "actualization" of meaning, while Iser (1978) 2, following Ingarden, prefers "concretization."

26 Goldhill (2010) 67 locates the construction of meaning "in the process of reception" rather than at the "point" of reception, from which Perris (2011) 209 derives the conclusion that "we should treat reception as an ongoing aesthetic encounter, always in process, forever contingent."

27 Ingarden is quoted by Holub (1984) 24 to say: "We find a place of indeterminacy (Unbestimmtheitsstelle) wherever it is impossible, on the basis of sentences in the work, to say 
4) the synthesis of a reflection about the nature of the real, extra-textual world stimulated by the reading of the text.

For each of these levels of "meaning" we may discern a different process governing its realization. To distinguish between these, the terms used by the different commentators might usefully be appropriated to more specific uses:

1) the meaning of the individual word (sign) is realized (distilled out of potentiality) by the reader's associating the sign (the mark on the page) with a concept lodged in his/her mind;

2) the meaning of the syntactic phrase is actualized (brought into present awareness) by the reader's decoding the syntax to enable perception of a coherent message;

3) the potential reality evoked by the text is concretized by the reader by mentally comparing it with his/her real world experience;

4) a commentary about the real, extra-textual world, whether universal or related to a particular time, may consequently be constructed in the mind of the reader as the result of stimulus by the text.

For the text to function at all as a communication, however, at least the first two of these processes need to be realized and actualized, although perhaps with varying degrees of clarity, particularly in the case of works in a language like Latin that no longer has actuality. For the text to be perceived as a work of art, concretization at the third level must surely happen as well. The construction of the fourth level, however, is completely arbitrary and entirely contingent on whether the text arouses any such response in the reader or not.

The extent of reader autonomy in the realization of meaning over these four levels also varies considerably. The semantic and syntactic norms governing the language of

whether a certain object or objective situation has a certain attribute." Iser (1978) 169 reflects Ingarden's idea of indeterminacy in his notion of "gaps in the text, - blanks which the reader is to fill in". 
expression limit the range of meanings accessible at the first two levels, although some variation in reading is possible, particularly on the syntactic level. On the two subsequent levels, however, as Iser observes, in critiquing Ingarden's concept of indeterminacy, "the filling of the gaps [...] must in principle allow a whole spectrum of concretizations." 28 But Iser notes also that despite this, Ingarden still wishes to distinguish between "true" and "false" concretizations of the work, whereas the former doubts "whether each reader's individual concretization can be subjected to criteria of adequacy or inadequacy." 29

This observation crystallizes one of the fundamental issues of reader-reception theory: whether any "correct" meaning can be attributed to a text, or whether all responses to it are equally valid. The two diametrically opposite positions on this issue are characterized by Duncan Kennedy 30 "as reflecting "classic realism" on the one hand, and "anti-realism" on the other. From the "realist" point of view, Kennedy observes, "texts are thought to have 'real' meaning, existing in concealment, but 'discovered' in the act of reception to have been there all along". For the anti-realist position, he quotes Martindale's affirmation that "there is no Archimedean point from which we can arrive at a final, correct meaning for any text." ${ }^{31}$

The German theorists have also projected ambivalent views on this question. Iser, though conceding readers' apparent freedom to concretize in different fashions or to create different meanings, nevertheless takes back some of these freedoms by talking about readers "grasping the underlying connections between the blanks" and referring to texts' "determinate meaning" and "the message of the work". ${ }^{32}$ Likewise, Gadamer's hermeneutics are "intimately linked with the concern to discover the correct sense of texts". ${ }^{33}$

Iser (1978) 171.

29 Iser (1978) 171.

30 Kennedy (2006) 290.

31 Martindale (2006) 3.

32 Holub (1984) 102, quoting from Iser, The Act of Reading (1978) 198, 81, 98.

33 Holub (1984) 39. 
Yet such criticisms appear overstated. The key question appears to be to what extent a text may contain guides or markers which provide a framework within which readers are invited to induce meaning from a text, without that meaning necessarily being predetermined. This issue is analysed at some length by Iser in chapter 5 of The Act of Reading, entitled "Grasping a Text: Interplay between Text and Reader". He asserts:

Any successful transfer [of text to reader] depends on the extent to which this text can activate the individual reader's perceiving and processing. Although the text may well incorporate the social norms and values of its possible readers, its function is not merely to present such data, but in fact to use them in order to secure its uptake. In other words, it offers guidance as to what is to be produced, and therefore cannot itself be the product. [...] Reading is not a direct 'internalization', because it is not a one-way process [but] a dynamic interaction between text and reader. We may take as a starting-point the fact that the linguistic signs and structures of the text exhaust their function in triggering developing acts of comprehension. [Iser's emphases] ${ }^{34}$

Adopting Husserl's concept of "protension" (meaning an expectation by the consciousness of what is to come at any point in time), in contrast to "retention" by the memory of what is past, Iser situates the reader's position in the text "at the point of intersection of retention and protension". ${ }^{35}$ Every moment of reading, he declares, is a "dialectic of protension and retention", in which that which is remembered "becomes open to new connections" in a future horizon yet to be occupied, but which itself then becomes modified as the reading proceeds. But, Iser notes, "as there is no definite frame of reference to regulate this process, successful communication must depend on the reader's creative ability." 36

However, if the "protentive" expectations that the text sets up are always fulfilled, the retentive element rapidly fades from view. In that circumstance, any architectural awareness of the text is also muted. But if the "new moment" encountered stands out in some way, causing a "hiatus" or disturbance in the reading flow, it will form a contrast with old moments. Thereby, says Iser "the past will remain as a background to the present, exerting influence on it, and at the same time being modified by the

\footnotetext{
34 Iser (1978) 107-108.

35 Iser (1978) 111.

36 Iser (1978) 112.
} 
present." ${ }^{\prime 37}$ Thus, reading is a two-way process, and this, in Iser's view, is what brings about the reader's position within the text. This relationship is dialogic in nature, for in this way the text is constantly interrogating the reader and inviting response.

Iser talks only of a text-reader dialogue without any reference to the author. Nevertheless, given that it is, from his point of view, the text's structural elements that incite that dialogue, the question of author intentionality in such structuring comes once more to the fore. Tim Whitmarsh ${ }^{38}$, while noting that "the author's intention has long been a subject of scepticism among literary critics", observes that there are signs of renewed interest in "this malign figure", particularly in the work of Mikhail Bakhtin. However, he points out that Bakhtin distinguishes between the "primary author", the historically real human being who "consciously and physically composes the work", from the "secondary author" who is the "controlling consciousness within the text." While it is the primary author, then, who structures the reified text, it is the secondary author's voice we detect and respond to in reading. Thus, Whitmarsh concludes, "Bakhtin is surely right that any literary reading involves a kind of commerce with the absent author" and that "meaning emerges from the conversation between the two. Created neither at the point of transmission nor at the point of reception, it emerges provisionally through the ongoing process of shuttling back and forth between two consciousnesses." ${ }^{39}$ In summary then, we might say that, while it can be the primary author's intention that we should read the text alert to the potentialities for meaning generation within the text structure that he/she has created, the responses we make, and hence our interrogation of the text and the authorial consciousness within it, transcend any knowable intentionality on the primary author's part.

There remains, however, the need to consider the question of the "point of reception". While in the first instance this point might represent the moment of encounter between a reader and a text, such a moment can never be a pure singularity, but must be embedded within a historical, linguistic and cultural context. Otherwise, the

\footnotetext{
Iser (1978) 114.

Whitmarsh (2006) 108.

Whitmarsh (2006) 108.
} 
generation of meaning is effectively impossible, as meaning can only be created in relation to other prior-established knowledge. One must understand Latin to derive semantic meaning from Horace's poems. One needs at least some awareness of Roman history and culture to set those poems in a meaningful social context.

For a non-contemporaneous text, as well, the point of reception is rendered more complex by how far we as modern readers are seeking to interpret it from the point of view of its first readers, its potential "implied audience", as well as how far it speaks to us now within our own moment of time and culture, or at any other time in between. This hermeneutic question is particularly relevant for religious texts like the Bible or the Qur'an for which universal relevance is claimed. But it also must apply to some degree to all texts of past literature if they are to remain anything other than archaeological artefacts.

This question was addressed by Hans-Georg Gadamer in Truth and Method (1975). In analysing the way understanding and meaning develop, Gadamer adopted from Husserl the concept of the "horizon".$^{40}$ For every object that is the focus of attention, say an ancient text, Gadamer declares that there is also "a field of vision, a horizon" ${ }^{41}$ The horizon, which is a temporal rather than a spatial one, comprehends not only the object that is the focus of attention, but also what is not in focus, "a periphery of what is not objectified, but which nevertheless could become an intentional object, inside a different horizon." Gadamer explains this idea by saying it is always possible to call to someone's attention something they had not noticed, even though it was within their field of vision. In the same way, the concept of horizon implies that the artwork always means more than the author may have intended. But when such "surplus" meaning is drawn attention to by an interpreter, "this interpretation too has a horizon and is therefore open to (further) interpretation." 42

40 Gadamer's concept of "horizon" is thoroughly discussed by Weinsheimer (1985), notably on pp. 157, 182-83 and 210-11.

41 Weinsheimer (1985) 157.

42 Weinsheimer (1985) 157. 
Such a process carrying on over time creates a hermeneutic tradition against which other interpretations may be made. Thus, the horizon of the text is constantly expanding with each new interpretation. But, Gadamer points out, understanding does not mean simply adopting the perspective of the horizon of tradition. While one must place oneself within it to try to understand what it is saying, each new interpreter always has her/his own horizon which includes perspectives outside of the horizon of tradition. But through engagement with the horizon of tradition, what Gadamer terms a "fusion of horizons" (Horizontsverschmelzung) takes place, which then becomes the new horizon of tradition. "Understanding is always the fusion of these horizons supposedly existing in themselves." ${ }^{43}$

Gadamer developed the idea of the fusion of horizons in considering the hermeneutics of history, but he also applied it to textual hermeneutics, which he described as "coming into conversation with the text." ${ }^{44}$ But as Weinsheimer points out, ${ }^{45}$ in dialogue, questioning is reciprocal, and the same applies to dialogue with the text. Gadamer observes: "that a text handed down from tradition becomes the object of interpretation means already that it puts a question to the interpreter." ${ }^{46}$. Weinsheimer, commenting on this observation, states that "to open a text to discussion means to open its topic to the interpreter's contributions" and that "the reciprocity of questioning is realized when the interpreter puts a question to the text by which he in turn is put in question." 47 It is this dialectical interplay which constitutes Gadamer's "fusion of horizons" within the hermeneutics of textual interpretation. In this way, meaning is constantly being realized and so, says Gadamer, cannot be reduced to the author's intention.

The concept of "horizon" was further developed by Gadamer's pupil Hans Robert Jauss. Jauss derived from it the notion of the "horizon of expectations" (Erwartungshorizont) to characterize both the aesthetic and cultural-historical framework whose compass

\footnotetext{
43 Gadamer (1975) 273.

44 Gadamer (1975) 331.

45 Weinsheimer (1985) 157.

46 Gadamer (1975) 333.

47 Weinsheimer (1985) 210.
} 
the text calls to mind, as well as the cultural pre-understandings and anticipations that each reader brings to its reading. "A literary work, even when it appears to be new, does not present itself as something absolutely new in an informational vacuum", Jauss wrote in 1969, "but predisposes its audience to a very special kind of reception [...]. It awakens memories of that which was already read, brings readers to a specific emotional attitude, and [...] arouses expectations [...] which can then be maintained intact or altered, reoriented or even fulfilled ironically in the course of the reading." 48 The "horizon of expectation" that Jauss is referring to here, however, is that related more particularly to genre formation and evolution. Each new text, he says, evokes the horizon of expectations and rules familiar from earlier texts, which are then "varied, corrected, altered or even just reproduced. Variation and correction determine the scope, whereas alteration and reproduction determine the borders of genrestructure." 49 As a result of this process, the horizon of expectations for particular genres is constantly changing, such that a work's original "alterity", or distance from the expectations of its original audience, becomes absorbed into the general expectation once that newness has become integrated into the generic expectation. In consequence of this "horizonal change", says Jauss, works either become fixed as unchanging classics within a canon, or are experienced by later audiences as outmoded. ${ }^{50}$ The aesthetic value of a work then, in Jauss's view, lies in its artistic character not being always immediately perceptible within the "horizon of its first appearance." On the other hand, he also acknowledges that if the resistance that a new work poses is very great, it can require a long period of reception "to gather in that which was unexpected [...] within the first horizon". ${ }^{51}$

In his later work in reception theory, Jauss concentrated more particularly on the aesthetic reception of poetry. "In the poetic text," he wrote in a 1980 essay, 52 "aesthetic understanding is primarily directed as the process of perception; therefore

\footnotetext{
48 Jauss (1982) 23.

49 Jauss (1982) 23.

50 Jauss (1982) 26.

51 Jauss (1982) 35.

52 Translated (1982) as "The Poetic Text within the Change of Horizons of Reading".
} 
it is hermeneutically related to the horizon of expectations of the first reading." 53 However, it becomes clear from this article that by the "first reading" he is now meaning the first reading that any new reader undertakes of the work, not the reading by its first audience. The emphasis on this first reading as a perceptual reading means that the horizon of expectations referred to here is that internal to the poem, elicited by the structure, form and artistry of the text. It is only once the reader has perceived the dimensions of this horizon through the first reading that an interpretive horizon may emerge on second or subsequent readings. Jauss comments on this process thus:

The distinguishing of reflective interpretation from the perceptual understanding of a poetic text [...] is made possible through the self-evident horizonal structure of the experience of rereading. [...] Here the experience of the first reading becomes horizonal for the second one; what the reader received in the progressive horizon of aesthetic perception can be articulated as a theme in the retrospective horizon of interpretation. ${ }^{54}$ [my emphasis]

This primary role of perception - of the poetic effects created by the form, lexis, syntax and phonology of the text - that Jauss accords to its first reading is instrumental, he says, in generating the horizon "for a second, interpretive reading [which] at once opens up and delimits the space for possible concretizations. [...] From now on, the reader will seek and establish the still unfulfilled significance retrospectively, through a new reading, from the perspective of the fulfilled form, in return from the end to the beginning, from the whole to the particular. [my emphasis]"55

Jauss claims that this two-step reading approach of initial aesthetic perception preceding interpretive reception is also applicable to poetic texts distant in time, and criticises the hermeneutics of both classical and modern philologies which "sought to privilege historical understanding over aesthetic appreciation". ${ }^{56}$ Nevertheless he accepts that historicist-reconstructive readings have an important controlling function to play in that they "prevent the text from the past from being naively assimilated into the prejudices and expectations of the present, and thereby [...] allow the poetic text

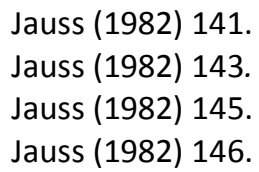


to be seen in its alterity." The "otherness" referred to here, though, is that which the text had for its original audience; the role of the reconstructive reading is to "seek out the questions to which the text was a response in its time."

However, the three elements of what Jauss denotes as the "triad of literary hermeneutics" - aesthetic perception, interpretive reception, historicist understanding - constitute an integrated process that is not necessarily uni-directional. As he summarizes in the final paragraph of his essay: ${ }^{57}$

The priority of aesthetic perception [...] has need of the horizon, but not the temporal priority, of the first reading: this horizon of aesthetic understanding may also be gained only in the course of rereading or with the help of historicist understanding. Aesthetic perception is no universal code with timeless validity, but rather, like all aesthetic experience, is intertwined with historical experience. [Jauss's emphasis].

Where then does reception theory leave response to the patterns of lexical repetition apparent in the Odes of Horace? Jauss's privileging of aesthetic perception as the starting point for reception analysis correlates neatly with the initial stimulus for this investigation, and his emphasis on the signification obtained through rereading and making retrospective connections with previously read elements offers a coherent theoretical framework within which to concretize potential meanings which may transcend the immediate meanings of the individual poems. Jauss however does not significantly engage the question of text-reader dialogue, and hence the place of the author, however defined, within this nexus, which Iser and other commentators like Whitmarsh ${ }^{58}$ and Kenneth Haynes ${ }^{59}$ still see as a factor to be taken into account, needs some further consideration in relation to Horace's work.

I propose in consequence to close this chapter by presenting an analysis of the last five poems of Odes 1, taking Jauss's theory as my broad guiding framework, before going on to consider the broader question in the remaining chapters.

57 Jauss (1982) 148, prior to demonstrating his approach in an extensive analysis of Baudelaire's poem Spleen.

58 Whitmarsh (2006) 108.

59 Haynes (2006) 50. 
The cluster Odes 1.34-38 has been chosen because it appears from initial observation to encompass a significant number of clearly noticeable repetitions and because of its prominent position at the end of Book 1. Below is a chart listing the full range of lexical repetitions, as earlier defined, which recur in this sequence of poems.

\begin{tabular}{|c|c|c|c|c|c|}
\hline Ode & 34 & 35 & 36 & 37 & 38 \\
\hline Metre & Alcaic & Alcaic & $4^{\text {th }}$ Asclepiad & Alcaic & Sapphic \\
\hline Length (lines) & 16 & 40 & 20 & 32 & 8 \\
\hline Headwords & 60 & 142 & 69 & 108 & 26 \\
\hline ago & egit & & actae & redegit & \\
\hline ambio & & ambit & ambitiosior & & \\
\hline asper & & asper & & asperas & \\
\hline bibo & & & & $\begin{array}{l}\text { bibendum/ } \\
\text { combiberet }\end{array}$ & bibentem \\
\hline Caesar & & Caesarem & & Caesar & \\
\hline colo & cultor & colit/colonus & & & \\
\hline corpus & & corpus & & corpore & \\
\hline deus & deus/deorum & deorum & deos & deorum & \\
\hline divido & dividens & & dividit & & \\
\hline do & dare & & & daret & \\
\hline dulcis & & & dulci & dulci & \\
\hline ferox & & ferox & & ferocior & \\
\hline fortuna & fortuna & & & fortuna & \\
\hline frequens & infrequens & frequens & & & \\
\hline funus & & funeribus & & funus & \\
\hline ignis & igni & & & ignibus & \\
\hline imperium & & imperium & & imperio & \\
\hline imus & ima & imo & & & \\
\hline invideo & invisi & & & invidens & \\
\hline mors & & mortale & & morte & \\
\hline muto & mutare & mutata & mutatae & & \\
\hline novus & & nova & novo & & \\
\hline nunc & nunc & & nunc & nunc $\times 3$ & \\
\hline paro & & & & parabat/reparavit & apparatus \\
\hline pes & & pede & pedum & pede & \\
\hline
\end{tabular}




\begin{tabular}{|c|c|c|c|c|c|}
\hline Ode & 34 & 35 & 36 & 37 & 38 \\
\hline pono & & posuisse & & deponet & \\
\hline potens & & potentis & & impotens & \\
\hline promo & promens & & promptae & depromere & \\
\hline puer & & & puertiae & & puer \\
\hline rego & & regis/regum & rege & regiam/regina & \\
\hline retro & retrorsum & retro & & & \\
\hline rosa & & & rosae & & rosa \\
\hline ruo & & proruas & & ruinas & \\
\hline saevus & & saeva & & saevis & \\
\hline Salii & & & Salium & Saliaribus & \\
\hline sodalis & & & sodalibus & sodales & \\
\hline sospes & & & sospes & sospes & \\
\hline spero & & Spes & & sperare & \\
\hline superbus & & superbos & & superbo & \\
\hline tellus & tellus & & & tellus & \\
\hline timeo & & timendum & & timores & \\
\hline tollo & sustulit & tollere & & & \\
\hline triumphus & & triumphos & & triumpho & \\
\hline ultimus & & ultimos & ultima & & \\
\hline velum & vela & velata & & & \\
\hline volo/are & volucrem & & & volantem & \\
\hline
\end{tabular}

The hermeneutic premise that underlies my reading of this sequence is that propounded by Jauss in "Thesis 4" of his 1969 article:

The reconstruction of the horizon of expectations in the face of which a work was created and received in the past enables one to pose questions that the text gave an answer to, and thereby to discover how the contemporary reader could have viewed and understood the work. ${ }^{60}$

This premise assumes an initial sequential and continuous reading (or hearing from recitation) of these five odes, under the constraints imposed by the ancient book-roll. It also assumes for the same reason that the earlier odes of Book 1 have already been encountered, and hence the initial audience's horizon of expectation for the reception

60 Jauss (1982) 28. 
of the work is already in process of development. In such a context, what aesthetic perceptions may have been open to a first audience?

From the point of view of form, the reader will already have observed the wide variation of metres employed by Horace over Book 1, and hence might perceive as a breach of this variatio the repetition of the Alcaic metre in odes 34 and 35, and again in ode 37. Use of this metre in consecutive poems occurs elsewhere in the book only at odes 16 and 17, but the clustering of Alcaics over three out of four poems is found only here. The relative brevity of the two other odes of the cluster (20 lines in ode 36,8 in ode 38 ) against the greater combined lengths of the other three (56 lines total for odes $34+35$, 32 for ode 37) may also reinforce this perception of Alcaic preponderance in this final group.

The common theme of the capriciousness of fortune is also readily perceptible on the first encounter with odes 34 and $35,{ }^{61}$ an occurrence which also breaks the book's general pattern of thematic and generic variatio between consecutive poems. Similarly, though the final three poems are thematically distinct, the openings of odes 36 and 37 project an imminent drinking party, while ode 38 closes on the image of the poet drinking quietly with his servant. But thematic linkage may have also been observed between the final three stanzas of ode 35 and the latter half of ode 37, which both refer to projected and actual military campaigns by Augustus against Eastern enemies.

Thus, a first reading may well elicit an impression that these five poems constitute at least to some extent an integrated whole rather than a series of separate pieces. Should the reader have also perceived certain of the patterns of lexical repetition as demonstrated in the above chart, then this impression of interconnection might be reinforced. This in turn could lead to questions of how such interconnection might be interpreted. Jauss's process of interpretive rereading would then allow potential

61 Observe the proximity (five lines apart) of lexical and semantic echoes between 1.34.12-13: valet ima summis / mutare at the end of 1.34, and 1.35.2-3: praesens vel imo tollere de gradu / mortale corpus at the beginning of 1.35 , where the implied subject in each case is "fortuna". 
answers to these questions to be generated. Let us then engage in such a process to see what meanings might emerge.

The most noticeable aspect is the number of recurrences between odes 35 and 37, involving 18 different headwords. Several of these particularly stand out by their usage in identical or closely similar syntactical or metrical locations. For example:

(a) $\quad 1.35 .3-4 \quad$ (praesens) ...... vel superbos / vertere funeribus triumphos.

1.37.31-31 (invidens) .... deduci superbo / non humilis mulier triumpho.

The epithet (superbus) modifies the same noun (triumphus) in both cases and their positioning is identical at the end of the third and fourth lines of their respective Alcaic stanzas.

(b) 1.35.2-3 praesens vel imo tollere de gradu /mortale corpus ...

1.37.27-29 ... ut atrum / corpore combiberet venenum / deliberata morte ferocior

While the syntactic associations are different in these pairs, the strong assonance of "mortale corpus in emphatic position in 1.35 .3 is reflected in the initial corpore of 1.37.28 and echoed by morte in 1.37.29.

(c) 1.35.14-16 ... neu populus frequens /ad arma cessantis, ad arma / concitet imperiumque frangat.

1.37.6-8 ... dum Capitolio / regina dementis ruinas / funus et imperio parabat.

In both cases imperium/imperio occupy identical metrical positions within the third line of the Alcaic stanza, with an echoing - at ending and - $a$ assonance on the penultimate, stressed syllable in the concluding verbs (frangat/parabat).

The perception of these lexical and metrical aesthetic effects may then incite the reader to link these two poems, thus inviting an interpretive reception by which the elements of the one inform the other. But retrospectively $C .1 .34$ is also drawn into this association, elicited in part by the lexical echo of fortuna (1.34.15; 1.37.11), and reinforced by the thematic centrality of the concept of fortune in $C .1 .35$, even though the lexeme itself is not used there. 
In C. 1.34 this concept was addressed in philosophical terms, but in 1.35 the idea is narrowed to its manifestation as an unpredictable political phenomenon. While still treated in general terms in 1.35 , the lexical echoes between 1.35 and 1.37 bring its focus on to the contemporary political situation of Rome, inviting the reader to draw whatever conclusion the text might suggest without directing any particular one. For the political interpretation is open to multiple readings. On the one hand, the capricious reversibility that characterizes Fortune, as declared by both $C .1 .34$ and 1.35, reads initially in 1.37 as applying to Cleopatra. The poem projects her ambition to smash the imperium of Rome (1.37.8), but instead it was her power that Fortune destroyed. Yet ironically, while the opening stanza of 1.35 declares that Fortune can turn the triumphs of the arrogant to dismal funerals, the closing stanza of 1.37 shows Cleopatra, by choosing her own death, denying Rome the expected arrogant triumph, but also through the manner of her death creating her own "proud triumph". ${ }^{62}$ This interpretation may then be strengthened for the retrospective reader by the recall that Horace at $C$. 1.35 .3 employs the unusual expression mortale corpus to characterize the humble individual whom fortune can raise to great heights, while at 1.37.28-29 these two lexemes are associated with Cleopatra's resolutely exposing her own body to death.

Once such interpretive reception is established through the aesthetic perception of these lexical recurrences, other layers of potential meaning are then opened up. Fortune is shown in C. 1.35.23-24 as able suddenly to desert great houses (potentis ... domos), rendering them impotens as it had to that of Cleopatra, though convinced fortune was on her side (fortuna dulci /ebria). But because this commentary that Fortune is always contingent comes immediately before the prayer that she should protect Caesar on his

62 The syntax of the final three lines of C. 1.37 (30-32): saevis Liburnis scilicet invidens / privata deduci superbo / non humilis mulier triumpho, allows for this alternate reading. While most commentators (e.g. Nisbet \& Hubbard [1970] 420; West [1995] 189), read deduci with triumpho, interpreting this as meaning that Cleopatra scorned (invidens) being led away to a triumph, they also observe that deduci with a dative is awkward. West notices that the epithet superbo is separated by hyperbaton from triumpho and that the "gap [...] is filled by 'no humble woman"” (190). But for him this simply creates a 'fortissimo' for triumpho. But surely the effect of this hyperbaton is to wrap Cleopatra in a "proud triumph", in the same way that in Odes 1.5.1 quis multa gracilis te puer in rosa, Pyrrha and her lover are presented as surrounded by many roses. Thus, we might read C. 1.37.30-32 with a comma after deduci, thus leaving mulier an appositional nominative, with non humilis governing an ablative superbo ... triumpho. 
forthcoming campaigns to Britain and the East, ${ }^{63}$ the poem carries the implicit warning that Fortune could turn against Caesar's house as well.

Inserted in between these two odes with their serious political themes, Odes 1.36 on the other hand appears on first reading to be more frivolous. For Nisbet and Hubbard, it seems little more than a conventional reworking of the theme of preparations for a convivium in which "Horace shows less than his usual skill in handling this theme" ${ }^{64}$ Yet Lowell Edmunds precisely identifies this poem, Odes 1.36, as an example of the "incompleteness of a Roman poem" whose "gaps or blanks and 'places of indeterminacy' have to be completed by the reader." ${ }^{\prime 65}$

What challenges a purely reductionist approach to this poem is the number of what seem significantly pointed lexical linkages between it and the others of this cluster. The recurrence chart reveals that $C$. 1.36 stands as a fulcrum between 1.35 and 1.37 . There are four common lexical pairs linking 1.35 and 1.36 and four between 1.36 and 1.37, while three headwords, deus, pes and rego are common to all three poems. We have noted also the thematic link between 1.36 and at least stanza 1 of 1.37 (party preparation) and the imagery of drinking that is common to both.

The recurrences relating $C .1 .35$ to 1.36 involve the lexemes ambio, muto, novus and ultimus. Of these, the first two are the most marked. Compare:

(d) muto

1.35.23-24 utcumque mutata potentis / veste domos inimica linquis

1.36.9-10 actae non alio rege puertiae / mutataeque simul togae

63 Nisbet \& Hubbard (1970) 387: the composition of Odes 1.35 is usually assigned to around 26 BCE, hence later than the Actium campaign, though some arguments would place it as early as $35 \mathrm{BCE}$. An interpretive reading in conjunction with $C .1 .37$ is more consistent with the former view.

64 Nisbet \& Hubbard (1970) 402.

65 Edmunds (2001) 100. In discussing the process by which the indeterminacy of a poem is completed, Edmunds quotes Iser, noting that "Iser added the dynamic interaction between text and reader as the means by which the text is completed." Edmunds however does not attempt any analysis of textreader interaction for Odes 1.36 in this particular study. 
Common here is the use of the feminine participle, which in each case qualifies a noun referring to clothing, metaphorically in C. 1.35 .23 (mutata ... veste) and metonymically in 1.36 .10 (mutatae ... togae). Yet a first reading may not find any particular significance in this parallel as the former is a figure characterizing a sudden change of Fortune, whereas the latter refers to the coming-of-age custom of boys changing their togas at puberty. However, the idea of changing social status is given greater weight through the echo of the earlier use of muto at $C$. 1.34.12-13: valet ima summis mutare, which, in conjunction with the $C .1 .35$ examples, injects a political dimension into the idea of change. In consequence, $C$. 1.36 hints at a concealed political reading, which we may find reinforced by rege in the previous line. The text thus challenges the reader to consider the identity of that rex whose toga was changed at the same time as that of the addressee, Numida. Superficially, this person is identified as Numida's best friend "Lamia", but, despite historicist conjectures, there is nothing in the poem that definitively links this to any particular Lamia of Horace's time. ${ }^{66}$ What the reference to the toga virilis ceremony does do for the temporal context of this poem, however, is project this ceremony back some twenty years in time from its putative moment of composition and hence invites conjecture as to who might have been considered "king of youth" at that time. ${ }^{67}$

The repetition "ultimos/ultima" is marked to the extent that both occupy the final position in their respective lines ( $C$ 1.35.29; 1.36.4), and both have geographic references, to Britain in C. 1.35 and to "Hesperia" in 1.36. The latter, while usually associated with Italy, especially in Virgil's Aeneid, in this case probably refers to Spain. ${ }^{68}$ The first usage is explicitly linked to a planned expedition of Augustus, but given the total lack of identification of Numida, ${ }^{69}$ the interpretation of the second is left potentially open.

We will leave aside for the moment any interpretation of the recurring pair ambit ( $C$. 1.35.5) and ambitiosior (1.36.20), except to note that these are the only two occurrences of the lexeme ambio in the whole Odes 1-3 corpus, and also the extremely strong attention that is drawn to the six-syllable comparative form of the cognate adjective as

66 Cf. Nisbet \& Hubbard (1970) 401.

67 No date of composition can be extrapolated from the composition, but there is nothing to indicate it lies outside of the main date range for the Odes (31-23 BCE). Hence a mid-20s date would push the toga-change ceremony back to the mid-40s BCE.

68 Nisbet \& Hubbard (1970) 402.

69 See Nisbet \& Hubbard 401, West (1995) 177-178 for discussion. Given the social prominence of Horace's other addressees, to address a poem three from the end of the book to someone undistinguishable is curious, and there are suggestions "Numida" may be a poetic invention intended to refer to someone else. 
anticipating the coming echo of $C$. 1.36 .20 and posing the question of an interpretive linkage.

What attracts attention between $C .1 .36$ and 1.37 are the three recurrent pairs that begin with "s-": Salium (1.36.12) - Saliaribus (1.37.2); sodalibus (1.36.5) - sodales (1.37.4); sospes (1.36.4) - sospes (1.37.13). While the first two pairs can on the primary level be explained by the parallel preparations for a celebratory feast in the style of the Salii guild, the strongly alliterative sibilant echoes: "sal-", "sod-", "sos-" tie the two poems strongly together and incite their reading in conjunction with each other. Doing so will also then bring attention to the common imagery of unrestrained drinking found in each, and to the fact that, dominating the men in this activity, is the increasingly strongly focused figure of a woman. Though unnamed, in C. 1.37 the woman is obviously Cleopatra, while in C. 1.36 she is presented as a courtesan named Damalis. The two women come to occupy the poetic narrative in their respective odes so prominently that the key men mentioned, Lamia at $C$. 1.36 .7 and Caesar at $C$. 1.37.16, fade completely from view by the end of each poem. But there is one, unnamed male character who is the centre of Damalis's attention and about whom she is "more closely wound than amorous ivy": lascivis hederis ambitiosior. The compelling interpretive conclusion to be drawn from the similar intertwining of the two poems is that Damalis ${ }^{70}$ evokes Cleopatra, which in turn invites the interpretation that the unnamed lover ${ }^{71}$ represents Antony, the great missing figure from the Actium narrative of $C$. 1.37.

To return then to ambitiosior, the adjective carries the basic sense of "winding about," "entwining", then by extension, "fawning upon in the search of favour", though not yet quite the modern sense of "ambitious". Its origin is in the verb ambio, used mainly in Latin in the political sense of canvassing for votes. But in $C$. 1.35.5 it is applied to those who seek the favour of Fortune: te praeter ambit .... Among Fortune's suppliants are

70 Note that damalis in Greek means 'heifer', bringing to mind the image of the cow-goddess Hathor, who was also the goddess of womanly love, and a leading member of the Pharaonic pantheon that the Ptolemies adopted.

71 Nisbet \& Hubbard (1970) 406 assert that "Numida is hinted at" as the lover. But as Numida effectively disappears from the focus of the poem as the narrative perspective changes after line 10 , there is no textual indicator to show it is he who is the object of Damalis' attention. 
listed the regum matres barbarorum but equally Latium ferox. Cleopatra's supplication to the goddess proved fruitless. ${ }^{72}$ But in the process of her ill-fortune she became ferocior 1.37.29 (the comparative form echoing the ambitiosior of 1.36.20). He in Latium who has eyes to read, Horace may be saying, let him read.

When we consider the brief final ode $C .1 .38$, what clearly ties it to the preceding group is the strongly marked echo between $C$. 1.37 .1 bibendum and $C .1 .38 .8$ bibentem, the last word of this poem and hence of the whole of Book 1. It is the very similarity of their orthographic forms that brings attention to their functional difference. The gerund bibendum is forward-looking, indicating a drinking activity that the poetic voice is now urging should take place, while the present participle bibentem indicates that the drinking is now under way. $\ln C$. 1.37, those who are to drink are not specified. In $C .1 .38$, on the other hand, the drinker is the poet, who invites his servant to drink with him in an environment of private intimacy. The receptive interpretation activated by this juxtaposition, particularly in view of the prominent position of ode 38 at the end of Book 1 , is that what the poet is inviting his audience to taste with him is in fact the quality and subtlety of his integrated book of poems. ${ }^{73}$ The Caecubum has now been opened and poured for their appreciation. However, the final participial bibentem suggests that this will not be the last such pleasure, and the reader may anticipate further invitations in the following books.

To conclude, I do not claim that this interpretation is the definitive meaning intended by the primary author Horace. That is unverifiable. But I contend equally that the interpretation is not arbitrary, as it arises out of a text-reader dialogue of the kind theorized by Iser. What has stimulated this dialogue are the disturbances in the reading flow created by the observed patterns of lexical recurrences between the poems. The aesthetic perception of these has consequently prompted interpretive re-readings of these texts in the Jaussian manner whereby meanings of the individual odes are

72 At $C$. 1.35.6, the goddess is saluted as dominam aequoris. Cleopatra's attempt to rival Fortune in this role met with disaster: vix una navis sospes ab ignibus (1.37.13).

73 The attribution of the figurative object of "my verse" to the verb bibo here is supported by such a usage in Odes 2.13.32 where Horace imagines the Underworld throng "drinking in" (bibit aure) the songs of Alcaeus. 
concretized not only from within their own bounds, but both retrospectively and prospectively in association with their contiguous neighbours. Hence, meaning generation emerges from a constantly evolving interaction between the poems as the reader perceives the connections, creating a play of mutually reflecting harmonies within the greater structure of the whole poetry book.

Where then does that leave the concept of authorial intention and the role of the poet? Is the mind of Horace discernible within his poetry? This is the question to which the remainder of the thesis will be directed. 


\section{Chapter 3}

\section{The Development of an Audience}

In what sense can we discuss authorial intention in relation to Horace? Indeed, when we refer to "Horace" in the context of a literary analysis of those works, who are we talking about? The historical personage, Quintus Horatius Flaccus, who lived between 65 and 8 $\mathrm{BCE}$ ? Or the particular persona whom we encounter in the poetry composed by that individual? Before we can examine Horace's intentions, therefore, we need to clarify who and what we mean by that name. This task is made more difficult by the fact that almost all we know about the historical Horace is what he tells of himself in his own works. ${ }^{74}$ Even the Vita Horati attributed to Suetonius draws essentially from these, adding little more than some comments about Horace's relationship in his later years with Augustus, drawn from the emperor's own writings. But how important is knowledge of Horace's biography for the interpretation of his works?

Michèle Lowrie, for one, prefers to disregard the historical person entirely, asserting that for her "Horace stands for everything that has come down to us under his name." Thus, "Horace" is simply a "metonymy for [his] texts". ${ }^{75}$ But while this approach may be suitable for poets who do not directly project an authorial persona into their poems, it is a more complex issue for Horace, where a clear authorial voice is omnipresent throughout his whole opus. Furthermore, with Horace we need to distinguish the firstperson authorial voice from the retrospective autobiographical representation of himself that is presented in some poems ${ }^{76}$. Randall McNeill takes this further, observing that "[Horace] does more than shape the way he presents himself; he shapes the way others (including ourselves) respond to these self-presentations by tailoring his remarks and addresses to the specific interests, tastes and expectations of a surprisingly wide array of readers and audience." ${ }^{17}$

74 Gowers (2012) 2.

75 Lowrie (1997) 7.

76 E.g. the presentation of himself as timid and tongue-tied when first introduced to Maecenas in Sat. 1.6.56ff., or as sweating with embarrassment when trying to get rid of the importunate pest in Sat. 1.9 .

77 McNeill (2001) 5-6. 
Thus, even if we set aside the historical "primary author", the "secondary author" present within that author's texts manifests himself in multiple forms which can also shift between themselves within the context of a single poem. Among these forms the following may distinguished:

(i) a narrative voice, itself divided between being disengaged and objective, as in Satires 1.7 and 1.8, in Epodes 5 or Odes 1.15 and 3.27.25-76, or engaged and autobiographical, as in Satires 1.5 and 1.9;

(ii) a diegetic voice (dramatic monologue), as in Epodes 12 and 17, and Odes 1.27 and 1.36;

(iii) a self-referential voice, whether self-analytical as in Satires 1.4.104-146, selfcommendatory as at Odes 1.31, 2.20 and 3.30, and Epistles 1.19.21-49 or autobiographical in Satires 1.6.45-88, Odes 3.4.5-28 or Epistles 1.20.19-28;

(iv) an interlocutory voice engaging a named or implicit addressee, as in the majority of Satires 2 and most of the Epodes and Odes, along with the Epistles and the Ars Poetica;

(v) a voice of commentary directed to a diffuse or general audience, as in Satires 1.1 to 1.4 and 1.10 ;

(vi) a celebratory voice, as in Epodes 9 and Odes 1.37;

(vii) a prophetic voice of warning, as in Epodes 16, Odes 1.2, 1.35 and throughout the Roman Odes.

Behind all of these voices is the "controlling consciousness" that Bakhtin identified as the functional mode of the secondary author.

When considering authorial intention, then, can any interface be established between the real-life intentions of the primary author in composing the work and those that the secondary author expresses or intimates within the text? This is a complex issue which Edmunds has addressed in relation to intertextuality. He asks, "what links poetic [intertextual] reference, or the avoidance of it, to the poet? Presumably it is the poet's 
intention to which such phenomena are to be assigned."78 Edmunds goes on to assert that indeed "Roman poets had intentions for their poems", whether "to please a patron" or their "often evident intention to say something about Rome."79 "Intentions of this kind," he continues, "can be thought of as prior to or distinct from the poems in which they are embodied." 80 We might label these therefore as "external intentions".

But how were (or now are) such intentions "evident"? For most ancient poets there are few other sources external to their own work to corroborate them. Hence, a reader's perception of an intention can be derived only from within the poem itself, which Edmunds refers to as "internal intention" 81 and which for him is "only the 'intention' of the speaker or persona". He ultimately concludes, "The intention of the poet is useless".

But is that absolutely so? The primary and secondary poets are not distinct entities but two avatars of the one persona. It is just that the one operates within the 'real' timebound world of history, while the other does so within the diegetic and timeless world of the artwork. In return, a similar process operates for the reader, who also occupies two worlds. Upon entering the textual world, she or he may then perceive within the text expressions of intentionality on the part of the secondary author. It is then open to her or him to reconstruct from these certain real-world intentions on the part of the primary author. ${ }^{82}$ There is no way of corroborating how far this reconstruction does in fact correspond to the historical poet's actual intentions. But, if derived in the coherent dialogic manner discussed in the previous chapter, there is nothing to gainsay it either.

It is therefore within these parameters that I will discuss the intent, or perhaps more appropriately the involvement, of "Horace" within the work of the real poet of that name. That intent I see overall as being to engage the reader of his poetry in an ongoing

78 Edmunds (2001) 19. Edmunds quotes Richard Thomas (1986): Virgil "seems, after the Eclogues, to have avoided polemical or other references to contemporary poets".

79 Edmunds supports this assertion by affirming that "Roman poets were understood [by their audience] to be intending to say something", pointing in evidence to Augustus's reaction to Ovid's Ars Amatoria that the poet was promoting adultery.

80 Edmunds (2001) 20.

81 Edmunds (2001) 37.

82 That for example the historical Horace wished to promote the moral regeneration of Rome after the civil wars. 
dialogue about matters that the work itself identifies. That dialogue takes place within the domain of text. While therefore I will refrain henceforth from putting "Horace" in inverted commas, I will use the name in the sense of the avatar of the poet who is present as an interlocutor within the textual realm of his works.

Quite when Horace initiated his career as a poet remains unclear. Brought to Rome by his father to obtain a better education than that available in his provincial home town of Venusia, he very probably dabbled in verse composition while at school, as many educated young Romans did, ${ }^{83}$ following the models of the Latin poets of the $3^{\text {rd }}$ and $2^{\text {nd }}$ century that he recalls having to learn by heart. ${ }^{84}$ This skill may have been developed further during his study in Athens; in Satires 1.10.31 he mentions essaying verse in Greek.

But doubt has been cast on Horace's declaration in Epistles 2.2.49-52 that he was driven by poverty to write verse for a living when he returned from exile after Philippi to find his father's small estate confiscated. ${ }^{85}$ White argues ${ }^{86}$ that the only activity poets were paid for in $1^{\text {st }}$ century BCE Rome was writing for the stage, which Horace disclaims. ${ }^{87}$ White asserts that Horace's father must in fact have acquired enough wealth to be admitted to the equestrian order, which would also account for how his son could be commissioned as a military tribune in Brutus's forces. Further, that even after the confiscation of his landed property, Horace must have retained, or obtained, enough capital to purchase the position of scriba quaestoris in the Treasury, ${ }^{88}$ and to maintain equestrian status, which required a substantial income. ${ }^{89}$ Thus Horace's claim to poverty as the impulse for his poetic career is, in James Zetzel's view, following Fraenkel and others, "not to be taken seriously." ${ }^{90}$ But if this is so, then why does he so persistently

\footnotetext{
83 White (1982) 63.

84 In Epistles 2.1.50-62, Horace names the poets studied as Livius Andronicus, Ennius, Naevius, Pacuvius, Accius, Plautus, Caecilius and Terence.

85 unde simul primum me dimisere Philippi / decisis humilem pennis inopemque paterni / et laris et fundi, paupertas impulit audax / ut versus facerem.

86 White (1993) 6. He quotes Ovid, Tristia 2.507: scaena est lucrosa poetae as evidence.

87 Sat. 1.37-39: haec ego ludo / quae neque ... / nec redeant iterum atque interum spectanda theatris.

88 After Suetonius's affirmation in Vita Horati: scriptum quaestorium comparavit.

89 For a discussion of Horace's equestrian status see Armstrong (2010), 12-21.

90 Zetzel (1982) 89. See Fraenkel (1957) 13-14 on Horace's claimed poverty post-Philippi.
} 
make this claim, from the Satires to the Odes to the late Epistles? It is a question I will return to shortly.

Whatever the initial drive to creative writing, Horace must, by around $38 \mathrm{BCE}$, have been composing verse of sufficient quality and moving in the appropriate social circles for Virgil and Varius Rufus to recognize his talent, and be prepared to introduce him to their patron Maecenas. ${ }^{91}$ It was one thing, however, to aspire to a poetic career, and even to show talent. It was quite another to establish a reputation that would command an audience. The scenario that I shall elaborate regarding how Horace achieved this derives essentially from Satires 1, supported occasionally by the Epistles. The "Horace" of this context, therefore, is both the authorial persona and objective representation of himself that is projected through those works. How far this corresponds to the historical poet's early circumstances and ambition cannot otherwise be determined. But this also removes the need to test the truth-value of that persona's statements.

The years in which Horace putatively began his career, in the late 40s and early 30 s BCE, were ones of considerable political, social and literary transition. ${ }^{92}$ By the year 40 , the great figures of the last generation of the Republic were either dead or nearing the end of their active careers. Of the poets of that generation, Lucretius had died around 55, Catullus around 54 and Licinius Calvus in 47, while the neoteric "revolution"93 of which the latter two were leading members had effectively worked itself out. There is in fact no extant Latin poetry, other than fragments, from the period 54-42 BCE and no testimony of major works from that period that may have been lost.

Nevertheless the change in poetic taste that was associated with the neoteric revolution - preference for brevity of form, metrical novelty and extreme care in composition that arose out of admiration for the culture and poetry of third-century BCE Alexandria survived its first practitioners to become the prevalent aesthetic of the emerging

91 Sat. 1.6.55. Conte (1994) 292 projects this introduction at "around the middle of 38 B.C.", Gowers (2012) 3 at "around 39/8 B.C."

92 See Conte (1994) $249 f f$.

93 So characterized by Conte (1994) 137. 
Augustan period. This mid-century attraction to Alexandrianism has generally been attributed to the influence of the Greek poet Parthenius of Nicaea who was brought to Rome after being taken prisoner and enslaved in the Mithridatic wars around 72 BCE. Once there he was freed and became a teacher of poetry. Parthenius came to know Catullus and other neoteric poets ${ }^{94}$ and may have influenced them through his preference for the Alexandrian poets, particularly Callimachus. ${ }^{95}$ Ancient sources also linked Parthenius to Virgil and to Virgil's contemporary Cornelius Gallus. ${ }^{96}$

However uncertain these particular associations may be, it seems that appreciation for the Alexandrian aesthetic did straddle the gap between the neoterics and the group of younger poets who emerged near the end of the 40s. By then, Virgil was composing his Eclogues following models drawn from Callimachus and Theocritus, while Cornelius Gallus was developing the form of the Latin elegy, seemingly under the influence of Parthenius. ${ }^{97}$ Gallus was equally the friend of Virgil, who dedicated his $10^{\text {th }}$ Eclogue to him.

It was thus within an aesthetic environment of appreciation for Alexandrian poetics that Horace initiated his career. The challenge for him personally would have been to elaborate his own particular form and style if he was to claim a place of note within the newly emerging poetic field. But in his case, more pressing still was the need to generate an audience. For his "outsider" status, as the son of a freedman functionary from the provinces, compounded by his having chosen the "wrong side" in the recent civil wars, meant that he would not have enjoyed immediate acceptance by the well-educated literary classes of Rome. It is his pursuit of and cultivation of an audience that would first accept him as worthy of being read and then come to appreciate the artistry of his

94 Notably Helvius Cinna, whom some identify with the Cinna who brought Parthenius to Rome: Conte (1994) 141.

95 Francese (2001) 37, while supporting this assumption, recognizes that firm evidence for it is slight.

96 Macrobius says Virgil employed Parthenius as a tutor in Greek literature, while Parthenius dedicated to Gallus his extant "romance novel" Erotika Pathemata: Francese (2001) 27. Francese asserts (90) that this latter work "is the most valuable and informative document we have for reconstructing Parthenius's distinctive poetics".

97 Conte (1994) 325, affirms Gallus as "the heir - through Euphorion and Parthenius - of Alexandrian poetry, [which] thus confirms his great significance as a mediator between neoterism and Augustan elegy". 
composition that is the underlying theme of his first published poetic work, Satires Book 1.98

For the manner of poetry's reception was also in a state of transition in Rome in the later first century. Over the previous hundred years, its most common form had been through public recitations of the poets, which drew great crowds. ${ }^{99}$ Suetonius reports that the persistent public taste was for the "classics" of the past, notably the epics of Ennius and Naevius, but this did not prevent contemporary aspiring poets from also declaiming their own verses in public places like the Forum or the Baths. ${ }^{100}$ However, such informal recitations need to be distinguished from more organized recitals, ranging from casual get-togethers of poets to compare verses, ${ }^{101}$ to poetry competitions before a critic or judge, or possibly within a poets' guild, ${ }^{102}$ to recitations of early drafts of works before learned and supportive friends for the purpose of generating constructive criticism, ${ }^{103}$ culminating in public or semi-public readings of finished works before select audiences.

Works were also read to the "well-off" by slave readers; readings were a recognized form of entertainment at dinner-parties. ${ }^{104}$ On the other hand, there is uncertainty about when organized public recitation by authors themselves became an established cultural phenomenon in Rome. Gordon Williams affirms that this practice began only with the opening of Rome's first public library by Asinius Pollio in 39 BCE. ${ }^{105}$ This view is nuanced by Elizabeth Rawson who states that in effect public recitation by authors did not begin with Pollio, although acknowledging that the role played by lectures and readings before this time should not be exaggerated, as Cicero's letters hardly refer to them. ${ }^{106}$

98 Feeney (2009) 17 identifies "meta-reception - how his reception becomes one of his themes", as an "abiding preoccupation" of Horace's early work, notably Satires 1.

99 Wiseman (1982) 36, quoting Suetonius (Gramm. 2.4).

100 As Horace Sat. 1.4.74-75: in medio qui / scripta foro recitent multi quique lavantes.

101 As in Catullus 50.1-4, evoking a poetry-writing session with Licinius Calvus.

102 White (1993) 57, commenting on Sat. 1.10.37-38: haec ego ludo / quae neque in aede sonent certantia iudice Tarpa.

103 Horace recommends this process in the Ars Poetica 438-452. Pliny the Younger, Epist. 7.17 also comments on the value of such trial runs of pieces before they are finally presented in public.

104 Rawson (1985) 51. See also White (1993) 59.

105 Williams (1982) 9.

106 Rawson (1985) 52. 
A fair conclusion may be that from around the beginning of Horace's career, such formal recitations by poets before select audiences, generally sponsored by a patron, were gradually becoming established as cultural events. White observes that "sponsored readings elevated the importance of poetry by identifying it as something in which society's most important people invested their time."107 Nevertheless, the poets determined what was to be read and decided when it was ready for public dissemination. ${ }^{108}$

There was, however, another form of literary reception that was spreading in the same period: private individual reading. Edmunds argues that private reading for aesthetic experience was a new development for Roman literature in the first century, to the extent that poets could now expect private reading to be "the primary reception of their work."109 Access to books was certainly increasing, with the development of the booksellers' trade and the opening of Pollio's library in 39 and that by Augustus in the temple of Apollo in $28 .{ }^{110}$ In addition, private individuals were building up their own libraries. ${ }^{111}$ As to the process of personal reading, the ancient book-roll effectively imposed reading continuity. Cicero's writings show that the impact of the Greek reading culture on the educated Roman reader was significant and induced a close and accurate approach to reading. For Latin poetry as well, the book became the central literary entity, with readers being led to give attention to how items within a single book related to each other. ${ }^{112}$

\footnotetext{
107 White (1993) 61, drawing his evidence from Pliny, Epist. 6.15.2.

108 Whether Horace ever took part in public recitation is unclear. He declares his unwillingness to recite in the theatre at Epist. 1.19.41-42, but in a tone of self-deprecation and disdain for the popular audience: spissis indigna theatris / scripta pudet recitare. Ovid, on the other hand, at Tristia 4.10.4950 recalls hearing numerosus Horatius reciting his carmina, hence possibly the Odes. But the setting for this recitation is not given.

109 Edmunds (2001) 108, 110. See also Hutchinson (2008) 38, though Rawson (1985) 45 had earlier been more hesitant, stating "we have little evidence of [...] reading habits, even of the upper classes."

110 Kilgour (1998) 43. Horace mentions his books on sale at the Sosii brothers' bookshop (Epist. 1.20.2).

111 Hutchinson (2008) 36. Horace refers jokingly to the collection built up, then exchanged for Spanish armour, by Iccius in Odes 1.29.13-15.

112 Hutchinson (2008) 40.
} 
Whatever Horace the primary author's actual practice may have been, his poetic persona in Satires 1 rejects public recitation as a vector for his reception on the grounds that the preference of the vulgus is for the bombast delivered by populist poets and that many do not appreciate the satiric genre that he has chosen. ${ }^{113}$ He goes on to assert at Sat. 1.4.73-74 that in fact he is unwilling to recite to anyone anywhere, even to friends, unless prevailed upon by the latter. ${ }^{114}$ But this claimed unwillingness to recite his verse needs to be set within the interpretive context of the whole ten-poem Satires Book 1. Recitation is rejected because it is frequently associated with verse that is loosely and rapidly composed without care for artistry, and hence, audiences are not trained to look for such in oral performances. This is Horace's criticism of Lucilius' prolixity at Sat. 1.4.913, which, he adds at Sat. 1.10.56-58, prevents the earlier poet's qualities from showing through even when he is read. The subtleties of poetry, Horace suggests, can only be perceived by careful reading, a point he makes through superficial self-deprecation at Sat. 1.4.39-42, where he declares he does not rank himself among those he would recognize as poets because the satiric genre he is writing in is too close to normal speech (sermo). ${ }^{115}$ Yet given that Satires 1.4 has been included within the whole carefully constructed poetry book, its readers are implicitly invited not to take this statement at face value, but rather to examine their own prejudices as to what might comprise poetry, and to allow that sermones of the Horatian type can indeed meet the criterion.

In this way, Horace envisages poet and reader linked by a sort of poetic contract, which he initially outlines in Satires 1.10 and elaborates further in his later Epistles. Poetry should be such, he affirms, that it invites re-reading. ${ }^{116}$ In furtherance of this aim, a poet must often use his eraser: saepe stilum vertas, (Sat. 1.10.72) and engage in constant

${ }^{113}$ Sat. 1.4.23-25. The same lines also contain the assertion that no-one reads him either: mea nemo / scripta legat. Brown (1993) 129n. explains this by stating that at first Horace was not writing for publication, comparing this line with 1.4.71: nulla taberna meos habeat neque pila libellos. Brown comments that, though both claims are disingenuous, Horace's central claim that he is not seeking a wide audience remains valid.

114 nec recito cuiquam nisi amicis, idque coactus / non ubivis coramve quibuslibet.

115 neque enim concludere versum / dixeris esse satis; neque si qui scribat uti nos / sermoni propriora, putes hunc esse poetam. This point is made again in more positive fashion at Sat. 1.10.16-19 in relation to perceiving the subtle humour of the masters of the Old Comedy that is totally missed by Hermogenes, a prominent singer who is a frequent butt of Horace's satire: illi scripta quibus comoedia prisca viris est / hoc stabant, hoc sunt imitandi: quos neque pulcher / Hermogenes umquam legit [...].

116 Sat. 1.10.72-73: iterum quae digna legi sint / scripturus. 
revision, self-criticism and ruthlessness in weeding out anything that falls short of the highest literary and linguistic quality. ${ }^{117}$

But the reader's part in this contract is also important, as Horace observes to Augustus in Epistles 2.1.214-218:

verum age et his, qui se lectori credere malunt quam spectatoris fastidia ferre superbi, curam redde brevem, si munus Apolline dignum vis complere et vatibus addere calcar, ut studio maiore petant Helicona virentem.

But come, upon those, too, who prefer to put themselves in a reader's hands, rather than brook the disdain of a scornful spectator, bestow a moment's attention, if you wish to fill with volumes that gift so worthy of Apollo and spur on our bards to seek with greater zeal Helicon's verdant lawns. (trans. Fairclough 1961)

Here, Horace is encouraging Augustus to select for the new Apolline library authors who write principally to be read as well as those who write for the theatre. The "gift worthy of Apollo", however, may also be construed as referring to the gift of poetic talent, and the opportunity to be included in the library and thus be read will add starch to poets' efforts to produce work of the highest quality. But, as he has mentioned in Sat. 1.10.73$74,{ }^{118}$ poets striving for this quality have to accept that such an audience is likely to be small.

The first task facing Horace himself, as represented in Satires 1, was therefore to develop such a committed audience with whom he could build a contractual relationship based on quality and appreciation. It is within this context that we may interpret the poet's creative persona insisting so much on his poverty and his low social origins, and the importance he attributes to his relationship with Maecenas. For it should be borne in mind that, by the time the 10-poem volume was published around $36 / 35 \mathrm{BCE},{ }^{119}$ Horace had already gathered an initial audience consisting of the intimates of Maecenas's

117 Epist. 2.2.109-110: at qui legitimum cupiet fecisse poema, / cum tabulis animum censoris sumet honesti. In similar vein, Ars P. 386-390 urges initial drafts of poems to be put aside for some time, to enable them to be revised with fresh eyes, before a final version is published.

118 neque te ut miretur turba labores, / contentus paucis lectoribus.

119 Gowers (2012) 1. 
literary circle, whom he lists by name in Sat. 1.10.81-84. But he is also aware that others outside of this circle are reading him, mentioning Pollio and Messalla Corvinus in particular as two other significant literary patrons. To these he adds "various (unnamed) others" whom he "prudently passes over". Here (Sat. 1.10.87) the emphatic assonance in -os: compluris alios doctos ego quos et amicos, in the midst of whom he includes himself (ego), graphically describes Horace's desire to establish a literary relationship with readers who are both knowledgeable (docti) and sympathetic (amici). These alii ${ }^{120}$ are then included with the previously named readers as being those among whom he particularly hopes his verses "such as they are", might find favour. ${ }^{121}$ As for the model for such a creative and appreciative association, the frequent evocation of Horace's own relationship with Maecenas throughout Book 1 of the Satires suggests it is to be found there.

Maecenas's patronage of Horace has been comprehensively analysed. ${ }^{122}$ Most commentators agree with Bowditch that, among the Roman aristocratic elite, where the class divide between a benefactor and his protégé was narrow, such patronage was reckoned as a form of amicitia rather than as a hierarchical patron-client relationship which, says Cicero, was a socially deadly status to assert in such circumstances. ${ }^{123}$ This is indeed how Horace describes the relationship with Maecenas into which he was ushered by Virgil and Varius. ${ }^{124}$ Amicitia of this sort did not however assume exact social equality, ${ }^{125}$ but rather an asymmetrical relationship of exchange "in the sense that the

120 McNeill (2001) 37-38 describes Horace's actual and potential readership at the time of publication of the Satires in the form of five concentric circles. While Maecenas and Horace's named friends occupy the first two circles, McNeill places the alii of Sat. 1.10.87 in the third, being "members of an elevated and erudite social stratum whom Horace needed to reach to ensure his broad acceptance as a poet." The fourth and fifth rings comprise potential reader progressively further removed from his literary and social circle.

121 Sat. 1.10.88-89: quibus haec, sint qualiacumque / adridere velim. Gowers (2012) 337 detects a "Catullan shrug" here, echoing, along with the poem's final word libello (1.10.92), II. 8-9 of Catullus 1: quidquid hoc libelli / qualecumque, but treats the allusion simply as "another cliché of neoteric modesty."

122 Most recently by Zetzel (1982), DuQuesnay (1984), White (1993), Lyne (1995), Oliensis (1998), McNeill (2001) and Bowditch (2001).

123 Cicero, De Officiis 2.69: patrocinio vero se usos aut clientes appellari mortis instar putant.

124 Note the emphatic repetition of te ... amicum at Sat. 1.6.50 and 53.

125 Lyne (1995) 15. For an examination of the amicitia relationship between Horace and Maecenas, see Williams (2012) 191-97. 
two parties offered different kinds of goods and services." ${ }^{126}$ As for literary patronage, in Bowditch's analysis it differed from other social amicitia only to the extent of offering opportunity for exchange at the artistic level as well as the material or social. ${ }^{127}$ That Maecenas extended the latter to Horace is effectively certain ${ }^{128}$, while in his turn the poet ensured his patron's lasting literary fame by dedicating several of his works to him.

From the reader-reception point of view, however, the presentation of the HoraceMaecenas amicitia in the Satires invites another level of interpretation. The poetic voice of Horace is at pains to point up the initial inequality of the relationship, by emphasizing his lowly social origins, twice repeating the phrase libertino patre natus (Sat. 1.6.45-46) to underline the taunts he had been subjected to; his father was "poor" and had only a "Iean plot of land": macro pauper agello (Sat. 1.6.71). He confesses to have been tonguetied at the first interview with Maecenas (Sat. 1.6.56), and that he had to wait nine months before being fully admitted to the ranks of his patron's friends. ${ }^{129}$ He then goes on at some length (Sat. 1.6.64-88) to praise his father who, despite his alleged poverty, had brought his son up under a strict code of morality and found enough money to bring him to Rome for his education.

Poetically speaking, what could be the point of all this? Certainly there is an acknowledgement of the benevolence accorded Horace by both his father and by Maecenas, but his exaggerated self-deprecation on the one hand and self-puffery on the other smacks on the surface level of ingratiation and conceit. ${ }^{130}$ Yet that a poet of Horace's acuity would not have realised this when preparing his collection to be published strains credibility. Hence careful readers are challenged by the text to answer that question themselves. An initial response might be that quality in art is not determined by social factors ${ }^{131}$ but may arise in any conditions. For this to be recognized,

\footnotetext{
126 Bowditch, (2001) 22, quoting Richard Saller (1982), Personal Patronage under the Early Empire (Cambridge) 1.

127 Bowditch (2001) 23.

128 Gowers (2012) 3 is uncertain about the Maecenas' supposed gift of the Sabine farm.

129 in amicorum numero: Sat. 1.6.62.

130 See particularly Sat. 1.6.65-70 and 1.6.130-31.

131 This may assist the interpretation of Horace's persistent claim to "poverty". Compare Odes 2.18 where the poet, after disclaiming wealthy possessions, asserts (II. 9-11): at fides et ingeni / benigna vena est, pauperemque dives / me petit. The close association made here between artistic talent and poverty,
} 
however, requires training, commitment to sound values and persistence on the part of the artist, and a perspicacity and generosity that surmounts prejudice on the part of the audience. By thus presenting the conditions and processes necessary for his acceptance into Maecenas's circle, Horace is also indirectly indicating what is required of those who would become his amici within an environment of rigorous but sympathetic discrimination.

This model, thus adumbrated in Sat. 1.6, is then fully fleshed out in the final two poems of the book, firstly through the comic anecdote of Horace's encounter with the "pest" in Sat. 1.9 who wants to be introduced to Maecenas. Beneath its surface-level levity, this tale is inviting the attentive reader to recall both Horace's own introduction to Maecenas in Sat. 1.6 as well as his own reported ineptness in Sat. 1.3 of pestering Maecenas with chatter while the latter was reading. ${ }^{132}$ As Gowers recognizes, "[the pest] is Horace's doppelgänger, just some stages behind in the game." ${ }^{133}$ These textual associations are reinforced by the echo in the first line of Sat. 1.9: sicut meus est mos /, of Sat. 1.6.60-61: respondes, ut tuus est mos / pauca, the non-committal response of Maecenas to Horace stammering self-presentation. But now it is Horace who is potentially able to arrange an introduction. Instead, he is left sweating in embarrassment (1.9.10) at his unwillingness to comply.

The clue to this tale's interpretation can be found in the revelation that the "pest" is a would-be poet and "intellectual": docti sumus (Sat. 1.9.7) ${ }^{134}$ who is seeking entrance to the amicitia circle alongside Viscus and Varius on the strength of his confident claim: "who can write more verses than I, or more quickly?" (Sat. 1.9.23-24). But this claim refers back to all the worst faults in poets that Horace had identified in earlier satires, a

and the strong lexical juxtaposition between pauperem and dives invite an interpretation on a metaphorical rather than literal level. Here the inverse of the usual petition for patronage is emphasized, with the "poor" poet being asked for favour by the wealthy. Richard Rutherford (2007: 253) comments: "Especially interesting are the ways in which [Horace] creates analogies between the way this antithesis works in literature and the way it figures in life: style mirrors lifestyle, and vice versa. Poets were traditionally poor."

132 Sat. 1.3.63-65.

133 Gowers (2012) 282.

134 Gowers' term (285). She notes that doctus was a "buzzword referring specifically to scholarly Alexandrian learning" but finds it "an unlikely claim here, given the pest's penchant for lowbrow art forms (II. 23-25)." For my take on this usage, see above. 
point reinforced by the pest's tortuous syntax at Sat. 1.9.25 when he claims that even Hermogenes would envy his singing: invideat quod et Hermogenes ego canto. ${ }^{135}$ Horace thus reinforces through this entertaining story the general point developed through the book, that those who aspire to be docti, and hence part of a literary elite capable of appreciating true quality in poetry, require genuine erudition and critical discrimination; simple enthusiasm and ambition is not enough. The last little touch to the poem underscores this point: it is Apollo, god of poetry, who rescues Horace from his awkward situation (Sat. 1.9.78).

In Satires 1.10, Horace then returns to a more learned discussion of poetry composition, in a poem that serves effectively as his poetic manifesto both for his work and for defining the audience he is seeking to reach. He begins by returning to his comments about the style of Lucilius that he had made in poem 4, but with the extra dimension of inviting his now primed readership to reflect on the validity of his commentary:

nempe incomposito dixi pede currere versus

Lucili. quis tam Lucili fautor inepte est

ut non hoc fateatur? (Sat. 1.10.1-3)

Certainly I said that Lucilius' lines ran haltingly and inelegantly. Who is so fanatical an admirer of Lucilius as not to admit such? (trans. Brown 1993)

He picks up this critique again later, in similarly engaging his audience in dialogue about the criteria by which poets should be assessed, returning to the comment about Lucilius that he had already made at Satires 1.4.11:

at dixi fluere hunc lutulentum, saepe ferentem plura quidem tollenda relinquendis. age, quaeso, tu nihil in magno doctus reprehendis Homero ? (Sat. 1.10.50-52)

135 This line echoes Sat. 1.3.129-30: ut, quamvis tacet, Hermogenes cantor tamen atque / optimus est modulator, where Horace is satirizing the Stoic doctrine that the wise man alone is potentially an expert in any area, even if he did not literally practise any. The text projects a dialogue between Horace's poetic persona and a Stoic who takes this argument to absurd lengths by asserting that Hermogenes, even if he didn't sing, would still be the best singer. 
But I said that he flowed like a muddy stream, often carrying more that should be removed than left alone. Come, tell me, do you with your expertise find no fault in the great Homer? (trans. Brown 1993)

Here Horace is inviting those who aspire to be $d_{o c t i}{ }^{136}$ to admit that the work of even the greatest of poets can contain infelicitous elements, and hence that literary appreciation depends on careful reading, not on uncritical admiration or condemnation. Thus, despite his earlier criticism, he is quick to concede Lucilius' good qualities; he entertained by the saltiness of his wit: sale multo urbem defricuit (Sat. 1.10.3-4), he was genial: comis et urbanus (1.10.65), and certainly more polished than his contemporaries: limatior idem / ... / quamque poetarum seniorum turba (1.10.6567). But Horace asserts (1.10.67-70) that that standard is now insufficient, and that had Lucilius lived in the current age (nostrum ... in aevum) he would have taken more care over his work.

In Satires 1.10 then, Horace lays out the poetic qualities the careful reader should look for, and which, by implication, he will be seeking to express through his own verse. These include brevity in construction to enable fluidity of thought (Sat. 1.10.9), together with modulation of style and tone so as to elicit different moods (1.10.11-14). He considers how far Roman poets should incorporate Greek elements, whether vocabulary, forms or themes (1.10.20-30), before concluding, through reference to his dream of Romulus (1.10.31-35) that they should generally give precedence to Latin forms. Finally, as already noted, he stresses the need for constant revision and emendation (1.10.72-73). He concludes the discussion by then defining the kind of erudite and discerning readership (docti) he is aiming at (1.10.81-88), as mentioned above, inviting all those alii who ascribe to these values to join the circle of his amici.

136 Brown (1993: 189) detects an ironical tone in doctus here in relation to the literary preferences, "perhaps suggesting Alexandrian sympathies" of the implicit addressee in this text, a view supported by Gowers (2012: 329). Yet Brown (193) finds no irony in the use of the epithet at Sat. 1.10.87: doctos quos et amicos / prudens praetereo, applying it especially here to "stylistic awareness." What Horace may be doing at 1.10 .52 is challenging those already erudite readers whom he wishes to draw into his audience to nevertheless retain an open mind about what constitutes poetic quality, to take neither Catullus nor Homer as absolute models. The reference to Homer's occasional shortcomings foreshadows the famous line from the Ars Poetica, 358: indignor quandoque bonus dormitat Homerus. 
In the final line he appends this poetic manifesto to his book of Satires as it is sent off for publication:

i, puer, atque meo citus haec subscribe libello (Sat. 1.10.92).

Go, lad, and quickly add these lines to my little book. (trans.

Fairclough 1961)

In summary, if we return to the question of author intention with which we began this chapter, this analysis allows the conclusion to be drawn that Horace's principal ambition in this first published work was to establish his credentials as a poet and to develop an audience that would be both sympathetic to him and sufficiently critically attuned to appreciate the subtleties of high-quality poetry. Viewed from this perspective, Satires 1 constitutes a preliminary discussion document about poetry, as befits its conversational form (sermo), rather than as a highly polished and innovative masterpiece such as was later to emerge with the Odes. But without thus first acquiring his audience, and then engaging them in thinking about what should constitute good poetry, any attempt by Horace at producing such may have been still-born. 


\section{Chapter 4}

\section{The Search for a Poetic Form}

In the previous chapter we discussed the manner by which Horace set out to construct a discerning and appreciative audience through the dialogic process embedded in his Satires. But this process left largely inchoate the "external intentions" the primary author Horace may have had for his poetry. What did he want to say to his audience through his verse, and what form would he adopt to express that communication? Was his intention primarily aesthetic in the prevailing Alexandrian mode - the creation of exquisitely crafted literary artefacts? Or did he essentially envisage a social and political role for his verse to speak prophetically to a turbulent age? Or some other aim?

Evidence about any early desire by Horace to address political themes is limited and must be treated with care. Many commentators put down his support for the Republicans prior to Philippi to youthful idealism, moderated, when he returned to Rome and became part of Maecenas' circle, to first a tacit, then an increasingly open support for the Augustan regime. ${ }^{137}$ Timothy Johnson's recent study, on the other hand, perceives responses in the work of both Horace and Propertius to the "hurt and guilt" occasioned by the civil wars: "It stands to reason that they would be concerned with giving voice through their poetry to the anger and pain of their people". ${ }^{138}$

But if so, such a concern is not apparent in either book of the Satires. Certainly the poet does mock certain social attitudes and practices, notably in the "diatribe satires" 1.1 to 1.3. But there the persons manifesting these are either unnamed, or are minor literary or artistic figures who it is safe to satirize. By the time Satires 2 emerged, Horace had moved away even from this limited social critique, with this book centred mainly on philosophical dialogue and in a setting of "after-dinner conversation." 139

\footnotetext{
137 See, e.g., Nisbet (2007) 8, Armstrong (2010) 26-27, Gowers (2012) 5ff. Muecke (2007) 115 states: "Satires 1 constructs a positive image of Maecenas, the young Caesar and the values they represent. This image $[. .$.$] is a calculated attempt to win over his readers to the new ruler."$

138 Johnson (2012) 3.

139 Muecke (2007) 118.
} 
On the other hand, evidence from the Epodes suggests that from early in his career, Horace was beginning to experiment with poetic forms other than the hexameter verse of satire. While it is problematic to assign secure dates to the composition of particular epodes, both Fraenkel ${ }^{140}$ and very recently Günther ${ }^{141}$ locate the writing of Epodes 7 and 16 as early as 38 BCE. Both these poems address the Roman political situation, with the poetic voice apostrophizing the citizens of Rome about the evils of civil strife. In the last two lines of Epode 16 especially, the poet claims a prophetic (vatic) function, urging his fellows to heed his warnings. Setting the current political turmoil within the myth of the progressive degradation of the ages of man, the poem concludes at Epod. 16.65-66:

$$
\begin{aligned}
& \text { aere, dehinc ferro duravit saecula, quorum } \\
& \text { piis secunda vate me datur fuga. }
\end{aligned}
$$

First with bronze, then with iron he (Jupiter) hardened the generations of men. A blessed escape is offered to their righteous members if they heed me as their seer. (trans. Rudd 2004).

The claim to such a prophetic role at this early point in Horace's career has provoked astonishment among some commentators. William Fitzgerald observes: "The arrogance of this [prophetic claim] is remarkable and extremely unusual in the self-deprecating Horace." ${ }^{142}$ Günther, however, takes a different view, asserting: "With a poem like Epode 16, Horace aspired at the very start of his career to a poetic voice that would enable him to treat more serious subjects than the nugae of Neoteric poetry", adding later "the aspiration to such a voice was the prime movens of Horace's turn to archaic Greek models in general". ${ }^{143}$

Horace's adoption of satire and the dactylic hexameter for his first published work may therefore not have been intended as his definitive choice of genre and form. As he relates in Satires 1.10, he chose satire initially because it was a genre not currently engaged in by any of his leading contemporaries, except for Varro of Atax, whose writing

\footnotetext{
140 Fraenkel (1957) 52.

141 Günther (2013) 169.

142 Fitzgerald (2009) 143.

143 Günther 176, 191.
} 
he was sure he could improve on. ${ }^{144}$ As we have seen, satire provided him with a dialogic vehicle for engaging with an audience, but it would not realize any ambition he had to be poetically innovative. Though he might smooth out the rough edges of Lucilian satire, he would always be, and be perceived as, inventore minor (Sat. 1.10.48). ${ }^{145}$

Günther surmises therefore ${ }^{146}$ that Horace may well have been experimenting with other metres even before 38 BCE. Under such a scenario, Epode 16 becomes a good candidate for a transitional form as it is composed in couplets consisting of a dactylic hexameter, as used for the Satires, followed by an iambic trimeter ${ }^{147}$. It was through iambic metres that Horace initially believed he could compose poetry that was aesthetically polished as well as being socially engaged. His two models for such verse were to be Callimachus on the one hand and Archilochus on the other.

In Epistles 1.19.23-25, Horace describes what he had derived from Archilochus:

Parios ego primus iambos

ostendi Latio, numeros animosque secutus Archilochi, non res et agentia verba Lycamben.

I was the first to show to Latium the iambics of Paros, following the rhythms and spirit of Archilochus, not the themes or the words that hound Lycambes. (trans. Fairclough 1961)

This assertion and the passage in which it is embedded (Epist. 1.19.21-34) have been exhaustively analysed by commentators. Alessandro Barchiesi's interpretation has it that Horace followed Archilochus in "metrical practice (numeros) and spirit or passions (animos), yet refused that poet's subject matter (res) and the language of personal

144 Sat. 1.10.46-47. Nothing is known of this Varro's satires, for which this is the only reference: Gowers (2012) 327. He is to be distinguished from the more famous M. Terentius Varro, author, among other works, of 150 books of "Menippean" satires in a mixture of prose and verse: Conte (1994) 215.

145 Quintilian however does not agree: "Lucilius has both remarkable learning and remarkable freedom. Horace is much more refined and pure; [...] he is the best of them all (praecipuus)". (Inst. Orat. 10.1.94).

146 Günther (2013) 170.

147 Llewelyn Morgan (2010) 177 sees in this poem a careful metrical construction where the distich juxtaposition of hexameter and iambic trimeter reflects the poem's contrast between "notions of stability and motion, fixity and flight, praise and condemnation" as being inherent generic markers of the two metres. 
invective and slander (agentia verba Lycamben)". ${ }^{148}$ We might also note Horace's claim to have been the first to introduce Parian (that is, Archilochean) iambic into Latin verse, whereas Hipponactean iambic, at least in the form of its metre, the choliambic scazon or "limping iambic", had already been used by Catullus and other Neoterics. ${ }^{149}$

How we should interpret Horace's adoption of "iambi" revolves therefore around how that term is to be defined within the context of ancient literature. This question has been thoroughly and lucidly discussed in a recent work by Andrea Rotstein (2010). She investigates whether, first for the Greeks, then for the Romans, iambos principally signified the metre or metres that were based on the iambic disyllabic foot (short plus long syllable), or on the other hand, whether iambos in the ancient context primarily refers to a register and tone of vituperative invective, occasionally combined with gross obscenity (aischrologia).

Firstly, it is generally recognized that in the ancient literary world, generic classification of poetry was basically determined by the metre employed. Thus epos referred to any long hexameter poem, elegeia to those composed in elegiac couplets, iambos to those in iambic measures. But because each of these metres tended to be reserved for particular poetic subjects or registers, the generic description came to include these aspects as well. Thus "epic" came to be associated with mythic or heroic narrative, "elegy" to poetry of lament, and "iambic" to lampoons or invective poetry. ${ }^{150}$ These in turn became associated with their prototypical practitioners. Thus, while Homer was the prototype for epic, Archilochus became perceived as the prototype for iambic-invective verse.

148 Barchiesi (2001) 143. Morgan (2010) 120 points to a parallel here with Callimachus, lambi 1.1-4, where that poet invites readers to "listen to Hipponax, for I come bearing iambic verses which do not sing the feud with Bupalos". Morgan elucidates this as meaning Hipponactean iambus without the persecution of Bupalos, "just as Horace would later claim to have composed Archilochean iambus 'without the themes and words that hounded Lycambes."'

149 Conte (1994) 808. Catullus however also composed in iambic trimeter, a metre definitely associated with Archilochus (Cat. 4, 29, 44 and 52). Horace's claim to primacy in transposing Archilochean iambic therefore remains disputable, at least on the purely metric level.

150 See Morgan (2010) 16 ff., who quotes Ovid's Remedia Amoris 371-386 for the list of subjects associated with the various genres. 
In attempting to unravel the skein of meaning bound up in the word iambos, Rotstein investigates ${ }^{151}$ how Aristotle in the Poetics variously employed this word and its related cognates. On the one hand, iambos is identified as a colloquial speech rhythm (rhythmos), which, says Aristotle ${ }^{152}$, was gradually fashioned into a poetic measure to imitate such speech (mimesis). But as poetry diverged between the imitation of "noble" and that of "mean" actions, each form found its own peculiar measure (metron), with the iambic speech rhythm providing the basis for the iambic metre used for composing satires (psogoi). But then Aristotle gives an etymological derivation for iambos by calling it the "lampooning measure, being that in which people lampooned one another." 153 However, his argument runs the risk of circularity in that it is unclear whether the primary meaning of the verb iambizô is "to lampoon or abuse", or whether it is "to write/speak in iambic metre" ${ }^{154}$ Although the etymology therefore remains uncertain, Rotstein finds ${ }^{155}$ that by the later fourth-century BCE at least, the term iambos had effectively become identified with the poetry of invective and abuse.

How far this was the received understanding of the term in $1^{\text {st }}$ century BCE Rome, however, is unclear. Catullus employs the word iambi four times in defamatory contexts - in poems 36.5, 40.1-2 and 54.6, and again in fragment 3 (Mynors). However, the three poems and the fragment are all composed in phalaecean hendecasyllables rather than iambic metre. Timothy Johnson consequently finds that this serves to corroborate the assumption that the term iambus is synonymous with verbal assault, regardless of the actual metre employed. ${ }^{156}$ But did this mean conversely that iambic metres could also be employed in contexts that were not vituperative?

\footnotetext{
151 Rotstein (2010) 61ff.

152 Poetics $1448^{\mathrm{b}} 20-32$.

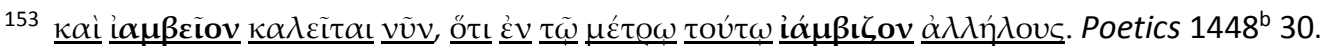

154 LSJ, s.v. $\underline{i} \alpha \mu \beta-i \zeta \omega$, A. assail in iambics, lampoon, II. abs. talk in iambic verse. The Aristotelian usage in the Poetics is one of three references given for the first meaning.

155 Rotstein (2010) 318.

156 Johnson (2010) 48. Cameron (1995) 165 makes the same observation, concluding: "If we take all four [Catullan usages] together, it seems impossible to doubt that Catullus counted phalaeceans as iambi." Horsfall (1981) 109 reiterates this dual perception of iambi, affirming the term denoted "as Horace and Quintilian both well knew, not only a metre but a genre."
} 
Horace's assertion in Epistles 1.19 that he adopted the metre and animus of Archilochus but not the subject matter and attack mode suggests that he, initially at least, entertained this possibility. If seeking another generic form to pursue his conversations (sermones) with his audience beyond the framework of the Satires, then iambic metre, with its rhythms attuned to natural speech, may well have appealed as a suitable choice. For Aristotle had also identified iambos as the most suitable measure for dramatic dialogue, whether for tragedy or comedy. ${ }^{157}$ This dramatic function for iambic is echoed by Horace in the Ars Poetica 79-82 where, in a section devoted to the functions of various metres, he declares:
Archilochum proprio rabies armavit iambo; hunc socci cepere pedem grandesque cothurni alternis aptum sermonibus et popularis vincentem strepitus et natum rebus agendis.

\begin{abstract}
Rage armed Archilochus with its special weapon; this foot was accepted by the comic plimsolls and the heavy tragic boots, suitable as it is to dialogue, more than a match for the racket of the crowd, and born for action. (trans. Morgan 2010: 145).
\end{abstract}

Horace had already juxtaposed Archilochus with Greek comic playwrights in Satires 2.3.11-12 when indicating what books he was taking to read out of town. ${ }^{158}$ Given the relative contemporaneity of the composition of Satires 2 with the Epodes, this, together with the retrospective commentary in the Ars, suggests that during the 30s Horace was turning to iambic (identified with Archilochus) as a means of engaging his audience in dialogue (alternis aptum sermonibus) through recognizably theatrical dialogic forms. lambic promised to provide him with an arresting register vigorous enough to be heard above the popular noise (popularis vincentem strepitus) by those with a finely-tuned ear, and capable of eliciting an active response (natum rebus agendis). ${ }^{159}$

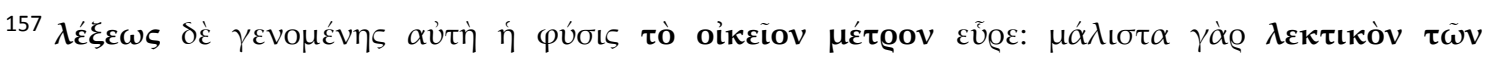

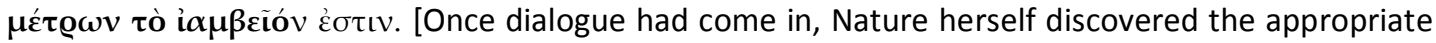
measure. For iambic is, of all measures, the most colloquial.] Aristotle, Poetics 1449a 23-26. Granted, Aristotle was referring to the natural speech rhythms of Greek, not Latin. But one might postulate that the dramatic and dialogic associations of iambic derived from Greek carried over into the Roman literary consciousness regardless of the actual speech-rhythm correspondences.

158 Along with Archilochus he took Eupolis representing Old Comedy, Plato (not the philosopher), for Middle Attic Comedy and Menander for New Comedy.

159 In this context, natum rebus agendis refers in the first instance to the appropriateness of iambic for carrying the play through, "getting the stage business done". But Morgan (2010) 145-46 notes that "the capacity to embody action (rebus agendis) rephrases Aristotle's observation that iambic trimeter
} 
Locating Horace's choice of iambic in a theatrical context, therefore, provides a framework within which to account for the invective poems in the Epodes. For contrary to the invective tradition, as most recently exemplified by Catullus, the targets of abuse in this book are either unnamed or appear under stage-names (Canidia, Epodes 5, 17; Mevius (probably), Epode 10). Dramatic dialogue is incorporated into several $(5,12,17)$. Thus, the reader is being invited not to read these particular poems as invective on the part of the poet himself (whether primary or secondary author) in the Archilochean manner, but as theatrical mime, and hence to respond to them as a theatre audience does to stage dialogues. ${ }^{160}$

Support for this proposition may be found in Elena Esposito's discussion of the "mimiambs" - mimes in iambic metre - of the Hellenistic poet Herodas ${ }^{161}$. She describes mimes as short compositions focusing on character portrayal and features of everyday life. Herodas's miniambs were characterized by their brevity, meticulous form and their renovation of traditional forms through "a painstaking recovery of archaic genres". 162 They included heterogeneous poetic elements which served to invert and subvert generic expectations. Hence, Esposito concludes, it required a highly cultivated audience to appreciate their sophisticated humour and allusions to the literary tradition. Now though there is no absolute corroborating evidence, it is reasonable to assume Horace was aware of Herodan mime, as of Theocritean, as these were known to be still in circulation in Rome up to the Imperial age. ${ }^{163}$ Such a form may have suggested an appropriate framework within which to integrate the revival of an archaic metrical prototype (Archilochean iambic) with the Alexandrian poetic aesthetic.

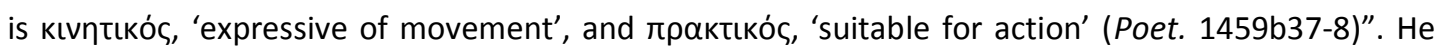
follows Barchiesi (2001) in seeing as the common factor in this description the attribution to the iambic foot of "a kind of innate energy" which is not limited to its application to theatre.

160 Horace's association with dramatic metres has been noted by Barchiesi (2001) 151 in relation to Epode 17 which he describes as a "dramatic' or at least 'mimic' iamb," saying: "In this poem [...] the metrical code is overshadowed by the scenic genre and reclaimed for its theatrical normality."

161 Esposito (2010), 267-281.

162 Esposito (2010) 268.

163 Esposito (2010) 278. 
In the light of this hypothesis, let us consider the programmatic structure of the Epodes collection that subsequently emerged. In the first instance, the book is, broadly speaking, organized metrically. The first ten poems are composed in the iambic strophe (iambic trimeter + dimeter). The remaining seven show a variety of metres, ${ }^{164}$ though all are partially iambic except for Epode $12 .{ }^{165}$ This organization has been linked by commentators to Callimachus' 17-poem book of lambi, although in that collection only the first four poems show the same metre (stichic choliambics). ${ }^{166}$ But there is much critical doubt about whether Callimachus so structured his book himself, as only the first 13 are iambic in metre, with the remaining four being lyric poems in other metres. However, Alan Cameron is convinced by papyrological evidence that Callimachus's poem 17 was the final poem "in a roll that otherwise consisted of the lambi"167 and refers to Horace's 17-poem book of Epodes as supporting evidence, implying thereby that Horace was familiar with a 17-poem lambi collection.

In summary, a reasonable conclusion to draw from this nexus of influences is that Horace sought to combine in his book of Epodes the iambic metre and vigour of Archilochus with the technical artistry and polish of Callimachus in order to create a poetic vehicle for engaging in dialogue with a learned and discerning audience and for prompting a response from that audience to the political, social and aesthetic questions that the book would address. Though he was plainly aware of iambic's association with virulent abuse, the model of Callimachus' lambi which the form of his book echoed offered the opportunity for the enrichment of the iambic genre to embrace other modes of discourse without losing its essential vigorous animus. ${ }^{168}$

\footnotetext{
164 Epodes 14 and 15 share the same epodic metre (dactylic hexameter + iambic dimeter).

165 Relating to which see my later comment.

166 Günther (2013) 172 notes: “Arrangement by metre was the Hellenistic method of compiling books of ancient poetry".

167 Cameron (1995) 169-70. For a contrary view see Ruth Scodel (2010) 258.

168 David Mankin (1995) 12, following Horsfall (1981) 109, asserts that lambi was also the designation Horace himself gave to the collection, citing its use in several poems, notably at Epodes 14.7 and Epist. 2.2.59. In passing, Mankin dismisses the idea that Horace's Iambi "owe anything to Callimachus". On the other hand, indirect support for the parallel with Callimachus' lambi may be found in a 2012 study by Acosta-Hughes and Stephens. They note that Callimachus' $1^{\text {st }}$ lambus "begins with the mimesis of Hipponax who "materializes specifically to chastise the squabbling critics of Alexandria" (57). Johnson (2012) 31 for his part certainly sees an imitation between "Horace's apologia for his iambic" and "Callimachus's qualified simulation of Hipponax". Cf. Harrison (2007a) on 'generic enrichment'.
} 
To what extent, then, does Horace realize this dual ambition within his book of Epodes? Is there any significance to be drawn from the way the collection is ordered? How far can a dialogic dimension that engages the audience be identified in this work?

Epode 1 functions as a programmatic introduction to the collection, even though its references to Actium suggest it may have be among the last to be composed. ${ }^{169}$ It announces the dominant metre (iambic strophe), evoking Archilochus, but at the same time posits a Callimachean framework for the form and content. ${ }^{170}$ It immediately engages an addressee, saluted at Epodes 1.2 as amice (not identified until 1.4 as Maecenas), in a dialogic relationship with the poetic persona. ${ }^{171}$ The addressee is informed that he will be led on a journey in a slender Liburnian galley in and out of a fleet of towering warships. This image is interpreted by Johnson as a metaphorical illustration of Horace's ambition in the Epodes to adapt Callimachean slenderness and techne, as propounded in the Aetia prologue, to the service of serious topics. ${ }^{172}$

The dialogic tenor of the poem is then reinforced in the form of rhetorical questions to Maecenas about how far the poet should get involved in the political affair alluded to, contrasting the otium of the disengaged poetic life (Epod. 1.7) with the labor of political engagement (1.9). The metapoetic dimension that the poet is inviting his audience to grapple with here, however, is how far a poetic form not traditionally associated with heroic narrative can or should be adapted to such purposes, an issue emphasized in the question at 1.15-16: roges tuum labore quid iuvem meo / imbellis et firmus parum? Here on the one hand the poet is aspiring to share in the labor of the addressee, but acknowledging that his character is imbellis et firmus parum. ${ }^{173}$ The answer given is:

169 Both Epodes 1 and 9 relate to the Actium campaign, with 9 clearly celebrating the victory whereas 1 in its content at least appears to precede the battle.

170 Johnson (2012) 82 sees it the other way round, with Epode 1 "investing Callimachean iambic with the Archilochean spirit".

171 Johnson (2012) 79 comments regarding Epode 1: "Horace teaches his audience immediately that iambic depends on the ego-tu relationship and the demands it places on those involved". Johnson sees a significant connection between the first word of the poem, ibis, and Callimachus' poem with this title, though not all commentators agree.

172 Johnson (2012) 80.

173 The metapoetic aspect of imbellis as a commentary on the lyric poet's domain as unsuitable for serious matters is echoed in Odes 1.6.10-12: imbellisque lyrae Musa potens vetat / laudes egregii Caesaris et 
comes minore sum futurus in metu - the poet will be less apprehensive with Maecenas, and through him, the discerning and supportive reader, at his side in his venture into perilous aesthetic waters.

In this way, Horace succinctly establishes at the outset of his collection the metrical, programmatic, dialogic and thematic parameters it will embrace. The remainder of Epode 1 then places a few more markers to generic identity and the potential enrichment of iambic that Horace intends for his book. The simile of the bird bravely but fruitlessly protecting her chicks (Epod. 1.19-22) has been linked ${ }^{174}$ to Archilochus' adaptation in frs. 174 and 175 of Aesop's fable of the fox and the eagle. This points ahead to the use of similar animal imagery in Epodes 4 and 6. The generic enrichment of iambic is extended in the final twelve lines of the poem to embrace Theocritan bucolic (Epod. 1.25-28), epic and historical themes through the reference to the "Circaean walls of lofty Tusculum" (1.29-40), and comic theatre, with the mention of the miser Chremes and the wastrel (1.33-34).

Four lines from the end, however, the poet reaffirms his interlocutor's kindness benignitas tua - which has provided him "enough and to spare" for his needs - satis superque - a phrase which will be echoed ironically at Epod. 17.19. The immediate referent for tua is of course Maecenas. But the context here does not indicate the nature of that bounty, and a reading that equates that benevolence to a discerning audience of amici docti may also be derived from it.

Epode 2 then embraces a bucolic theme, employing language and imagery that Horace will later echo in Odes 1.17. Lines 2.10-11: aut in reducta valle mugientium / prospectat errantis greges foreshadows C. 1.17.17-18: hic in reducta valle Caniculae / vitabis aestus, while the Epode 2 image of the wandering herds is echoed by the image of the wandering goats at $C$. 1.17.5-7. But the final two couplets of the poem (2.66-70) reveal

tuas / culpa deterere ingeni, and at Odes 1.15.15: imbelli cithara carmina divides, addressed to Paris who spends his time entertaining ladies in safety instead of fighting.

174 By Barchiesi (2001) 155 and Harrison (2007a) 111. 
that the bucolic delights, which have become more self-indulgent as the poem progresses (note the first person me introduced at Epod. 2.49), have been evoked by a money-lender named Alfius, who at that point suddenly realizes that it is time to call in his loans. This ironic and comic twist subverts the reader's initial generic impression and establishes the poem as mimic theatre, with the readers cast as its spectators.

Epode 3 is cast as a sympotic dramatic monologue, a form Horace will pick up again at Odes 1.27 and 1.29. It introduces a mock-epic element in the allusions to the myths of Medea and Deianaira, who caused the deaths of Glauce and Hercules respectively by smearing their garments with poison, in order hyperbolically to describe the effects of the garlic that Maecenas has served at dinner. The poem also includes an Archilochean curse element, but its effect would be only that Maecenas would be rebuffed at afterdinner sex $!^{175}$ The overall effect of the poem is to incorporate into iambic incidental aspects of traditional myth, much as the neoterics had done, but at the same time to subvert through humour the essential invective characteristic of iambic verse.

Viewed programmatically, the first three epodes project an intention to expand the generic boundaries of iambic to encompass a polyeideia such as Callimachus achieved in his lambi. Archilochean metre has been well established through the use in all three of the iambic strophe, while certain Archilochean motifs are also present, but with a softening of the archaic iambicist's vituperative tone.

Nevertheless, iambic's association with invective could not be entirely ignored, and Epode 4 may be interpreted as the poet's attempt to get his audience to face up to this issue and their prejudices about it. In this poem the poetic voice directs abusive scorn at an upstart who has the temerity to claim the prerogatives of an eques. While neither the target of the abuse nor its deliverer are identified, the initial impression is that it is Horace's voice we are hearing. But the sudden transition at Epod. 4.11 to echoing the vox populi may induce a realization that it is the poet's objective persona himself who is the object of attack, an impression reinforced in the final line's incredulous sneer: hoc,

\footnotetext{
${ }^{175}$ A point noted by Watson (2007) 100: "the exaggeration of the mythic comparisons (Medea, Hercules) turns [the curse] to bathos."
} 
hoc tribuno militum. ${ }^{176}$ We again have public theatre, but where the poet is challenging his audience to rethink their entrenched views by first seeming to reinforce them then abruptly turning them on their head.

The theatrical compass of iambic is fully embraced in Epode 5, where the audience is offered the frisson of observing the malevolent witch Canidia ruthlessly sacrificing an innocent boy to use his organs to make a love-charm. The whole structure of the poem is built around dramatic dialogue interspersed with narrative, but the scene ends before the final act is committed. Canidia clearly recalls the Medea of Epode 4 by allusion at Epod. 5.21-22 ${ }^{177}$ and directly at 5.61-62 ${ }^{178}$ while the boy hurls curses "worthy of Thyestes" at 5.86-102. In this poem the iambic association with tragedy that Horace later will allude to in the Ars Poetica is laid out.

Epodes 6-10 then form the heart of Horace's iambic project, linked together by a series of recurring lexical ties or images in the manner more extensively apparent in the Odes. In Epode 6 iambic's full invective power is laid plain in the sustained attack on a cowardly libeller in terms recalling Archilochus' use of animal imagery in such invective, and with explicit reference to both Archilochus and Hipponax as virulently hostile to their enemies. But again there is an ironic twist in the rhetorical question of the concluding strophe, Epod. 6.15-16: an si quis atro dente me petiverit / inultus ut flebo puer? This immediately recalls the puer of Epode 5, pursued by the dente livido of Canidia (Epod. 5.47), but the reference to weeping, even if intended ironically, seems to emasculate the threat, particularly since the supposed offence remains vague. This apparently feeble end has perplexed commentators, who have proposed various ways to account for it. ${ }^{179}$ But it makes sense if we see it as part of Horace's ongoing attempt in the Epodes to draw the invective teeth from iambic by its hyperbolic application in this poem to a situation where there is little or no justification for it.

\footnotetext{
176 An interpretation also made by Fitzgerald (2009) 151 and, slightly obliquely, by Johnson (2012) 99.

177 quas lolcos atque Hiberia / mittit venenorum ferax

178 cura dira barbarae minus / venena Medeae valent.

179 See for example Günther's convoluted explanation: (2013) 185-187.
} 
Following that interpretation, Epode 7 then presents the manner in which the animus of iambic may be applied within a political context, but with the aim of calling those targeted to account rather than casting anathema on them. The poem is linked back to Epode 6 by the verbal echo at Epod. 7.19-20: ut immerentis fluxit in terram Remi /sacer nepotibus cruor, of Epod. 6.1: quid immerentis hospites vexas canis, (where the participle immerentis, though of different grammatical function in each case, occupies the same sedes in the respective lines), and by the common use of animal imagery: dogs, wolves and bulls in Epode 6, dogs and lions in Epode 7. But the application of the Archilochean imagery and invective elements reveals a subtle shift operating from poems 5 and 6 to poem 7. In poem 6, the animals are metonymical projections of the characters of the adversaries: the libeller is a cowardly cur who shrinks from taking on more powerful opponents, seen as wolves, while the poetic persona casts himself as a faithful mastiff protective of the weak, or as a bull ready to toss villains who challenge him. In Epode 7, on the other hand, animals are held up as virtuous creatures who do not attack their own kind, in contrast to humans. Archilochean animal savagery is thus being softened. Finally, the iambic curse element, so prominently projected at the end of Epode 5, is in Epode 7 transposed to a warning to the Roman audience being addressed of the consequences for their descendants if they do not amend their impiety, rather than being a direct imprecation.

Horace is thus attempting here to transmute the invective element of iambic to vatic prophecy. But there are two audiences involved in this poem. For in fact, what we have here is another piece of theatre. Epod. 7.1-14 dramatizes the scene of a soothsayer virulently rebuking a Roman crowd (the diegetic audience) for its evil excesses (scelus) and demanding a response from them to the charges: responsum date! (7.14). But at 7.15 the poetic voice intervenes, shifting from theatrical denunciation to extra-theatrical narrative: tacent, before then passing into dispassionate commentary at 7.17: sic est: acerba fata Romanos agunt, where a second audience is engaged, cast first as theatregoers to whom the outcome of the scene is narrated, and then as readers who are invited to reflect themselves on the message of the "play." 
Viewed this way, Epode 7 can be seen as complementary to, rather than in stark contrast to, Epode 9, which celebrates Octavian's victory at Actium. The latter consists of an outer framing device - an invitation to and preparations for a celebratory symposium constructed by Epod. 9.1-10 and 9.33-38, where the voice is that of Horace's poetic persona. But in the central segment of the poem (9.11-32) the prophetic voice of Epode 7 re-emerges, on the one hand lamenting that a Roman (Antony) could have become enslaved to a foreign woman (9.11-12), but on the other ritually celebrating (io Triumphe: 9.21 and 21) the restoration of moral order through the virtue of another Roman - Caesar. And whereas in Epod. 7.17 it is the whole community of Romans (Romanos) who are held up to blame, at Epod. 9.11 it is a single Roman (Romanus) who personifies that guilt and with whose destruction Rome might return to piety. The implicit audience of invitees to the celebratory symposium, for whom Maecenas is the symbolic addressee, are thus once again urged to draw appropriate conclusions from the dramatic enactment at the heart of the poem.

In many ways, Epode 9 stands at the apogee of Horace's iambic experiment. It is the central poem of the 17-epode collection, and the one in which he finally applies iambic to the purposes of political commentary. The vatic voice is balanced between blame and celebration - the two contrasting aspects of Archilochean iambic, and the invective animus has been redirected in controlled and responsible fashion against an opponent who indeed has threatened the very stability of the state. Furthermore, Horace is here claiming success in addressing through a form of lyric metre serious matters traditionally reserved to epic or didactic hexameter: sonante mixtum tibiis carmen lyra (Epod. 9.5)..$^{180}$

However, just preceding Epode 9 is Epode 8, the first of two poems (with Epode 12) describing the sexual humiliation of the poet before the demands of an ugly older woman. The use in both of obscene invective certainly reflects the aischrologia of Archilochean iambic, but their inclusion in the middle of the epodic collection suggests

180 These are the same instruments that Horace will claim for his lyric in Odes 1.1.32-34: si neque tibias / Euterpe cohibet, nec Polyhymnia / Lesboum refugit tendere barbiton. Johnson (2012) 134 makes a similar point, when discussing Epode 9: "This is the first example in the Horatian corpus of a political theme in a sympotic context - a primary construct of his lyric". 
there is equally a metapoetic function at play here. Johnson observes that by imitating the full-blown viciousness of Archilochus's invective but without identifying the attacker or the attacked, Horace "calls into question the value of that iambic attack" ${ }^{181}$ and challenges his audience "to perceive an iambic operating beyond their stereotypes." 182 The clue to this interpretation is to be found in the echo in Epod. 8.3: dens ater, of Epod. 6.15: atro dente, which we have already also linked back to the dente livido of Canidia at Epod. 5.47. The hag of Epode 8 is thus associated with Canidia as the personification of iambic invective, demanding that the poet do more to satisfy her expectations. In this way, the poem implies that Horatian iambic is perceived as too mild. But the gross physical description of the woman suggests that this form of iambic is now thoroughly unattractive and unable to elicit valid performance from the poet anymore without the application of a different technique.

By Epode 12, however, the poet is being forced to concede that this attempt to change the character of iambic has been unavailing. His impotence, reflected in his exasperated opening question: quid tibi vis, mulier ... ? (12.1) reflects his inability to satisfy iambic's generic demands. He reports the woman sending him presents and tabellas (12. 2) love-letters, but also tablets for writing poetry on - but to one who is not a "hard young man" (firmo iuveni: 12.3), recalling the poet's self-description at Epod. 1.15 of also being firmus parum. But at line 7, what appeared to be direct dialogue is revealed as being reported by a narrating voice to an audience, as are the woman's later accusations. Thus again we have a mime, interspersed with commentary, engaging the audience in reflection on the use of iambic and its public reception. The poet reports the woman berating him for his distaste for cruel words: mea cum saevis agitat fastidia verbis: Epod. 12.13, and his failure to live up to the expectations of invective performance derived from Catullus: pereat male quae te / Lesbia quaerenti taurum monstravit inertem: 12.1617. Her ultimate charge picks up the Archilochean animal imagery to accuse him of shrinking from fulfilling the expectations of the genre: o ego non felix, quam tu fugis ut pavet acris / agna lupos capreaeque leones (12.25-26). Perhaps the final indignity to her expectations is that Epode 12 is no longer in iambic metre, but in the Alcmanic strophe,

181 Johnson (2012) 123.

182 Johnson (2012) 127. 
consisting of a dactylic hexameter plus dactylic tetrameter, thus very close to an elegiac couplet.

The remaining poems of the collection move away from pure iambic metres, apart from the last. While some commentators ${ }^{183}$ see in these poems a transition towards the Odes, they also note in them Horace's ongoing attempt to broaden the Archilochean animus to "accommodate topics that overlapped with those of lyric poetry." ${ }^{184}$ Despite these attempts at generic enrichment, however, Epode 14 shows the poet struggling to bring his iambic experiment to fruition. Within the poem he is asked by Maecenas (rogando: Epod. 14.5, echoing Epod. 1.15: roges), why he is having trouble completing the promised book: inceptos olim, promissum carmen, iambos / ad umbilicum adducere: Epod. 14.7-8. While the surface-level reason is his love for the freedwoman Phryne, the first two words of the poem: mollis inertia suggest other, metapoetic reasons. Mollis echoes the non mollis viros of Epod. 1.10 whose warlike labor he aspires to share but fears ill-equipped to do, and also evokes Epod. 12.16-17, where the poet is mocked by the woman as too mollis to complete even one opus and is revealed as inertem.

But we also find in Epode 14 the first clear indication of where Horace's poetic project is now heading in the reference to Anacreon at 14.10, the first mention of a canonical Greek lyrikos in his verse. While the god he says is keeping him from his iambic task at 14.6 is interpreted as being Amor, ${ }^{185}$ it can just as plausibly be taken to be Apollo, the god of poetry. It is Phryne, the new lyric mistress equally not satisfied with one man (14.15), who is now "keeping him on the boil". ${ }^{186}$

The collection concludes with two metapoetic pieces. Epode 16, discussed earlier, is slotted into the penultimate position, in part perhaps to reassert an ongoing commitment by Horace to a public, prophetic role for his verse, despite the imminent

\footnotetext{
183 See, e.g., Watson (2005) 94, Günther (2013) 194.

184 Günther (2013) 195.

185 Harrison (2007a) 125 makes this interpretation, seeing this as in indication of Horace's turning towards erotic poetry.

186 Davis (1991) 72 states that in Epode 14 "the poet surrenders to a more compelling Muse of a radically different persuasion".
} 
discarding of iambic as a vehicle for this. In this sense, the second half of the poem functions as a propempticon for his own poetry, signalling his departure with the melior pars (Epod. 16.15) of his art for more fruitful shores. Poem 17 then signals the closure of the iambic collection, but on a dual level. On the first of these, the poet concedes that Canidia, the personification of the invective spirit of iambic, has won out over his attempts to change its public image:

iam iam efficaci do manus scientiae

[...]

Canidia, parce vocibus sacris, citumque retro, solve, solve turbinem.

Epod. 17.1, 6-7

All right, all right! I yield to the power of your magic [...]. Canidia, I beg you, let the swift wheel you have set in motion run back, back. (trans. Rudd 2004).

Then, ironically echoing the superabundance - satis superque - of Maecenas' benignitas as his emblematic first reader at Epod. 1.31, the poet appeals to Canidia to recognize that he has been punished enough: dedi satis superque poenarum tibi: Epod. 17.19. But Canidia remains obdurate, declaring that her carmina, her destructive invective poetry, will remain unaltered by any attempt to soften it. She concludes by mockingly asking the poet: plorem artis in te nil agentis exitus: 17.81 - "so am I supposed to lament the failure of my art to have any effect on you?"187 But on the level of the aesthetic discernment of poetic composition, Horace may still have made his point. The last poem is the only one composed in "pure" stichic iambic trimeter, a metre used by Archilochus in his Lycambes invective, but also closely paralleling Callimachus' usage in his first four lambi. While the functional dimension of the iambic project may not have succeeded, the last poem still makes the strong statement that the pursuit of formal excellence following Callimachean principles was very much alive.

Furthermore, the order in which the poems have been arranged in the Epodes, which engages readers in a progressive exploration of the dimensions of the iambic genre

187 As various commentators have noted, the final word exitus marks the exit from the epodic project initiated by the ibis of 1.1, while I suggest that agentis foreshadows the agentia verba Lycamben of Epist. 1.19.25 and the rebus agendis of Ars 82 . 
before bringing them to a recognition of its limitations, reinforces the importance of the whole poetry book as the fundamental opus of the poet. The stimulus to reading the book in this holistic and interactive fashion is sharpened by the perception already in the Epodes of patterns of recurrent lexis and imagery that tie individual poems into the whole. This effect will become even more prominent in the Odes. 


\section{Chapter 5}

\section{The Construction of a Lyric Opus}

As we discussed in Chapter 4, by the time the Epodes collection was published around $30 \mathrm{BCE}$, it seemed that Horace was already looking for an alternative formal and metrical platform to iambic which could still permit the composition of both publically-engaged and aesthetically refined poetry but also be free from the burden of any particular generic expectation. The Odes would show that the platform he finally settled on was that of lyric verse, modelled upon the forms, genres and metres of the nine canonical practitioners of archaic Greek lyric. ${ }^{188}$ While Epode 14 suggests that his initial lyrical inspiration may have been derived from Anacreon, it was in particular to Sappho and Alcaeus that Horace turned for the metres and themes that he was to employ in the Odes. One advantage in taking archaic lyric as a model was that it had encompassed a broad range of human experience, both public and private, serious and convivial. And while Denis Feeney notes that the public political dimension had been displaced from personal poetry during the Hellenistic period, reviving archaic Greek lyric offered Horace a way of recapturing it and of finding a fresh and astonishing poetic voice. ${ }^{189}$

But archaic Greek lyric was far from a clearly defined poetic form. The Greek term lyrikós, meaning 'relating to the lyre', was first used by Alexandrian scholars cataloguing works of past poets who mentioned the lyre as accompanying the performance of their works. These they themselves tended to label as 'song' (mélos), which distinguished them from iambic or trochaic compositions which were spoken or recited. 190

\footnotetext{
188 In rough chronological order from the mid- $7^{\text {th }}$ to the mid-5 $5^{\text {th }}$ centuries these were: Alcman, Sappho, Alcaeus, Anacreon, Stesichorus, Ibycus, Simonides, Bacchylides and Pindar. Their canonical status was set principally by the Alexandrian scholars Aristophanes of Byzantium and Aristarchus, and they were so recognized in $1^{\text {st }}$ century BCE Rome. See Barbantani (2009) 302.

189 Feeney (1993) 45.

190 Budelmann (2009) 4, 12. Budelmann observes that "lyrikós seems to have been associated [by the Alexandrian scholars] in particular with early lyric poetry rather than contemporary work [and] is standard in lists of the canonical lyric poets".
} 
Definitions of archaic Greek lyric from a functional and content point of view have been proposed by various commentators. ${ }^{191}$ From these the following elements may be distilled:

(1) Lyric poems were generally short pieces composed for performance at a specific public occasion (e.g. a religious festival) or a private one (e.g. a symposium). They were sung by an individual singer, often the original poet, at a private event (monody), or by a choir at a public one (choral song). Monodic performance was typically accompanied by a lyre, played by the performer; choral performance by a wind instrument (aulos) played by a musician. ${ }^{192}$

(2) Lyric poems have a strong first-person narrative voice "anchored in the present,"193 directed to either an individual (named) addressee, or a collective (named or implicit) one. The communicative environment is dialogic, with the poetic voice addressing or interrogating the audience in a variety of tones, though poems rarely include interlocutory response.

(3) Lyric poems are grounded in a moment of time or space, from which other temporal or spatial perspectives are constructed: youth and age, mortality, seasonal cycles, departure and return, flight and exile.

(4) Lyric themes include love, friendship and group celebration. Love and its effects are commented on rather than narrated, and are generally presented decorously without coarseness or obscenity. Celebrations frequently include invitations to drink in moderation, along with warnings about excess.

(5) Lyric poems may be marked by overt self-reflexivity, ${ }^{194}$ making the occasion of the performance a theme as well as a context.

In the archaic period, lyric song (mélos) was performed as single compositions for a specific event. This however clearly allowed for re-performance, perhaps with minor modification, at subsequent events, and for popular or successful ones to be eventually

\footnotetext{
191 Among the more recent are Lowrie (1997), Barchiesi (2007), Budelmann (2009) and Carey (2009).

192 A large "concert lyre" might also accompany the singing and dancing of choral lyric, as indicated by Pindar in the first Pythian Ode.

193 Budelmann (2009) 7.

194 See Carey (2009) 34.
} 
written down. As a result, lyric works gradually changed in nature from spontaneous or memorized works for singing to written texts for reading.

By the Alexandrian period, scholars began compiling archaic song-texts into books in order to preserve a literary heritage that was already obsolete in its original melic form. The texts were arranged under various loose generic categories grouped in two divisions associated with their original performative contexts: ${ }^{195}$

(1) songs for the gods: dithyramb, paean, threnody (lament), hypôrchêmata (light dances), partheneia (maiden songs), prosodia (processionals) and hymns.

(2) songs for humans: epinikia (victory odes), enkômia (songs of praise), epithalamia (wedding songs) and thrênoi (dirges).

But there was also a large amount of lyric poetry that was intended for private or semiprivate entertainment. ${ }^{196}$ In the archaic period, the most significant setting for the latter was the symposion, ${ }^{197}$ where the most common types of songs were drinking songs (skolia) or erotic songs, but which could also include songs on serious civic or political themes. ${ }^{198}$ Contrary to most other ancient genres, however, lyric was not defined by metre. Yet metrical form was critically important, as the metres chosen had originally to lend themselves to singing. This led to a considerable range of metres being chosen, with the patterns for choral lyric being particularly complex. ${ }^{199}$

It is generally accepted, however, that in transposing the Greek lyric metres to Latin, Horace did not intend them to be sung. ${ }^{200}$ Nevertheless, when choosing metres suitable for mediating a first-person poetic voice, it would have been more natural to select those used in monodic rather than choral lyric. Of the nine lyrikoi, the three principal exponents of monodic lyric had been Sappho, Alcaeus and Anacreon. But Anacreon

\footnotetext{
195 Carey (2009) 21ff.

196 Carey (2009) 32.

197 This was a gathering for the purposes of drinking and convivial entertainment which ranged from informal celebrations to formal banquets. See Carey (2009) $33 \mathrm{ff}$.

198 Hobden (2013) 8, describes the dynamics of the archaic symposion thus: "Conversations through song make the symposion politically and socially involved. [...] Symposiasts oriented themselves in relation to past and present, to the world outside and the community within".

199 David Campbell (1988: II) 261-62.

200 This view was contested by Bonavia-Hunt (1969), but with little support from other commentators.
} 
composed mainly in iambic dimeter, which may not have provided the distinct break from iambics that Horace was seeking. That therefore left the Aeolic metres of Sappho and Alcaeus which became the principal metres used in the Odes, and which Horace claimed he was the first to introduce to Latin verse. ${ }^{201}$

While some odes may have been composed in the $30 \mathrm{~s} \mathrm{BCE},{ }^{202}$ Horace's greatest period of lyric creativity occurred between 31 (after Actium) and around 25. While it is probable that many of the poems that eventually made up the collection may have circulated among his literary friends during that time, public dissemination of these was delayed until mid-23 BCE, the almost certain date of the simultaneous publication of Odes 1-3. Such a delay suggests that the poet therefore intended that his lyric poetry should be read as a single work, and, given the format of publication in papyrus book-rolls, that the constituent poems should be read in a particular order.

But if so, it is worth considering what fundamental principle did Horace apply in determining the overall structure of the books and the order of the individual poems within them. There is sufficient evidence to show that they are not ordered chronologically, nor are they generally arranged according to metre after the fashion of Alexandrian poetry books. ${ }^{203}$ Nor broadly speaking is there any organization by theme or genre, though again with minor exceptions. As a result, the only ordering principle that has attracted any consensus is that of variatio, ${ }^{204}$ the variation from poem to poem of metre, length, genre, theme, tone and "atmosphere" 205 to enable the work to remain fresh and stimulating as it is read sequentially.

A second intriguing question relates to the continuing topicality by the time of their eventual publication of certain apparently early poems relating to the troubled period of the civil wars, at a time (23 BCE) when the Augustan settlement had effectively been

\footnotetext{
201 C. 3.30.13-14: princeps Aeolium carmen ad Italos / deduxisse modos. As with other such claims by Horace, this is not strictly true as Catullus had already used Sapphics in Cat. 11 and 51, the latter a near-translation of Sappho fr. 31.

202 See Günther (2013) 211ff. for a discussion of the potentially early odes.

203 Though there are some exceptions in Books 2 and 3, as will be observed.

204 See Nisbet \& Hubbard (1970) xxiiiff., Günther (2013) 219.

205 For a definition and discussion of this concept, see Collinge (1961) 46ff.
} 
consolidated. Why particularly give prominence, in the "Roman Odes", to the impious character of the Roman people some five years after Augustus had bedded in his religious and moral reforms? Such could be expected of a post mortem collection of earlier unpublished work, but less of a still engaged poet wishing to comment on the contemporary state of the Roman body politic.

Finally, to what extent may Horace have edited and revised his poems when preparing them for final publication ${ }^{206}$ While Nisbet and Rudd are sceptical, because of the "complex structures of the Odes"207, Günther asserts that in order to achieve the polish that is evident in the collection, Horace must have undertaken continuous revision, as well as giving careful thought to the arrangement of the poems in each book. ${ }^{208}$

In the light of these issues, it is my contention that, in the publication of his three-volume lyric opus, Horace presented it as a single, unified poetic creation, wherein each poem was individually autonomous but also integrated into the whole through patterns of lexical and thematic linkages between them. In doing so, the guiding principles that most closely reflect his practice are those of Callimachus as set out in the prologue to that poet's Aetia. ${ }^{209}$

If we might hazard an anachronistic analogy, we may from this perspective compare the Odes 1-3 tribiblos to a concerto in three movements, each of which has its own development, pace and rhythm, but where recurring formal, thematic and tonal leitmotivs bind the individual parts into a unified whole. Furthermore, given that the whole work thus transcends the time and place of its initial publication, it can be

206 A question which is certainly germane to the interpretation of the observed patterns of recurrent lexis in the Odes.

207 Nisbet \& Rudd (2004) xx. Barchiesi (2007) 149, takes the opposite view, stating "the assertion that design cannot have affected the texts of the individual poems once they had been fixed in writing [...] because of the complexity of the lyric metres I...] is to over-estimate the complexity of Aeolic rhythms".

208 Günther (2013) 217. Rossi (2009) 359 agrees, stating: "The Odes [...] appear to have been edited by the author himself with great care and attention given to the order of the poems".

209 Viewed this way, Odes 1-3 becomes a single long work, rather than a collection of short works. AcostaHughes and Stephens (2002) 242, argue that Callimachus does not oppose single long works as such, but that they should be told in "small increments" and through a Muse that has been made "slender". They note that such a principle "accurately describes the contents of the Aetia". 
experienced afresh as re-performance with every new reading undertaken, just as we re-receive a musical work each time it is performed anew.

For the remainder of this chapter, therefore, I wish to expound one such reading of the Odes 1-3 opus which demonstrates both Horace's commitment to keeping the highest standards of the Alexandrian aesthetic at the same time as providing a superbly functional literary vehicle to engage a receptive and astute audience in dialogue about both poetic artistry and the fundamental issues of personal, social and political life. But given the unfamiliar form, for his initial audience, of his chosen poetic vehicle on the one hand, and the prevailing generic prejudices, in the Gadamerian sense, of that audience regarding the appropriateness of certain poetic forms for particular functions, the challenge faced by the poet was to lead his readers by incremental stages through the process of reception until they might come to accept and appreciate the full dimensions of his achievement. But given that no lyric opus of this dimension had been realised before in Latin letters, this undertaking was "fraught with peril" ${ }^{210}$ both for his reputation as a poet and for the survival of his work.

Viewed from this perspective, Book 1 fulfils the function of introducing and developing Horace's method. It is the most metrically diverse of the three Books and covers the broadest thematic and generic range. The very first poem, $C .1 .1$, lays out the poet's ambition to be recognized as a lyric bard, vates lyricus (1.1.35), whose voice would speak in Aeolic measures through both private monodic lyric, symbolized by the Lesbian lyre (barbiton, 1.1.36), as through public choral lyric, represented by the pipe (tibia, 1.1.34). ${ }^{211}$ As is frequently observed, the Lesser Asclepiad metre employed is used again only in C. 3.30, the last poem of the collection, which creates an enclosing framework for the whole opus.

\footnotetext{
210 Feeney (1993) 45.

211 Lowrie (2009) 341 notes the similar linkage between the two instruments made at C. 1.12.1-2: quem virum aut heroa lyra vel acri / tibia sumis celebrare, Clio? which "recalls the programmatic fusion of monody and choral lyric at $C$. 1.1.".
} 
After the initial, brief dedication to Maecenas, the poem adopts the form of a priamel ${ }^{212}$ listing others' preferred pursuits before affirming the author's choice of the poetic career. However, while the priamel traditionally projected a disclaimer to interest in any activity except for the final one, a more careful reading of this list may see it rather as a praeteritio, which was a rhetorical device to draw attention en passant to a theme or mode while outwardly professing not to address it. Viewed this way, Horace is effectively giving prior notice of the themes he will consider appropriate for inclusion in lyric. The image of the Olympic victor $(C .1 .1 .3-6)$ is a nod of acknowledgement towards Pindar, considered the greatest of the Greek lyrikoi, while the dangers of sea-voyaging (C. 1.1.13-18) is a common theme of Alcaeus. The political and military spheres are evoked through the image of the consular candidate seeking votes (1.1.7-8) or in the sounds of camp life and warfare, symbolized by the bugles and trumpets (1.1.23-25). The central image in this list, however, is that of the otium of the idle drinker stretched out under an arbutus, recalling the self-portrait of the poet at the start of the Epodes. By contrasting the active lives of the others mentioned with the idler's passivity, the opening poem poses again the question of what is the appropriate social role for the poet.

While the first two thirds of the poem therefore invite consideration of what themes lyric may extend to, the final third projects the confident assertion of the poet's claim to be recognized as an Italian bard equal to the Greeks in the lyrical firmament. Apart from the first-mentioned Olympic victor, all the other actors are Italian, and it is only when Horace addresses the aesthetic domain that he anchors his poetry within a Greek environment (C. 1.1.30-34). ${ }^{213}$ By juxtaposing the Latin vates with the Greek loan-word lyricus, Horace "expresses the fusion of Greek and Roman poetry to which he aspires". ${ }^{214}$ The claim to a vatic role echoes that made in Epode 16, but with the difference now being that the poet seeks to exercise this role through lyric verse, and no longer through iambic invective.

\footnotetext{
212 Nisbet \& Hubbard (1970) 3, West (1995) 5, Günther (2013) 227.

213 Nisbet \& Hubbard (1970) 3.

214 Günther (2013) 231.
} 
Furthermore, whereas the brash young poet of the Epodes boldly asserted this role, the more mature poetic voice of the Odes projects a conditional mode. His position in the poetic pantheon will be assured if his claim to be a lyric poet is recognized: quodsi me lyricis vatibus inseres (C. 1.1.35). Yet who is it who will accord this recognition? The second-person singular form of the verb indicates Maecenas, the poem's addressee, in the first instance. But, given the programmatic function of this poem as the preface to Horace's whole lyric opus, it is not unreasonable to interpret the implicit tu of inseres as embracing as much the erudite audience the poet has been cultivating since the Satires as Maecenas himself as the emblematic first reader. ${ }^{215}$ But the future tense of the verb indicates that Horace is not claiming this status ab initio as he did in the Epodes. Instead, readers are invited to suspend their judgment until they have read the whole work. ${ }^{216}$

But the use of the present tense at C.1.1.29-30: me doctarum hederae praemia frontium / dis miscent superis, reveals that Horace is already claiming the ivy crown of the poetae docti, which the Satires showed encompassed those poets who had embraced the Alexandrian ethos of highly polished, slender works. Odes 1.1 acts thus as an identity statement for the whole of Horace's lyric project, where he lays out his credentials and invites his readers to accompany him on his poetic journey through the following 87 poems.

The first nine odes of Book 1 are all in different metres, and it has generally been assumed that Horace is here "parading" the range he will use in his work. Yet two of these metres, at $C .1 .4$ and 1.8 , do not recur at all throughout the whole opus, while that of 1.7 occurs again only at 1.28 . Furthermore, none of these three are Aeolic measures. On the other hand, a tenth separate metre is introduced at $C .1 .11$, after 1.10 repeats the Sapphic stanza of 1.2 .

${ }^{215}$ Regarding the identity of addressees in the Odes, Gregson Davis (1991), 6, comments: "the addressee [...] is most usefully regarded, in the first instance, as providing a context for lyric utterance. It is part of the necessary fiction of this dyadic mode that the poet "sings" to a "hearer". The proper name [...] ipso facto, selects and complements an amicus, while effectively serving to define that person as a worthy member of a lyric audience".

216 A point made by Nisbet \& Hubbard (1970) 15. "The future is better than the variant inseris: [...] here [Horace] pretends that Maecenas still has to read the collection." 
The choice of nine distinct poetic forms has also been associated with the nine poets of the Greek lyric canon. But apart from C. 1.2 in Sapphics and 1.9 in the Alcaic stanza, none of the others uses a metre distinctly linked to the other seven lyrikoi, nor do they allude to known works of these through intertextual mottos, except again for $C$. 1.9 where there is a clear allusion to an Alcaean text (fr. 338). This relative absence of definite linkage has led more recent critics to look for other structural features within this group. Günther, setting $C$. 1.1 apart as the proem to the collection, sees the next eight poems as "parading" the four major themes that the poet will develop throughout this work: politics; friendship and travel/absence; nature and enjoyment of life in the face of death; love. ${ }^{217}$ But there is perhaps more present here than a simple thematic overview. At least five of the Parade Odes, C. 1.2, 1.3, 1.4, 1.7 and 1.9 incorporate within a single poem elements of different lyric genres that abruptly shift from one to another, leaving some commentators puzzled about each poem's unity. ${ }^{218}$ What we may detect here is a challenge by Horace to the generic expectations of his audience, inviting them to find through this process of generic contrast and juxtaposition new associations between otherwise apparently disparate thematic elements. He is introducing demanding poetry, to which he wants his readers to be alert.

But the Parade also sets out the aesthetic parameters for the Odes collection. Readers are alerted to the poet's commitment to Callimachean technical artistry and poetic ethos in C. 1.5 and 1.6. The former, the "Pyrrha Ode", is an exquisitely crafted erotic epigram ${ }^{219}$ whose technical perfection is evident in its dazzling chiasmic interplay of lexis, syntax and imagery, especially in the first and last stanzas. In the latter, the placement of the nouns and their related epithets creates a verbal and mental picture of ex-votos on the wall of a shrine which recalls the ecphrasis technique of Alexandrian tradition.

\footnotetext{
217 Günther (2013) 216.

218 For example, $C$. 1.7 consists of (i) a priamel abjuring panegyric but culminating in an encomiastic eulogy of Tibur (1.7.1-14) (ii) a paraenesis (counselling epigram) directed to Plancus, the poem's addressee (1.7.15-21) (iii) a snippet of mythic narrative relating Teucer's imminent departure to found a new city in Cyprus, but culminating in an invitation to a symposium (1.7.21-32). "This [apparent lack of unity] puzzles moderns" say Nisbet \& Hubbard (1970) 93, "who expect a lyric poem to deal with a single subject".

219 Rated by Nisbet \& Hubbard (1970) 73 as "structurally flawless".
} 
C. 1.6 takes the form of a recusatio, or polite refusal by the poet to undertake an encomium of Augustus' leading general Agrippa because of an asserted lack of skill in composing in the epic mode. In doing so, however, Horace is echoing Callimachus in the Aetia prologue who equally requests not to be asked for a "song loudly resounding" (mega psopheousan aiodên), declaring that Apollo had urged him to "keep his Muse slender (tên Mousan leptaleên). Horace echoes this injunction at C. 1.6 .10 where his "unwarlike" (imbellis) Muse forbids him to venture on grand topics (grandia) because his verse is slender (tenuis). But the juxtaposition of these two three-syllable words forming the middle six of the dodecasyllabic Asclepiad line: conamur, tenues grandia, dum pudor, brings them into intense focus, both contrasting their senses and associating them. Thus, Horace is inviting his more perceptive readers to question this apparent "disavowal", as Davis prefers to call the recusatio. "Disavowal more readily suggests an act of verbal protestation without regard to the issue of underlying sincerity". ${ }^{220}$ Davis thereby detects a "paradoxical intent" in this poem, which disavows composing in epic form, but does not rule out addressing epic or serious themes. ${ }^{221}$

However the Parade Odes may be interpreted, there is general agreement among commentators in perceiving $C .1 .9$, the "Soracte Ode", as both the culmination of the opening sequence and the signature poem for the rest of the collection, which progressively looks to Alcaeus as its principal model. One can read odes $1.12-1.18$ as a kind of second "Parade" where intertextual allusions to Greek lyrical models may be more clearly detected than earlier. ${ }^{222}$ Horace however takes such echoes and mottos simply as a starting point before apparently developing his lyric in quite different ways, thus asserting both his similarity to and difference from his predecessors. ${ }^{223}$

\footnotetext{
220 Davis (1991) 29.

221 Michael Putnam (1995) 56ff. also points out a similar contrast between the epithets levis and gravis in this ode, where the author's declared "levity" prevents him from commenting on the "grave" subjects of Homeric myth that he mentions (1.6.5-8). Yet the use of warlike lexis (proelia, acrium) in the final stanza as a metaphor for the contests of young lovers that Horace claims as his poetic domain has, in Putnam's view "a rich resonance in a lyric whose essential subject has hitherto been a refusal to write epic".

222 Lowrie (1997) 339. She links C. 1.12 to Pindar, 1.13 to Sappho, 1.14 to Alcaeus, 1.15 to Bacchylides, 1.16 to Stesichorus, 1.17 to Anacreon and 1.18 again to Alcaeus to close the series.

223 Lowrie (1997) 337.
} 
With C. 1.16 and 1.17, Horace rounds off his preliminary metapoetic excursus, with both poems being in Alcaic metre and exactly the same length, so reinforcing the commitment to the Alcaean lyric model made at C. 1.9. C. 1.16 is a "palinode" or poem of recantation, where the poetic persona asks his mistress to dispose of his hasty invective verses (iambis) that he now regrets sending her. The central part of the ode consists of a disquisition on the destructive effects of anger. On the metapoetic level, however, both Davis 224 and Lowrie ${ }^{225}$ interpret the poem as Horace's definitive distancing himself from the iambic form he essayed in the Epodes. But neither commentator draws any conclusions from this interpretation as to who the "daughter more beautiful than her beautiful mother" (C. 1.16.1) might be. Yet a metapoetic reading suggests that the filia pulchrior is Horace's personification of Latin poetry which, while acknowledging its parentage in Greek literature, is now maturing into a more beautiful expression still and needs to be treated with proper regard. C. 1.17 then stands as the positive counterpart of the preceding renunciation. Here, Horace celebrates the acclimatisation of Greek lyric forms and themes to Italian poetic landscapes, at the heart of which he positions himself (C. 1.17.13-14). To this Italian environment the poet invites his addressee, Tyndaris, who may be linked back to the filia pulchrior of the previous ode. ${ }^{226}$ In the fifth stanza, Horace asserts a generic enrichment of his lyric compass by evoking the singing of mythic and Homeric themes accompanied by the strings of Anacreon: fide Teia (C. 1.17.18). The grand themes disavowed in $C$. 1.6 are now being embraced within the legitimate bounds of Latin lyric. ${ }^{227}$

At C. 1.20, the median poem of Book 1, the poet reconnects with his principal addressee, Maecenas, with an invitation to a quiet drink together, a trope which will be repeated in the final poem of the book, $C$. 1.38. This short poem ushers in a change of register, introducing a series of generally short sympotic-erotic poems (C. 1.20-1.30) that on the

\footnotetext{
224 Davis (1991) 76.

225 Lowrie (1997) 349.

226 Her name links her to Helen, but now transposed to a new land.

227 Davis (1991) 201 also perceives an extended intertextual allusion between C. 1.17 and Virgil's Ecl. 1.15. The multiple lexical echoes between these two texts (at least 6) suggest that in this ode Horace is also acknowledging his debt to and aesthetic solidarity with the new poetic directions charted by Virgil.
} 
surface affirm traditional lyric themes, but beneath which Horace subtly places other markers which quietly stake his claim to a broader range for his lyric.

The final eight poems ( $C$. 1.31-38) bring the focus back to more reflective themes. At $C$. 1.31 the role of the poet in public affairs is raised again, in the context of the dedication of the restored temple of Apollo in 28 BCE. For the first time since C. 1.1., the term vates is employed for the poet who fulfils such public functions. In C. 1.32, the Alcaean lyre is invoked as the specific instrument for Horace's verse. Significantly here, Alcaeus is referred to first in his role as civis, taking part in the public life of his city, then as one able to sing erotic and sympotic poems in the private sphere. As we have already analysed, Odes 34-37 then engage philosophical and political themes, so acting as a counterweight to the opening poems of the book. This set is bound together by the polysemic resonances created by the considerable number of lexical recurrences between them that we observed.

The final brief two-stanza C. 1.38 has, however, perplexed many commentators. Some, like Nisbet and Hubbard and Fraenkel ${ }^{228}$ have concluded that the poem must have special relevance due to its position, yet they remain unclear what this might be. Others though, even Günther very recently, dismiss any idea of a programmatic function. ${ }^{229}$ Davis, on the other hand, finds in it a general résumé of Horace's aesthetic principles. ${ }^{230}$ For Davis, the "organizing principle" of $C .1 .38$ is the image of the corona (1.38.2), the metonymic symbol for poetry, noting that the poet rejects excessive ornateness in such wreaths in preferring his brow to be set with plain myrtle (1.38.5). Davis finds here a clear allusion to the Callimachean aesthetic of the Aetia prologue, a conclusion reinforced by Horace's dislike for "Persian preparations" (Persicos apparatus: 1.38.1) which echoes the schoinos Persidês of Aetia fr. 1.18, a measuring-rod which Davis interprets as being dismissed by Callimachus as a determinant of poetic excellence. ${ }^{231}$

\footnotetext{
228 Nisbet \& Hubbard (1970) 423; Fraenkel (1957) 298.

229 Günther (2013) 216.

230 Davis (1991) 118.

231 Davis (1991) 120. Callimachus' full assertion states: "judge poetry by its art (technê), not by the Persian chain" (fr. 1.17-18). It was artistry, not length, that was to be the chief criterion. But Callimachus did not mean by this that long poems should not written.
} 
Through such allusions, reinforced by the simple brevity of his final ode, Horace closes Book 1 by reasserting his commitment to Alexandrian poetics. But more importantly, in my view, is the poet's re-engagement here with the reader via the figure of the servant who is invited to a private symposium with him, in the manner of Maecenas at C. 1.20. The servant-reader is gently dissuaded from looking for the elaborate and exotic in Horace's verse (C. 1.38.5) while being recognized as an equal partner in the creation and reception of high-quality poetry: neque te ministrum /dedecet myrtus neque me: $C$. 1.38.6-7. Tellingly, the absence of Maecenas from this pivotal poem demonstrates that the intended audience is not to be determined by social status but by the capacity to appreciate the poet's artistry.

By thus aligning poet and reader in a common enterprise, C. 1.38 completes the development phase of the total lyric opus. Book 1 has laid out the metrical, generic, thematic and aesthetic parameters. The work is firmly grounded in the Greek tradition, but clear indicators have been given to how that tradition will be sublimated within the new Latin cultural environment. A range of poetic products has been presented in which the light and slender (tenue) has been predominant, but with sufficient indication of the capability of the lyric form to address serious themes. By inviting the now-prepared reader to join in the symbolic symposium of $C .1 .38$, Horace now looks ahead to engaging that reader in the more serious reflections of Books 2 and 3.

If we resume the musical analogy, Book 2 may then be described as the sedate movement. It displays considerable uniformity in form and metre, with Alcaics and Sapphics alternating over the first eleven of twenty poems, and with only C. 2.12 and 2.18 not in these metres. There are no very long or short poems, with thirteen being of either 24 or 28 lines. Thematically, most odes are devoted to moral or philosophical topics but whose earnestness is leavened with humour and amicitia. ${ }^{232}$

${ }^{232}$ Günther (2013) 321 identifies Book 2 as a "book of friends" presenting as a collection of "private conversations." 
The first ode, $C .2 .1$, echoes $C .1 .1$ in taking a priamel form, although now the different endeavours are evoked through the achievements of the addressee, Asinius Pollio. He is shown as respectively an historian, tragedian, orator, politician and successful general. Horace then selects one of these aspects, Pollio's history of the civil wars, through which to refract his own commentary on the brutality of these conflicts before disclaiming any intent to pursue this theme in a brief recusatio in the final stanza. But while outwardly chastising his "mischievous Muse" (Musa procax) from drawing him away from lighter themes, Horace is now effectively signalling the appropriateness of the lyric form to engage with more serious matters.

Such an enterprise, though, is then deferred for a time, since the following ten odes are ostensibly limited to counselling their respective addressees to adopt the guideline of the "golden mean" for their public and private lives. In C. 2.2, Sallustius is commended for his "temperate" outlook on money. In C. 2.3, Dellius is urged to pursue an Epicurean enjoyment of life given that death is inevitable. In 2.6, the poet reverses the perspective, acknowledging the comfort in his old age that he expects from the companionship of his young friend Septimius, and which will safeguard his poetic reputation.

The te mecum theme of $C .2 .6 .21$ is then pursued in C. 2.7.1: o saepe mecum tempus in ultimum, within the more serious setting of embracing an old comrade from the defeat at Philippi. But the brief evocation of the battle in stanzas 3 and 4 (of 7) is enclosed within a framework of convivial drinking parties taking place both before and after it. Horace is thus carefully framing the political dimension within the traditional generic ambit of lyric, while taking care not as yet to accord it too much prominence.

C. 2.10 stands at the mid-point of Book 2 and, with its now explicit recommendation of the pursuit of auream ... mediocritatem at line 5, effectively summarises the thematic tenor of the first half of the book. But the poem may also be read as proposing this "middle way" as an aesthetic objective. Lyric poetry should avoid on the one hand the trite and hackneyed, represented in the image of the tectum obsoletum (C. 2.10.6-7), but also on the other, themes that are too elevated and likely to invite jealousy or sneering, suggested by the aula invidenda (C. 2.10.7-8). 
Nevertheless, Horace in the next stanza does cautiously press his claim to a dual role for his lyric with intertextual allusions back to two key poems of Book 1: C. 1.9, the "Soracte ode" in the image of the storm-ravaged pines, and C. 1.2 in that of thunderbolts smiting the highest mountain-tops. ${ }^{233}$ In 1.9, the poet advises an Epicurean quietist disregard for things that cannot be controlled, while in $C .1 .2$ he issues a call to repentance for the evils caused by the civil war. In C. 2.10 , these two tones of the poetic voice are drawn together in the penultimate stanza in the image of Apollo in his role as god of poetry:

\author{
non, si male nunc, et olim \\ sic erit ; quondam citharae ${ }^{234}$ tacentem \\ suscitat Musam neque semper arcum \\ tendit Apollo. (C. 2.10.17-20)
}

If things are bad now, they will not always be so: at times Apollo wakes the silent Muse of the lyre; he does not always keep his bow taut. (trans. Rudd 2004)

Apollo's awakening of "Muse of the lyre" in certain difficult circumstances suggests that lyric may at times mediate serious political issues which do not always have to be addressed in the grand style of epic implicit in the image of the god bending his bow.

The final nine odes of Book 2 then bring the focus back to the role Horace projected for himself. In C. 2.12 he apparently concedes to others (specifically to Maecenas, in prose) the task of writing on historical, mythical and political subjects (stanzas 1-3) while he reserves for himself lighter erotic themes (stanzas 4-7). But this is immediately nuanced in C. 2.13 where the near-fatal accident with the falling tree allows him to anticipate joining the company of Sappho and Alcaeus in the Underworld. But it is to Alcaeus that

233 Compare 2.10.9-12: saepius ventis agitatur ingens / pinus et celsae graviore casu / decidunt turres feriuntque summos /fulgura montis with C. 1.9.9-12: qui simul / stravere ventos aequore fervido / deproeliantis, nec cupressi / nec veteres agitantur orni, and C. 1.2.2-4: et rubente / dextera sacras iaculatus arces / terruit urbem. The "sacred citadel" here is that on the Mons Capitolinus, the "highest" mountain of Rome in the political sense, smitten by Jupiter's bolts in punishment for the civil wars.

234 Nisbet \& Hubbard (1978) 164 prefer the genitive variant citharae to the more frequently accepted ablative citharā, arguing that "the music is latent in the lyre and does not have to be evoked out of the air." I believe this fits the sense better. 
he appears to give pre-eminence, emphasizing how the latter's treatment of political themes had greater audience appeal over Sappho's lighter erotic lyrics. ${ }^{235}$

C. 2.16 returns to earlier themes of the book, contrasting the contentment (otium) offered by a simple rural life with the anxieties that accompany wealth. But in the final stanza the poet conflates this simplicity with the slender spirit of his now "GrecoItalian" Muse (C. $2.16 .37-39) .{ }^{236} \mathrm{He}$ is thus asserting his security in an Italian poetic identity derived originally from Greece, as previously in $C .1 .17$, but one also grounded firmly within the Alexandrian aesthetic.

The Callimachean association is reinforced in C. 2.19 , the "Ode to Bacchus". In the Augustan age, poets treated Bacchus as a source of their inspiration, and Callimachus too associated Dionysos/Bacchus with the Muses, regarding him as responsible for poetic inspiration. ${ }^{237}$ In this ode, the poet imagines himself as an ecstatic Bacchant (stanza 2) in which state the god gives him permission to sing not only lyric-bucolic themes (stanza 3), but also mythical ones (stanzas 4-6). Furthermore, while in stanza 7 the god-filled lyric poet is considered more suitable for singing lighter themes and illequipped for martial ones, nevertheless that poet may also take up the central place Bacchus occupied in matters of peace and war: sed idem pacis eras mediusque belli ( $C$. 2.19.28).

By the end of Book 2, through both demonstration and aesthetic argument, Horace has drawn his audience to a point where they may accept the suitability of lyric to extend

${ }^{235}$ C. 2.13.30-32: sed magis / pugnas et exactos tyrannos / densum umeros bibit aure vulgus. Feeney (1993) 49 declares: "The stark polarization of the Lesbian tradition is partly Horace's way of continuing from C. 1.32 his process of homing in on Alcaeus as a model for the more resonant voice he wants to claim". Davis (1991) 85-86 takes the opposite view, observing "Alcaeus and Sappho here stand [...] for two complementary generic poles available to Horace within the Lesbian tradition - namely, a more public-oriented one, concerned with the welfare of the polis, [...] and a more inner-directed one, involved with light and often erotic subject matter". Davis concludes: "Rather than stating an outright preference, [Horace] is seeking to define the kind of sophisticated audience of docti required for the variety of lyric he espouses in the Odes".

236 We note the repetition of the adjective tenuis from 2.16.14: splendet in mensa tenui salinum referring to the frugal board of the rural dweller, in 2.16.38: spiritum Graiae tenuem Camenae.

237 Nisbet \& Hubbard (1978) 316. 
to all poetic domains. With C. 2.20 he now sets aside the pretence of being simply tenuis in his poetic role. ${ }^{238}$ He foresees he will be borne aloft as a "poet of double-shape" (vates biformis) on wings that are neither well-worn nor slender: non usitata nec tenui ferar / penna (C. 2.20.1-2). His imagined metamorphosis into a bird, however, has bemused some commentators ${ }^{239}$ with a variety of interpretations offered. Nisbet and Hubbard perceive in the description the transformation of Horace's earthbound temporality into the enduring reputation of a universal poet. ${ }^{240}$ This interpretation is reinforced by the anticipated geographic spread of his future readers in stanzas 4 and 5. But this does not really account for the duality of the poet's shape. For once the universal has been assumed, the temporal is left behind. Given the metapoetic argument developed in Book 2, however, the vates biformis may perhaps be better interpreted as one who adopted the refined slenderness of the Alexandrian aesthetic but in such a way as to be equally capable of embracing the grand themes normally borne aloft by more robust genres.

There remains the question of this poem's placement in the entire opus. Its claim to immortality suits the end of a collection. ${ }^{241}$ But it merely concludes the second of three books. What it might rather be doing, through the trope of the metamorphosis, is to mark in a startling manner that a major change in the poetic voice and persona is taking place at this point in the overall poetic development of the opus, whose effects will become immediately apparently in Book 3 . The clinching evidence for this may be that, as in C. 1.1, the verbs describing the poet's ambition are still in the future tense: ${ }^{242}$ ferar (C. 2.20.1), neque ... morabor (2.20.3), relinquam (2.20.5), non ... obibo (2.20.7), nec ... cohibebor (2.20.8), visam (2.20.14), noscent (2.20.19), discet (2.20.20). Although now without the cautious quodsi conditional of $C .1 .1 .35$, the venture still has to be finally realized. The reader is now being invited to accompany Horace on the final step of that journey to poetic immortality.

\footnotetext{
238 Nisbet \& Hubbard (1978) 338, Feeney (1993) 52.

239 Feeney (1993) 52, for example, finds it "remorselessly hilarious."

240 Nisbet \& Hubbard (1978) 337.

241 Nisbet \& Hubbard (1978) 337.

242 Exceptions are the verbs of stanza 3 which are all in the present tense, describing the metamorphosis actually taking place.
} 
With the opening six poems of Book 3, commonly referred to as the "Roman Odes", Horace fully reclaims the public, prophetic role of the vates that he had first asserted in Epode 16. All six poems are in the Alcaic metre and of substantial length, but none has an individual addressee. Instead, the poet addresses the youth of Rome (virginibus puerisque: C. 3.1.4) on themes of social, moral and religious regeneration. He proclaims himself the priest of the Muses (Musarum sacerdos: $C$. 3.1 .3$)^{243}$ who is singing them songs never heard before (carmina non prius audita: $C$. 3.1.2-3). Such songs are new not only for their Aeolic metres, but for their engagement of their audience through the dialogic form of lyric which had never been attempted before in Latin poetry.

The startling opening of C. 3.1: odi profanum vulgus et arceo / favete linguis, invites the Roman Odes cycle to be read metapoetically as well. On the immediate level, the phrase reflects the sacred formulae uttered at the start of religious ceremonies ${ }^{244}$ from which the "profane crowd" were excluded. This association in turn lends an oracular status to the priest-poet's utterances. But profanum vulgus echoes the malignum vulgus of $C$. 2.16.39-40 which Fate had led the poet to spurn, and his self-distancing (arceo) from the crowd recalls Horace's claim in C. 1.1.32 that in his role as poet, the gods mark him off from the people (me ... secernunt populo). Interpreted metapoetically, Horace is declaring in $C$. 3.1 that his carmina require the discernment of highly attuned readers if their full import is to be comprehended. This then becomes an instruction as to how to read the Roman Odes in particular, but also in retrospect, the whole collection.

After this portentous opening, however, C. 3.1 surprisingly does not pursue the anticipated public prophetic utterance, but is devoted to recommending "Epicurean quietude." 245 Nevertheless a metapoetic reading reveals that the remaining stanzas of

\footnotetext{
243 Newman (1967) 20 perceives in Musarum sacerdos an echo of the official Alexandrian title of hiereus tôn Mousôn, once held by Apollonius of Rhodes, but comments: "for Roman poets, no such title existed, giving them greater freedom in its use". Equally strong, though, is the echo of Aeneid 6, almost certain to have been known by Horace in its pre-published form by the later 20s BCE, where the Sibyl who reveals Rome's future to Aeneas is referred to as vates (13 times) and sacerdos ( 7 times), and where, says Newman (35) "the religious and poetic aspects of vates become intermingled in an Apolline context".

244 Fraenkel (1957) 264.

245 Lyne (1995) 162.
} 
the ode largely revisit the themes and aesthetic issues Horace gradually developed over the first two books. In stanza 2, with the dual reference to the place of kings in the universal order (regum timendorum in proprios greges, / reges in ipsos imperium est lovis: $3.1 .5-5)$ the poet is claiming the authority to speak of such high matters within the compass of his lyric, while the reference to the Gigantomachy $(C$. 3.1.7) both extends this compass to myth and foreshadows the more extensive examination of this theme in C. 3.4. Stanzas 3-10 then form a kind of inverse proem invoking themes covered in earlier odes. ${ }^{246}$ But by including these themes in a poem claiming a public prophetic role, Horace elevates the whole of his poetry to the universal level. Public and private spheres now become merged.

From this perspective, the poet's own personal pursuit of quietude expressed in the final two stanzas takes on a more complex meaning. Why, the poet rhetorically asks, given the disadvantages arising from the pursuit of wealth which he has just laid out, should he then give up the peace of his rural retreat ${ }^{247}$ From the private point of view, all his poetry to this point has rejected such a way of life. But for the public vates, such retirement from society may not be an option. At C. 2.10, the "golden mean" was leading the poet away from constructing an invidenda aula, but his claimed vatic role now means he may need to risk raising a "sublime atrium." 248 Likewise, though the quiet of the Sabine valley is appealing, if the poet's destiny is to direct his society to where its true riches (divitias) may be found, he may have to undertake some heavy labour. The massive final six-syllable word operosiores provides a measure of how daunting a task that might be.

C. 3.2 then resumes the public role, promoting military virtue, but presenting little more than a series of "trenchant aphorisms". ${ }^{249}$ Odes 3.3, 3.4 and 3.5 are the most substantial

\footnotetext{
${ }^{246}$ E.g. contending election candidates ( $c f . c .1 .1$ ), the universal equality before Fortune ( $\left.c f .1 .35\right)$, rural tranquillity (cf. $C .1 .17,2.3,2.6)$, acceptance of what is enough ( $c f . C .1 .31$ ), the social consequences of extreme wealth (cf. C. 2.15) and its associated worries (cf. C. 2.16, 2.18).

247 C. 3.1.45-48: cur invidendis postibus et novo / sublime ritu moliar atrium, / cur valle permute Sabina/ divitias operosiores?

248 There is a perceptible echo here of $C$. 1.1.36: sublimi feriam sidera vertice. But instead of the confident future tense of feriam, the poet now deploys an uncertain present subjunctive moliar, whose sense Nisbet and Rudd (2004) 20 interpret as "the effort to raise a pile".

249 Nisbet \& Rudd (2004) 22 report it as "now the least admired of the Roman Odes".
} 
of the set in terms of their length, prophetic content and the complexity of their lyric structure. As Günther notes, ${ }^{250}$ C. 3.3 and 3.5 both are constructed around long speeches by Juno and Regulus, providing a frame for $C$. 3.4 which locates Caesar at its centre. Lowrie observes that the three extended narratives incorporated into these poems "cover the range of available epic - Homeric (C. 3.3), Hesiodic (C. 3.4) and historical (Ennian) (C. 3.5) - all of it made Roman". ${ }^{251}$ They demonstrate Horace's generic enrichment of lyric to its broadest extent, where the poet draws on epic themes from these sources as allegories for the commentaries he is making on his own times. :

This is made explicit in C. 3.4, where the poet invites Calliope, the Queen of the Muses and the one invoked most frequently by Pindar, to sing a longum melos (C. 3.4.2), accompanied either on her shrill pipe or on Phoebus' lyre. ${ }^{252}$ Here, Horace is not only intentionally embracing a longer form as appropriate for his lyric, but identifying two distinct spheres for its reception: the public sphere, through choral lyric (tibia) and the private, through monodic lyric (cithara). Yet the poet is not here writing a choral ode per se, but a monodic ode that invites reading as a choral ode. The public and private voices of the vates biformis are being blended, prompting his private audience of amici docti to hear a prophetic public utterance in the poem. The first line of the second stanza: auditis an me ludit amabilis / insania? shows he is still anxious about his reception.

C. 3.5 and 3.6 complete the prophetic cycle. C. 3.5 addresses the as yet unexpunged disgrace of Carrhae by reflecting it through the story of Regulus, while warning against excessive trust in national grand narratives that conceal flaws. C. 3.6 issues a call for religious and moral renewal. But despite the specific historical references, the vatic stance has shifted the domain of the commentary from the actual to the universal. ${ }^{253}$ Lowrie asserts that "Horace represents the present as a bleak moment on the verge of renewal". ${ }^{254}$ But by "the present" we might interpret not just, or even principally (and

\footnotetext{
250 Günther (2013) 386.

251 Lowrie (1997) 228.

252 dic age tibia ... seu fidibus citharaque Phoebi, C. 3.4.1, 4, echoing the similar question directed to the muse Clio in C. 1.12.1-2 noted earlier.

253 This provides an answer to the earlier question about the continuing topicality of poems about the civil war well after social order had been restored.

254 Lowrie (1997) 256.
} 
even for Horace's first audiences) the historical moment of poetic composition, but the universal present of poetic utterance.

After the substantial weight of the Roman Odes, however, Horace changes tone and register completely. The 17 poems from C. 3.7-3.23 return to a range of lighter themes, and varying lengths and metres not found since the middle section of Book 1 , with Alcaics used only three times. While the Roman Odes may have brought to fruition Horace's role as a public poet, the continuation of the opus in lighter vein suggests he did not want his lyric project to climax with them. The implicit message may be that the restoration of a peaceful, orderly and morally sound society then allows for the enjoyment of the otium which makes life worth living. After the grande has been encompassed, it is the tenue of life which eventually gives the most satisfaction.

Nevertheless, while these central poems of Book 3 reassert the personal dimension of lyric, equally the collection would trail away rather feebly if it ended with them. As with Book 1, therefore, Horace gradually builds to a climax in the final section (C. 3.24-30); by their length, ${ }^{255}$ serious themes and resumption of mythic narrative (particularly in $C$. 3.27, the "Europa Ode"), these poems counterbalance the Roman Odes at the beginning of the book. But in contrast to the earlier sequence, there is no common tone or register. Instead, in a kind of "final parade", Horace lays out the whole range of his lyric achievement (C. 3.24-29) before declaring his task complete at $C$. 3.30.

In particular, in the brief three-stanza C. 3.26, Horace appears to acknowledge that his career as a poet of light themes is also now over. The first two lines: vixi puellis nuper idoneus / et militavi non sine gloria, recall the final stanza of $C$. 1.6, where the poet asserted his greater talent for the battles of love than of war, while the next three lines: nunc arma defunctumque bello / barbiton hic paries habebit / laevum marinae qui Veneris latus / custodit, recall the ultimate stanza of $C .1 .5$, the "Pyrrha Ode", where the poet had claimed he was already retired from the sea of love. This renunciation of love

\footnotetext{
255 However, an artful balance is maintained between odes 3.24 and 3.29 (64 lines) and 3.27 (76 lines) on the one hand and odes 3.25 (20 lines), 3.26 (12 lines) and 3.28 and 3.30 (16 lines) on the other.
} 
poetry is reinforced in C. 3.28 where, at a party in Neptune's honour, Venus will have the last song: summo carmine (C. 28.13).

At C. 3.29, Horace resalutes Maecenas with a form of address, Tyrrhena regum progenies, which recalls the apostrophe: atavis edite regibus of $C$. 1.1.1. The poem invites the patron to lay down the burdens of political involvement and stop worrying about the state. It then gradually morphs into a valedictory for the poet's career. In images that recall the turbulent maritime scenes evoked in $C .1 .14,{ }^{256}$ reckoned as one of his earliest odes, ${ }^{257}$ Horace now entrusts himself to the protection of his "twin-oared skiff": biremis praesidio scaphae, fearless that he will be carried to safety with his task now complete.

But why specify a scapha biremis here? The epithet is otherwise otiose, as a small boat obviously needs at least one pair of oars to propel it. But given that the skiff is a metaphor for the work of poetry that Horace is in the process of launching and which he now expects will carry him to immortal fame, we may detect in biremis an echo of the biformis describing the vatic poet's metamorphosis in the final poem of Book 2. In that sense, for his poetic message to travel in a straight line, it needs two oars, Callimachean form and Augustan substance. ${ }^{258}$

With $C$. 3.30, Horace brings his lyric project to what he imagines will be its definitive conclusion. In contrast to the forward-looking future tenses of $C .1 .1$ and $C .2 .20$, the first word, exegi, is a proudly assertive perfect tense, with the three long syllables pointing to the monumentum the verb governs. The poet reasserts his claim to have been the first to have spun Aeolic song to Italian tunes (C. 3.30.13-14). But the phrase Aeolium carmen ad Italos / deduxisse modos evokes an intertextual allusion to Virgil's Ecl. 6.5: pastorem, Tityre, pinguis / pascere oportet ovis, deductum dicere carmen, which

256 Compare C. 29.57-59: non est meum, si mugiat Africis / malus procellis, ad miseras preces / decurrere et votis pacisci with C. 1.14.5 : et malus celeri saucius Africo and 1.14.9-10 : non tibi sunt integra lintea I non di quos iterum pressa voces malo.

257 Nisbet \& Hubbard (1970) 181.

258 The "frail skiff" could also allude to the light Liburnian galleys sculling between the tall ships of Epode 1 , equally dedicated to Maecenas. 
in turn alludes incontrovertibly to the Aetia prologue. Thus Horace may be seen to be equally acknowledging in this ultimate ode his continuing allegiance to the Alexandrian aesthetic.

Finally, Horace calls upon the Muse Melpomene to crown him with the Delphica lauro (C. 3.30.16). He is no longer content with the ivy crown of poets he claimed in the first poem of the collection. The laurel crown was awarded to triumphant generals (as to Pollio at C. 2.1.15), but also to victors of poetry contests at the Pythian Games. Horace was thus seeking the laurel of Delphic Apollo, the god "particularly associated with prophecy". 259

Considering these two final allusions, we may reasonably conclude that with this poem, Horace was declaring his dual project achieved. He had created a uniquely innovative form of poetry by transposing the metres, themes and registers of Aeolic lyric to Latin, but shaping them according to the demanding precepts of Alexandrian artistry. This form he then used as a vehicle for engaging the discerning and highly literate audience he had cultivated throughout his literary career in an intense dialogue about the social, political, moral and cultural well-being of the state. From that point of view, with the completion of the lyric opus Odes 1-3, there seemed nothing left for him to achieve.

259 Nisbet \& Rudd (2004) 377. 


\section{Conclusion}

This investigation arose out of the observation of patterns of word repetition that occur across pairs, sequences or clusters of adjacent poems throughout the three books of Horace's Odes. The initial questions prompted by this observation were whether these patterns of lexical recurrence could be attributed to an intentional process of poetic composition on the part of the author, and concomitantly whether they were a determining factor in the manner in which the individual poems of each book were ordered. Regardless of what conclusions might be drawn from a consideration of these questions, however, the demonstrable presence of such patterns of recurrence over the whole Odes 1-3 opus also posed the challenge of interpreting the specific poetic effects that perception of such recurrences might elicit.

My initial statistical analysis of the occurrences of particular lexemes, together with my research of the philological evidence derived by reputable commentators of Latin literature, led to the establishment of two axioms:

(i) that there is no statistically significant greater occurrence of lexical repetition over contiguous poems in the received published order of the Odes than would be shown by any random ordering of the same poems;

(ii) that the order in which the individual odes of each book are universally presented was almost certainly determined by Horace himself at the time of publication of the collection.

From the first of these, it is certainly possible to maintain that the recurrence patterns are purely fortuitous and that as a consequence they played no part in determining the order of the poems. However, given the large number of such contiguous recurrences observed, a more likely scenario could be that, while many, and perhaps most, such occurrences are indeed chance ones, nevertheless it is jejune to imagine that some of the more marked repetitions, particularly those occupying equivalent or near- 
equivalent locations in consecutive poems, were not the result of intentional placement by the author. Those identified in the early poems of both Books 1 and 2 are good candidates for this conclusion. At all events, even if these repetitions were not the result of active placement by the poet, it may be fairly deduced that one as acutely attuned to poetic structure as Horace would have been aware of them and left them in place as part of the poetic effects he was seeking to create.

From the second axiom it can be affirmed that, whatever the general ordering principle was that Horace adopted, the order he chose does effectively create the particular lexical associations observed. My analysis of the poetic project of which Odes 1-3 was the culmination has postulated that the major ordering principle involved was the poet's dialogic engagement with his audience by which he sought to lead readers step by step through the metapoetic process of accepting new metrical, generic and aesthetic parameters for his poetry before then using this new vehicle as a means of addressing matters of significant social, moral and cultural importance. Hence, while creating lexical linkages may not have been the determinant of the juxtaposition of the poems they are part of, nevertheless they become an effect of that location. This effect in the first instance is to tie individual poems into the developing opus, hence reinforcing the importance of the whole work over its constituent parts.

From the point of view of the reader, however, it is the secondary effect of the patterns of lexical recurrence which becomes most significant for the interpretation of the work. This secondary effect is that which becomes perceptible when the work is re-read. That Horace composed his work with the expectation that its quality would not be fully appreciated until it was subjected to iterated reading by a perceptive and erudite audience is clear from his commentaries in the Satires and the Epistles. Such re-reading then becomes the invitation to that audience to construct meaning from their dialogue with the poem's text. It is within such a context that the lexical echoes exercise their creative effect, as I demonstrated in the analysis of Odes 1.34-38.

For, if we consider reader-reception in Jaussian terms, the initial perception of the patterns of repetition - a perception which would be enhanced by the process of 
sequential reading imposed by the ancient book-roll format - creates a horizon of expectation for any subsequent reading. The encounter with an identical or closelysimilar lexical form shortly after initially meeting it sets up a disturbance in the receptive flow of the reading, leading to a potential recall of the earlier usage, hence establishing an association between the two poems of which these paired terms are part. Such associations become even more sharply focused if there are several such pairs linking the two poems involved.

The creation of such vortices in the reading flow thus influences the expectations of second and subsequent readings, for when the first usage of the associated pair is encountered anew in that second reading, it calls to mind in advance the later usage, by Husserl's process of "protension". Through engaging in this both prospective and retrospective process, the reader is induced to concretize meaning from this complex interplay of forces between the two poems. The texture of this meaning will become more multi-layered and complex the more linkages are perceived between the particular two poems, and then by extension, by associations that each of them have with other poems of the collection. Hence, meaning is constantly open to new creation. Appreciated in this way, it is otiose to consider whether any particular meaning that an individual reader may generate from the text was intended by the author. But nor thereby is it correct to assume that the author, in this case Horace (or more strictly, the secondary author "Horace" whose consciousness suffuses the text) is entirely divorced from that meaning generation. The poet's artistry lies in inducing a process of reading whereby such meaning can be created.

Horace's whole poetic career up to the publication of Odes 1-3 can thus be interpreted as directed towards such an end. The first task was to lay out the aesthetic parameters that would govern his art and build a supportive and discerning audience able to engage with the poet in an author-reader dialogue initiated by his texts. The second was to find a poetic form sufficiently novel and challenging to stimulate that engagement. lambic appeared to offer such a form by its associations with dramatic dialogue, but could not be divested of its invective dimension. Aeolic lyric proved ultimately more capable of achieving the required end. Once this genre was adopted and moulded by Horace to fit 
a Roman social, cultural and aesthetic climate, the poet sought by measured steps to transmute a work of writing into a work of reading. In this way the completed monumentum he set forth for his readers in C. 3.30 has indeed proved aere perennius, in that it continues to engage an interpretive community of amici docti taught by the poet how to read. 


\section{Bibliography}

\section{Primary Sources}

A. Horace

Satires 1

Satires 2

Satires, Epistles, Ars Poetica

Odes and Epodes

B. Other Authors

Aristotle, Poetics

Callimachus, Aetia lambi

Catullus

Cicero, De Officiis

Greek Lyric:

Ovid, Tristia

Pliny the Younger, Epistles

Quintilian, Institutio Oratoria

Suetonius, Vita Horati De Grammaticis

Virgil, Eclogues, Aeneid
Brown, P. Michael (ed. and trans.) (Warminster, 1993) Muecke, Frances (ed. and trans.) (Warminster, 1991)

Fairclough, H. Rushton (ed. and trans.) (Cambridge, MA, 1961)

Rudd, Niall (ed. and trans.) (Cambridge, MA, 2004)

Lucas, D.W. (ed.) (Oxford, 1968)

Harder, Annette (ed.) (Oxford, 2012)

Trypanis, C. A. (ed. and trans.) (Cambridge MA, 1975) Cornish, F. W. (ed. and trans., rev. G. P. Goold) (Cambridge MA, 1988)

Miller, Walter (ed. and trans.) (Cambridge MA, 2005)

Campbell, David A. (ed. and trans.) (Cambridge MA, 1988)

Wheeler, Arthur Leslie (ed. and trans.) (Cambridge MA, 1965)

Melmoth, William (ed. and trans., rev. W. M. L. Hutchinson) (London, 1923)

Russell, Donald H. (ed. and trans.) (Cambridge MA, 2001)

Carew, John (ed. and trans.) (Cambridge MA, 1995)

Carew, John (ed. and trans.) (Cambridge MA, 1995)

Fairclough, H. Rushton (ed. and trans.) (Cambridge MA, 1965)

\section{Secondary Sources}

Acosta-Hughes, Benjamin and Susan A. Stephens (2002) "Rereading Callimachus' Aetia Fragment 1", CP 97: 238-55.

(eds) (2012) Callimachus in Context. From Plato to the Augustan Poets (Cambridge).

Armstrong, David (2010) "The Biographical and Social Foundations of Horace's Poetic Voice", in Davis (ed.) 7-33.

Barbantani, Silvia (2009) "Lyric in the Hellenistic Period and Beyond", in Budelmann (ed.) 297-318.

Barchiesi, Alessandro (2001) "Horace and lambos: The Poet as Literary Historian", in A. Cávarzere, A. Aloni, and A. Barchiesi (eds) lambic Ideas: Essays on a Poetic Tradition from Archaic Greece to the Late Roman Empire (Lanham, MD) 141-64.

(2007) "Carmina: Odes and Carmen Saeculare", in Harrison (ed.) 144-61. 
Batstone, William W. (2006) "Provocation: The Point of Reception Theory", in Martindale and Thomas (eds) 14-20.

Bonavia-Hunt, Noel A. (1969) Horace the Minstrel. A Practical and Aesthetic Study of his Aeolic Verse (Kineton, UK).

Bowditch, Phebe Lowell (2001) Horace and the Gift Economy of Patronage (Berkeley).

Budelmann, Felix (ed.) (2009) The Cambridge Companion to Greek Lyric (Cambridge). (2009) "Introducing Greek Lyric", in Budelmann (ed.) 1-18.

Cameron, Alan (1995) Callimachus and his Critics (Princeton).

Carey, Chris (2009) "Genre, Occasion and Performance", in Budelmann (ed.) 21-38.

Clauss, James J. and Martine Cuypers (eds) (2010) A Companion to Hellenistic Literature (Malden, MA).

Collinge, N. E. (1961) The Structure of Horace's Odes (London).

Conte, Gian Biagio (1986) The Rhetoric of Imitation. Genre and Poetic Memory in Virgil and Other Latin Poets (Ithaca, NY). (1994) Latin Literature. A History (Baltimore).

Davis, Gregson (1991) Polyhymnia. The Rhetoric of Horatian Lyric Discourse (Berkeley). (ed.) (2010) A Companion to Horace (Malden, MA).

DuQuesnay, I. M. Le M. (1984) "Horace and Maecenas. The propaganda value of Sermones 1", in Tony Woodman and David West (eds) Poetry and Politics in the Age of Augustus (Cambridge) 19-58.

Edmunds, Lowell (2001) Intertextuality and the Reading of Roman Poetry (Baltimore). Esposito, Elena (2010) "Herodas and the Mime", in Clauss and Cuypers (eds) 261-81.

Feeney, Denis (1993) "Horace and the Greek Lyric Poets", in Niall Rudd (ed.) Horace 2000. A Celebration. Essays for the Bimillennium (Ann Arbor) 41-63.

(2009) "Becoming an authority: Horace on his own reception", in L. B. T. Houghton and Maria Wyke (eds) Perceptions of Horace. A Roman Poet and His Readers (Cambridge) 16-38.

Fitzgerald, William (2009) "Power and Impotence in Horace's Epodes", in Lowrie (ed.) 141-59.

Fraenkel, Eduard (1957) Horace (Oxford).

Francese, Christopher (2001) Parthenius of Nicaea (Frankfurt).

Gadamer, Hans-Georg (1975) Truth and Method (New York).

Gold, Barbara K. (ed.) (1982) Literary and Artistic Patronage in Ancient Rome (Austin).

Goldhill, Simon (2010) "Cultural History and Aesthetics: Why Kant is No Place to Start

Reception Studies", in E. Hall and S. Harrop (eds) Theorizing Performance: Greek Drama, Cultural History and Critical Practice (London) 56-70.

Gowers, Emily (ed.) (2012) Horace: Satires Book I (Cambridge).

Günther, Hans-Christian (ed.) (2013) Brill's Companion to Horace (Leiden).

Harrison, Stephen (2007a) Generic Enrichment in Vergil and Horace (Oxford). (ed.) (2007b) The Cambridge Companion to Horace (Cambridge).

Haynes, Kenneth (2006) "Text, Theory and Reception", in Martindale and Thomas (eds) 44-54.

Hinds, Stephen (1998) Allusion and Intertext (Cambridge).

Hobden, Fiona (2013) The Symposion in Ancient Greek Society and Thought (Cambridge). Holub, Robert C. (1984) Reception Theory: A Critical Introduction (London). 
Horsfall, Nicholas (1981) "Some Problems of Titulature in Roman Literary History", BICS

28.1: 103-14.

Hutchinson, G. O. (2008) Talking Books: Readings in Hellenistic and Roman Books of Poetry (Oxford).

Iser, Wolfgang (1978) The Act of Reading. A Theory of Aesthetic Response (Baltimore). Jauss, Hans Robert (1982) Toward an Aesthetic of Reception (Brighton).

Johnson, Timothy S. (2012 Horace's lambic Criticism. Casting Blame (lambikê Poiêsis) (Leiden).

Kennedy, Duncan F. (2006) "Afterword: The Uses of 'Reception"”, in Martindale and Thomas (eds) 288-93.

Kilgour, Frederick G. (1998) The Evolution of the Book (New York).

Lowrie, Michèle (1997) Horace's Narrative Odes (Cambridge). (ed.) (2009) Horace: Odes and Epodes (Oxford). (2009) "A Parade of Lyric Predecessors", in Lowrie (ed.) 337-55.

Lyne, R. O. A. M. (1995) Horace. Behind the Public Poetry (New Haven).

Mankin, David (ed.) (1995) Horace: Epodes (Cambridge).

Martindale, Charles (1993) Redeeming the Text. Latin Poetry and the Hermeneutics of Reception (Cambridge).

Martindale, Charles and Richard F. Thomas (eds) (2006) Classics and the Uses of Reception (Malden MA).

McNeill, Randall L. B. (2001) Horace. Image, Identity and Audience (Baltimore).

Morgan, Llewelyn (2010) Musa Pedestris. Metre and Meaning in Roman Verse (Oxford). Muecke, Frances (2007) "The Satires", in Harrison (ed.) 105-120.

Newman, J. K. (1967) The Concept of Vates in Augustan Poetry (Brussels).

Nisbet, Robin (2007) "Horace: life and chronology", in Harrison (ed.) 7-21.

Nisbet, Robin and Margaret Hubbard (1970) A Commentary on Horace: Odes Book I (Oxford).

(1978) A Commentary on Horace: Odes Book II (Oxford).

Nisbet, Robin and Niall Rudd (2004) A Commentary on Horace, Odes Book III (Oxford).

Oliensis, Ellen (1998) Horace and the Rhetoric of Authority (Cambridge).

Perris, Simon (2011) "Proems, Codas and Formalism in Homeric Reception", in Classical Receptions Journal 3.2: 189-212.

Porter, David H. (1987) Horace's Poetic Journey. A Reading of Odes 1-3 (Princeton).

Putnam, Michael C. J. (1995) "Design and Allusion in Horace Odes 1.6", in Stephen Harrison (ed.) Homage to Horace (Oxford) 50-64.

Rawson, Elizabeth (1985) Intellectual Life in the Late Roman Republic (London).

Renehan, Robert (1988) "Shackleton Bailey and the Editing of Latin Poetry: A Latin Classic. Q. Horati Flacci Opera" in CP 83.4: 311-28.

Rossi, Luigi (2009) "Horace, a Greek Lyricist without Music", in Lowrie (ed.) 356-77. Rotstein, Andrea (2010) The Idea of lambos (Oxford).

Rutherford, Richard (2007) "Poetics and Literary Criticism", in Harrison (ed.) 248-61.

Santirocco, Matthew S. (1986) Unity and Design in Horace's Odes (Chapel Hill).

Scodel, Ruth (2010) "lambos and Parody", in Clauss and Cuypers (eds) 251-266.

Watson, L. C. (2007) “The Epodes: Horace's Archilochus?”, in Harrison (ed.) 93-104.

Weinsheimer, Joel C. (1985) Gadamer's Hermeneutics. A Reading of Truth and Method

(New Haven). 
West, David (1995) Horace Odes I: Carpe Diem (Oxford). (1998) Horace Odes II: Vatis Amici (Oxford).

White, Peter (1982) "Positions for Poets in Early Imperial Rome", in Gold (ed.) 50-66. (1993) Promised Verse. Poets in the Society of Augustan Rome (Cambridge, Mass).

Whitmarsh, Tim (2006) "True Histories: Lucian, Bakhtin, and the Pragmatics of Reception", in Martindale and Thomas (eds) 104-15.

Wilkinson, L. P. (1968) Horace and his Lyric Poetry (Cambridge).

Williams, Craig A. (2012) Reading Roman Friendship (Cambridge).

Williams, Gordon (1982) "Political Patronage of Literature", in Gold (ed.) 3-27.

Wills, Jeffrey (1996) Repetition in Latin Poetry (Oxford).

Wiseman, T. P. (1982) "'Pete nobiles amicos': Poets and Patrons in Late Republican Rome", in Gold (ed.) 28-49.

Zetzel, James E. G. (1982) "The Poetics of Patronage in Late First-Century BC Rome", in Gold (ed.) 87-101. 